\title{
EVALUATION OF EXTERIORS
} Recong

HW- -26395

BY

R. S. DALRYMPLE

TECHNICAL SECTION ENGINEERING DEPARTMENT

MARCH 4, 1953
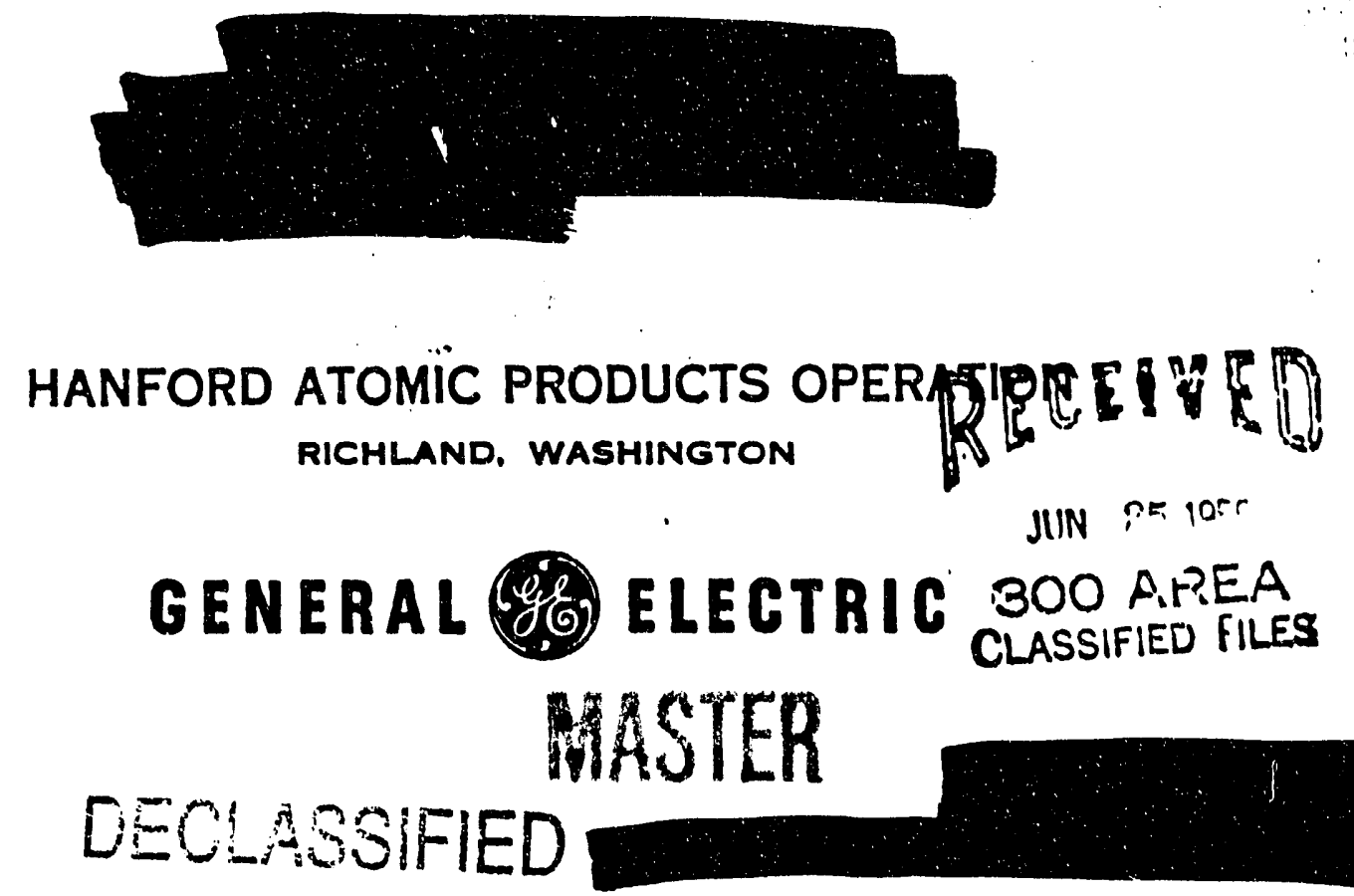


\section{DECLASSIFIED}

HW-26395

Metallurgy and Ceramic s

(B)

(

This document consists of 77 pages.

sonis of 1 ,

(a)

Uni-inisir

(1)

EVALUATION OF ANODIC FILMS ON PROCESS TUBE EXTERIORS

By

R. S. Dalrymple

New Fuel Unit

Fuel Technology Sub-Section
RECGiñ

Genem

$\operatorname{March} 4,1953$

\section{HANFORD ATOMIC QPRODUCTS OPERATION RICHLAND, WASHINGTON \\ (1)}

Operated for the Atomic Energy Commission by the General Electric Company under Contract W-31-109-Eng-52
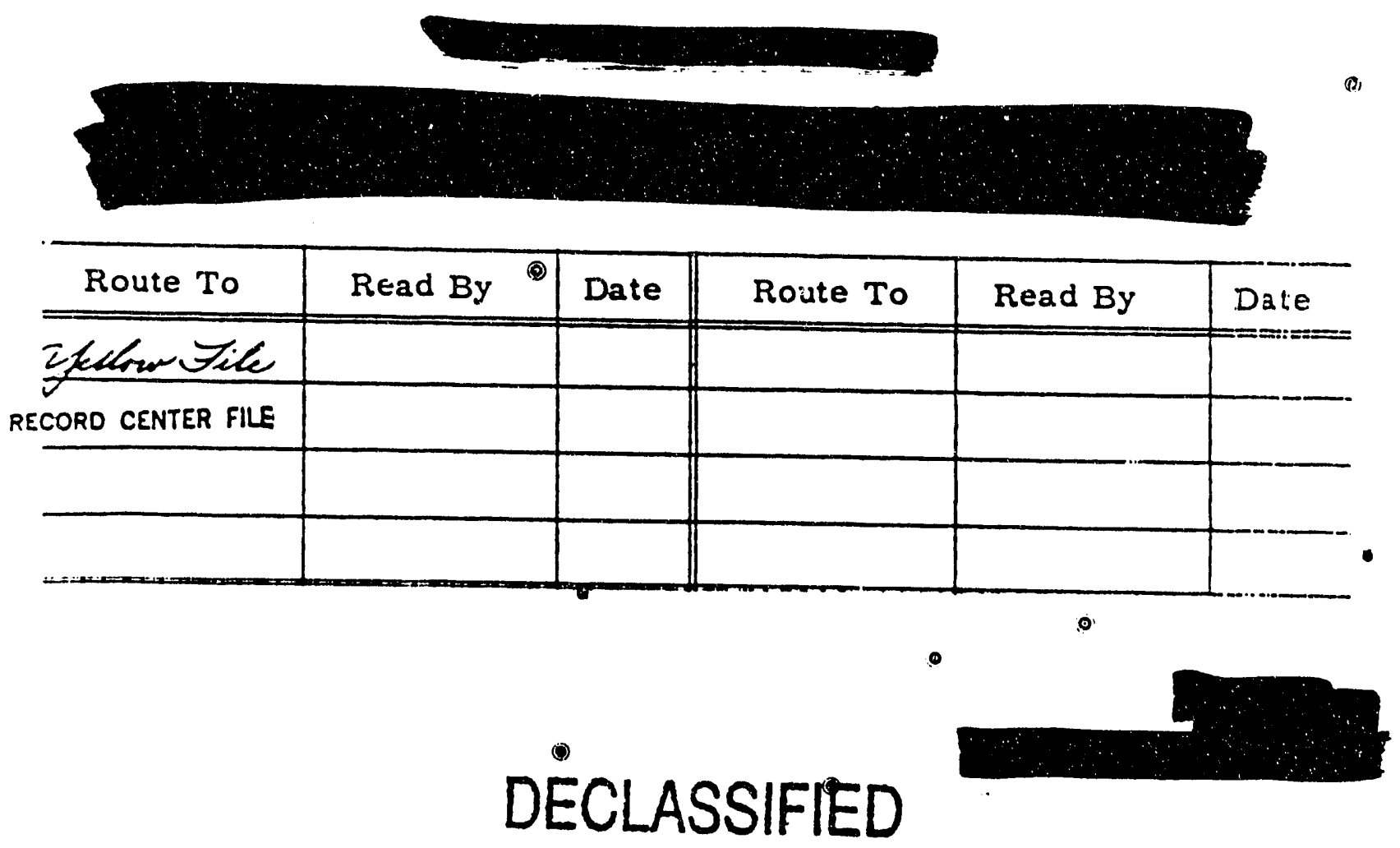


\section{DECLASSIFIED}

- -2-

\section{COPY NUMBER} 1 2
๑

๑

๑

๑

$\odot$
HW-26395

Metallurgy and Ceramics

\section{INTERNAL DISTRIBUTION}

F. W. Albaugh - J. J. Cadwell

J. A. Ayres

J. T. Baker

L. P. Bupp

A. H. Bushey

R. S. Dalrymple

W. R. DeHollander

B. R. Elder

O. H. Greager - W. K. Woods

A. B. Greninger

W. H. Hodgson

E. P. Lee

M. Lewis

W. R. Lewis

G. E. McCullough

R. O. Mehann - C. W. Botsford

J. H. M. Miller

S. L. Nelson

V. D. Nixon

E. W. O'Rorke

K. T. Perkins

E. C. Pitzer ๑

R. B. Richards - P. H. Reinker

R. A. Rohrbacher

G. M. Roy

K. L. Sanborn

W. L. Schalliol

๑)

F. A. R. Stainken - R. J. Bursey

L. D. Turner - R. G. Wheeler

R. Ward

J. H. Warren

300 File

700 File

Yellow Copy

우

๑

두

๑ 


\section{DECLASSIFIED}

$-3-$

HW-26395

Metallurgy and Ceramics

COPY NUMBER

- $35-42$

$43-47$

48

- $\quad 49-51$

52

53

$54-55$

$56-57$

$58-65$

$66-69$

70

71

$72-74$

$75-77$

78

$75-82$

83

$84-87$

$88-90$

91

92

$93-95$

- $\quad 96$

97

98

99

100

101

$102-106$

$107-109$

110

111

112

113

114

115

$116-119$

120

$121-124$

$120 \cdot 132$

(1)

$133-147$

EXTERNAL DISTRIBUTION

Argonne National Laboratory

A tomic Energy Commission, Washington

Battelle Memorial Institute

Brookhaven National Laboratory

Brush Beryllium Company

Bureau of Ships

California Research and Development Company

Carbide and Carbon Chemicals Company (K-25 Plant)

Carbide and Carbon Chemicals Company (ORNL)

Carbide and Carbon Chemicals Company ( $\mathrm{Y}-12$ Plant)

Chicago Patent Group

Dow Chemical Company (Rocky Flats)

duPont Company

General Electric Company (ANPP)

Hanford Operations Office

idaino Ope:alions Orfice

Iowa State College

Knolls Atomic Power Laboratory

Los Alamos Scientific Laboratory

Mallinckrodt Chemical Works

Massachusetts Institute of Technology (Kaufmann)

Mound Laboratory

National Advisory Committee for Aeronautics, Cleveland

National Advisory Committee for Aeronautics, Washington

National Bureau of Standards

National Lead Company of Ohio

Naval Research Laboratory

New Brunswick Laboratory

New York Operations Office

North American Aviation, Inc.

Patent Branch, Washington

RAND Corporation

San Francisco Operations Office

Savannah River Operations Office, Augusta

Savannah River Operations Office, Wilmington

Sylvania Electric Products, Inc.

University of California Radiation Laboratory

Walter Kidde Nuclear Laboratories, Inc.

Westinghouse Electrlc Corporation

Wright Alr Development Center

Technical Information Service, Oak Ridge

(1) 0 


\section{DECLASSIFIED}

\section{TABLE OF CONTENTS}

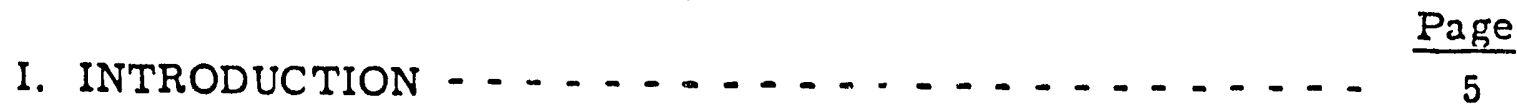

II. SUMMARY ....................... 6

III. CONCLUSIONS - . . . . . . . . . . . . . . 9

IV. OBJECTIVES - . . . . . . . . . . . . . . . 9

V. PROCEDURES AND RESULTS - . . . . . . . . . . . 9

VI. DISCUSSION OF RESULTS - . . . . . . . . . . . . 9

A. Preliminary Laboratory Tests .............. 9

1. Electrode Potential Measurements - . . . . . . . 9

2. Beaker Scale Galvanic Couple Tests _... . . . . 9

3. Graphite Block Tests - 3 Days Duration - . . . . . 10

4. Graphite Block Tests - One Week Duration - . . - 11

5. Elevated Temperature Corrosion Test Cell -.... 11

6. Effect of Dissolved Gases on Galvanic Corrosion - - 13

B. Evaluation of Anodic Films - . . . . . . . . . . 14

1. Anodic Film Evaluation at Room Temperature- - - 15

2. Anodic Film Evaluation at Elevated Temperatures - -19

VII. ACKNOWLEDGMENT _..................... 21

A PPENDIX

Part I: Laboratory Studies - . . . . . . . . . . 22

Part II: Coaling Procedures- . . . . . . . . . . . 72

ABSTRACT … . . . . . . . . . . . . 77 


\section{DECLASSIFIED}

$H W-26395$

\section{EVALUATION OF ANODIC FILMS ON PROCESS TUBE EXTERIORS}

\section{INTRODUCTION}

Corrosion on the exterfor of process tubes, resulting from contact with wet graphite, has been a serious problem in the nperation of F Pile. Since first noted, in early fall of 1951, the attack on the tube exteriors has become more pronounced, and the resulting corrosion product has caused the tubes to stick in the graphite channels. These sticking tubes present a costly problem because of time lost in renewal of leaking or stuck tubes and because of production losses resulting from capped-off channels.

As the seriousness of the problem became apparent, a metallurgical examination was conducted on tubes which were suspected of leaking or which were stuck in the channel blocks. The corroded sections of the tubes, or, if available, the entire tubes, were examined at the Radio Metallurgy Laboratory at 100-B Area for evidence of perforation and extent and severity of attack. Results of this examination have been previously reported. $(1,2)$

The investigation reported in this document concerns itself with studies of the mechanism of corrosion on the exterior of process tubes and with studies of the protective qualities of anodic films which might prevent corrosion on the exterior of process tubes. Sections of process tubing coated with Aqua-Dag, a colloldal graphite suspension, were included in these tests for comparison purposes. Fresent operatirg procedures call for the application of Aqua-Dag to the exterior of process tubes for lubrication purposes during the charging of tubes into the piles.

(1) R. S. Dalrymple, "Corrosion of Process Tubes from 100-F - Progress Report," HW-23343, January 28, 1952.

(2) D. L. Zimmerman, "Addition to Progress Report - Corrosion of Process Tubes from 100-F," HW-26334, November 21, 1952. 
Prior to completion of the room temperature evaluation and during the early stages of the tests at $90 \mathrm{C}$. Pile Technology Unit recommended that an in-pile test be performed to determine the usefulness of anodic films to reduce exterior corrosion on process tubes. The anodic film was applied by the Standard Alumilite Process and was not sealed (see Part II of the Appendix). $(3,4,5)$

\section{SUMMARY}

Severe corrosion on the exterior of process tubes in F Pile prompted a laboratory investigation into the causes of the attack and an evaluation of anodic films for diffusion barrites to corrosion.

The galvanic nature of the corrosion occurring on aluminum process tubes in contact with wet graphite was demonstrated by current flow measurements and electrode potential studies. It was also observed, in the beaker scale tests, that the type of attack was dependent on temperature. At low temperatures pitting attack predominated whereas at elevated temperatures generalized corrosion was observed.

- The investigation led to the construction of test units for evaluating and comparing protective coatings at room temperature and at $85 \mathrm{C}$ and $90 \mathrm{C}$. The three types of anodic coatings examined were: Standard Alumilite, Alumilite Hard Coating, and Martin Hard Coating. Non-coated control samples were included for comparison purpises.

Early favorable results from the room temperature test resulted in the coating of 200 process tubes (full length) for in-pile testing at F Pile.

(3) E. C. Pitzer, "Anodization of Process Tubes," HW-25656, September 17, 1952.

(4) R. S. Dalrymple and R. J. Bursey, "Trip Report - Anodizing of Process Tube Exteriors at Columbia Electric and Mfg. Co. , Spokane, Wash. ," HW-26469, December 4, 1952.

(5) R. M. Peekema, "The Anodizing of Process Tubes and Jacketed Slugs,." HW-26888, February 17, 1952. 


\section{DECLASSIFIED}

-

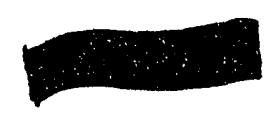

$-7-$

HW-26395

iil. CONCLUSIONS

The results of this set of experiments justify the following conclusions:

1. Corrosion on the exterior of process tubes within wet graphite blocks proceeds by galvanic attack, accompanied by both concentration cell corrosion and chemical solution. The galvanic attack apparently predominates and may proceed very rapidly, particularly if a cathodic depolarizer is present.

2. Application of the Standard Alumilite anodic film to the exterior of process tube sections greatly reduces galvanic corrosion both at room temperature and at $90 \mathrm{C}$, provided that the film is at least 1 mil thick. Sealing of the $1 \mathrm{mil}$ anodic film in either boiling distilled water or in boiling 5 per cent potassium dichromate solution increased the protective quality of the film.

The $1 / 4$ and $1 / 2$ mil Standard Alumilite films, sealed and unsealed, offered some protection against galvanic corrosion, but were subject to early deterioration resulting in localized penetrations and to the formation of mounds of corrosion product. These mounds of corrosion product may lodge the tubes into the graphite channels mechanically, by means of keying action, so that more force is required to rcmove tubez zrotected by thin anudic fiims than was required for non-protected tubes.

Penetration of the anodic films during the corrosion test invariably resulted in deeper pitting ihan that observed on non-anodized tube sections similarly exposed.

3. The $1 / 4 \mathrm{mil}$ protective and decorative anodic films applied by the chromic acid anodizing process were superior in performance to the $1 / 2$ and $1 / 4$ mil Standard Alumllite $111 \mathrm{~ms}$, but woro tnfor 60 s to the $1 \mathrm{mil}$ Standard Alumilite films. 


\section{DECLASSIFIED}

4. The 2 mil anodic film applied by the Martin Hard Coating process

- was superior to the anodic films applied by the Standard Alumilite and the Alumilite Hard Coating processes in the room temperature and $90 \mathrm{C}$ test, but was compa rable to them in the partial immersion test at $85 \mathrm{C}$. For this reason, the Martin Hard Coating process cannot be unqualifiedly recommended over the Standard Alumilite process or the Alumilite Hard Coating process for the application of barrier anodic films.

5. Anodic films applied by the Alumilite Hard Coating process offer corrosion barrier film properties comparable to sealed anodic films of the same thickness applied by the Standard Alumilite process.

6. Heating (200 C for 2 weeks, prior to corrosion testing) of process tube sections coated with anodic films applied by the Martin Hard Coating process, the Alumilite Hard Coating process, and the Standard Alumilite process had a variable initill effect on the protective value of the anodic films, rendering the Martin Hard Coating film less effective and increasing the protective value of the Standard Alumilite film and of the Alumilite Hard Coating film. The difference between the protective value of the heated and of the non-heated anodized samples decreased with increasing exposure to galvanic corrosion.

7. Non-protected process tubes may be safely loaded into dry graphite channels containing aluminum corrosion product without danger of initiating corrosion on the new tube surface. The addition of water to the channel will result in galvanic corrosion of the tube.

8. A coating of Aqua-Dag, or similar colloidal graphite suspensions, on nonoprotected process tubing promoted galvanic corrosion over and alsove that rosulting from contact of the tube with wet graphite. 


\section{OBJECTIVES}

This study was undertaken with two objectives: (1) to determine the mechanism of corrosion on the exterior of process tubes in contact with moist graphite; and (2) to evaluate anodic films as barriers to corrosion on the exterior of process tubes.

\section{PROCEDURES AND RESULTS}

Because of the large number of tests involved in this investigation, the engineering data and a detailed statement of results are included in Part I of the Appendix for those wishing details of the work.

\section{DISCUSSION OF RESULTS}

\section{A. Preliminary Laboratory Tests}

\section{Electrode Potential Measurements}

Electrode Potential Measurements between 2S aluminum and coupons of graphite machined from a channel block demonstrated the existence of a large voltage drop between the two materials, suggesting an electrochemical explanation for the attack observed in-pile. The voltage difference between aluminum and graphite was dependent on temperature, increasing from 0.58 volts at $20 \mathrm{C}$ to 1.22 volts at $77 \mathrm{C}$. The potential of the graphite electrode changed only slightly over the temperature range studied, whereas the potential of the aluminum electrode increased anodically by 0.64 volts over the temperature range.

\section{Beaker Scale Galvanic Couple Tests}

To determine the effect of temperature on the galvanic corrosion of aluminum coupled to graphite, a test was performed in which cougons of aluminum were coupled to equal areas of graphite in tap water at room temperature and at boiling. At room temperature, the corrosion rate of the aluminum as measured by weight loss was low, but pitting attack occurred, a maximum penetration of 7.3 mils being observed at 216 hours

\section{DECLASSIFIED}




\section{DECLASSIFIED}

exposure. Both weight loss and pit depth increased with exposure. At boiling, higher weight loss was experienced than at room temperature, out there was no evidence of pitting attack. Calculated from weight loss, the maximum penetration during the boiling water test was 0.44 mils at 127 hours exposure.

\section{Graphite Block Tests - 3 Days Duration}

The beaker type of test was informative as to the probable mechanism of corrosion on process tube exteriors but falled to duplicate the geometry found in-pile. The geometrical relationship between a process tube in a pile and the surrounding graphite channel block presents an ideal situation for oxygen concentration ceii (or otiner gaseous celij) corrosion which might occur simultaneously with galvanic attack. Thus, studies performed in beaker-type tests might given only a partial answer.

The first graphite block corrosion test consisted of a short length of process tubing contained within a section of graphite channel block wet with tap water at room temperature. Although the cluration of the test was only three days, the tube became firmly stuck within the channel block. Pitting attack had occurred, no general corrosion being noted. In conjunction with each pit was a mound of corrosion product.

The process tube and graphite block test was repeated, but at $6 \bar{C} \bar{C}$, ior an exposure period of three djys. As noted in the room temperature test, the process tube was stuck within the channel block by corrosion product formation. The tube was removed from the block after hammering, and, although there was no quantitative measurcoof the force required, there was no doubt that the tube from this elevated temperature exposure was more dificicult to remove than the one from the room temperature test. Corrosion on the tube exterior was severe and consisted of both general and pitting attack. The deepest plts occurred bonoath tho water inlets, The maximum pit depth belng 22 mils. Steam was employed to heat $t_{1}$ process tube, which in turn heated the graphite block. Temperature con: : is Inadequate.

\section{DECLASSIFIED}

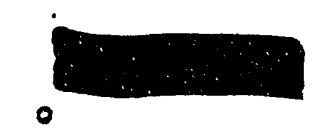




\section{DECLASSIFIED}

No provision had been built into the two preceding block tests for measuring galvanic currents. Without positive electrical contact between the tubes and the graphite blocks, the tube sections might become insulated from the block by corrosion product formation. In this event, corrosion on the tubes might suddenly stop, or, if the tubes continued to corrode, the cause would probably be concentration cell or crevice corrosion rather than galvanic attack. To obviate the possibility of reducing galvanic attack by forming an electrical insulating layer of corrosion product, subsequent tests units inciuded an external wiring circult assuring electrical continuity.

\section{Graphite Block Tests - One Week Duration}

To determine the effectiveness of an external electrical circuit, and to see if the previous room temperature and elevated temperature block tests could be duplicated, a series of three corrosion test assemblies consisting of process tube sections in graphite channel block sections were placed in test at temperatures of $15 \mathrm{C}, 55 \mathrm{C}$, and $80 \mathrm{C}$. Because of repeate $i$ failures in the external circuit, galvanic current flow was demonstrated but not routinely measured.

At the end of 168 hours exposure, the tube section from test at $80 \mathrm{C}$ was firmly stuck within the channel block, 177 pounds of force being required to remove it. Tube sections exposed at $15 \mathrm{C}$ and $55 \mathrm{C}$ were not stuck. Both pitting and general attack had occurred on the samples. the most severe attack occurring at $80 \mathrm{C}$, the least severe at $15 \mathrm{C}$.

\section{Elevated Temperature Corrosion Test Cell}

It was obvious from the preceding tests that steam heating of the block assemblies was far from the ideal method for obtaining controlled elevated temperatures. Not only was temperature control difficult, but corrosion on the interior of the aluminum tube section, resulting from contact of the tube with steam and steam condensate, introduced unknown - weight changes.

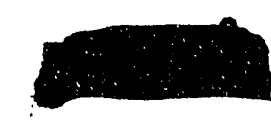


Electrical heating was chosen for the elevated temperature tests, the heat being furnished by cartridge-type electrical heaters. In the test assembly finally developed, four cartridge heaters were employed, one in each of the fisur corners of a four-inch cubical channel block. The resistance heater units were connected in parallel to a variable transformer. Temperature conirol was maintained by varying the heater voltages.

(0)

To evaluate the proposed method of heating. a tube section was mounted within a four-inch channel block section equipped with four cartridge heaters. Thermometer holes had been drilled into various locations in the block so that the uniformity of block temperature could be determined. The process tube section was connected to the hlock through a 10-ohm resistor, providing a means for measuring galvanic current - flow. Temperature measurements indicatéd a high degree of uniformity throughout the graphite block. The block temperature was affected by variations in the room and water temperature and by water flow rates.

Galvanic current now measurements were obtained throughout the 148-day test. The amount of current generated by the galvanic couple was more than that observed for galvanic couples at room temperatures (see that section of the Discussion concerning evaluation of barrier films).

After temperature control had been demonstrated, the water supply was turned off, meanwhile maintaining a block temperature of $90 \mathrm{C}$. In a matter of hours the galvanic current flow diminished from 1250 microamperes to essentially 0 microamperes. Turning on the water causpd an instantaneous return of the galvanic current. This cycle was repeated several times with similar results.

Measurement of the galvanic current during the dry periods disclosed the presence of stray currents from the cartridge heaters. The magnitude of these induced currents was very low, approximately 0.1 microamperes per square foot of exposed process tubing. Replacement 


\section{DECLASSIFIED}

$-13-$

$\mathrm{HW}-26395$

\section{(c) 9}

of the wire-wound precision resistor in the current monitoring circuit with a non-inductive resistor lowered the induced curfents to insignificant values.

())

Corrosion on the sample exposed in this elevated temperature lest consisted of both pitting and general attack, the most severe pitting occurring at or near the water inlet and the maximum pit depth being 35 mils. Corrosion was so severe at this site that the inner diameter of the process tube was reduced by seven mils as a result of corrosfon product for ria'ion.

6. Ceffect of Dissolved Gases on Galvanic Corrosion

Electrode potential studies were begun to determine the effects of dissolved gases on galvanic couples. The preliminary results of these tests indicated the following: $(6,7)$

1. In water saturated with air, the aluminum-graphite couple is under mixed control; that is, the reactions at both the anode and cathode control the amount of galvanic corrosion.

2. In oxygen-saturated water, the reaction was cathodically controlled.

3. In helium-saturated water, the reaction was under cathodic control, but galvanic corrosion was not as severe as that noted in oxygen-saturated water because the aluminur, and graphite electrodes polarized to the same potential at a much lower current density than that observed in oxygen-saturated water.

4. Afon dioxide aeration permitted rapid polarization of both the aluminum and graphite electrodes to the same potential at very low current densities. Rapid polarization at low current density

(6) E. C. Pitzer. "Technical Activities Report - Corrosion, June 1052," $H W=2483 \theta$.

(7) E. C. Pitzer, "Technical Activities Report - Corrosion, July 1952," HW- 26058 . 
0

r.

would be expected in $r$ -

That carbon dloxide aed, "ireduced rates of galvanic corrosion. .1 does reduce galvanic corrosicn of aluminum when coupled to graphite was demonstrated by comparison of weight-loss data for aluminum samples coupled to graphite coupons in water both with afd without aeration with carbon dioxide. ${ }^{(8)}$

These data indicate that the results of galvanic corrosion tests betwcen aluminum and graphite and between aluminum and stainless steel, previously reported by Loftness and Chrisney ${ }^{(9)}$ may be considerably low because of the carbon dioxide aeration employed in the experiments.

B. Evaluation of Anodic Films

())

During the study of the mechanism of process tube corrosion and during development of 'suitable test equipment, conside;zton was given to possible means of reducing corrosion on process tube exteriors. Inhibitors for the gaseous atmosphere in the pile were considered 9 mpractical, not only because of the amount of inhibitor likely to be required but also because of the as-yet-unknown effects of pile operation on inhibitors.

Barrier films, such as paints and greases, would probably break down under pile operating conditions, rendering them useless to prevent cofrosion. One type of barrier film, a vallable for use on alyminum, which has good nuclear properties, is chemically stable, and which required only a moderate amount of development, is aluminum oxide applied-by anodic oxidation.

The most common anodic films, for both protective and decorative purposes, are applied at room temperature in a 15 per cent sulfuric

(8) E. C. Pitzer, HW-24839.

(9) R. L. Loftness and J. B. Chrisney, "The Galvanic Corroston of Aluminum-Steel and Aluminum-Graphite Couples as a Function of Water Composition and Temperature," NAA-SR-133, 9-24-52. 
acid solution. There are many modifications of the coating technique which result in heavier and/or more dense f'lms which may exhibit greater resistance to abrasion or corrosion or both. Most of these films, and all of those tested in this investigation, are patented by the Aluminum Company of America. For a description of the coatingechniques see Part II of the Appendix.

\section{Anodic Film Evaluation at Room Temperature}

A galvanic couple test of short duration was performed at room temperature to compare process tube sections geated with Standard Alumilite with an unprotected process tube section. Three coating thicknesses $(1 / 1 / 2 \mathrm{mil}, 1 / 2 \mathrm{mil}$, and $1 \mathrm{mill})$ and three sealing conditions (unsealed, water-sealed, and dichromate-sealed) were filcluded in this test.

Galvanic current flow measurements were obtained during the course of the test and indicated that the non-protected sample was corroding at a much higher rate than were the anodized samples. Of the a nodized samples those coated with $1 \mathrm{mil}$ and $1 / 2 \mathrm{mil}$ films were markedly superior to the samples coated with $1 / 4 \mathrm{mil}$ films, regardless of sealing treatment. Current measurements indicated that the protective qualities of Standard Alumijite decreasedyith increasing exposure. The loss in protective value is probably explained by the dissolution of the anodic fifin during exposfre to water.

\section{(c)}

- Compared"with unsealed anodic films, sealing reduced the effectiveness of the $1 / 4 \mathrm{mil}$ film to minimize galvanic corrosion but increased the protective value of the heavier coatings. The dichromate seal had little effect on $1 / 4 \mathrm{mil}$ anodic fjlm, and increased the effectiveness of the $1 / 2 \mathrm{mil}$ and one mil anodic films.

- Upon completion of this test, after 29 daj's exposure, all but three of the anodized tube sections were stuck within the gannel blocks. The three lot stuck were: $1 / 2 \mathrm{mil}$, water-sealed; $1 \mathrm{mil}$, water-sealed; and o:

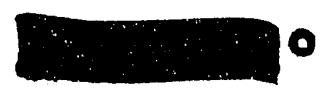


$s$

\section{DECLASSFFIED}

$-16-$

(a)

HW-26395

1 mil, dichromate-sealed. The remaining stgck tubes were discharged, using a Baldwin Tensile Machine to apply and measuge the force required. The unprotected tube required the most force for removal, approximately 60 pounds. Of the anodized samples which stuck, those with $1 / 4 \mathrm{mil}$ films required up 050 pounds for discharge, those with $1 / 2 \mathrm{mil}$ films up to 30 pounds, and the only 1 mil sample stuck required 12 pounds.

a

After removal of the tube sections from the graphite blocks, the

$O$ corrosion product and the remaining anodic film were dissolved in $a$ chromic acid-phosphoric acid solution, and the tubes were examined.

The non-protected sample had undergone the most severe pitting attack of any of the samples. The deepest pitting occurred at the water inlet, at which site a maximum pit depth of 24 mil( ) was measured. The remainder of the surface of this sample from within the channe block had also been pitted, but the depth of attack was much less. (-)

With the exception of the $1 \mathrm{mil}$ dichromate-sealed film, the anodic films had undergone localized breakdown resulting in pitting of the prucess tube sections The dcpth of the attack, both maximum and ayerage, was about the same in those samples on which the anodic films failed ( $4 \mathrm{mils}$ average and $8 \mathrm{mils}$ maximum). The number of pits was least for the one mil samples, and greatest for the 1 mil films.

(8) Because the $1 / 2 \mathrm{mil}$ and $1 \mathrm{mil}$ anodic films were effective in reducing the amount of galvanic corrosion on process tube sections for a period of one month, a longer test was begun. Two samples of each anodic film thickness and sealing treatment, one sample of which was scratched Ohrough the aluminurn oxide film, were included in the test.

For comparison, 8 non-protected tube sections were included. Six of these samples were removed from the test after increasing exposure perlods; the force required to loosen the tubes in the channel bloclis was measured. The two remaining sampleswere coated with Aqua-Dag,
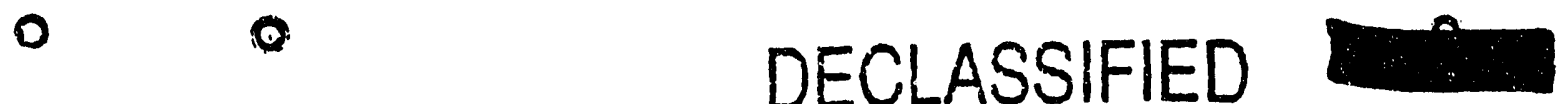


\section{DECLASSIFIED}

a7- 0

HW-26395

a colloidal graphite suspension normally applied to process tubeg as a. lubricant prior to charging into the plle.

Initially, the non-protected samples corroded galvanically at a high ra!e which reduced to a steady lower rate after 40 days exposure. Weight losses calculated from galvanic curfent flow corresponded to approximately 2.5 milligrams per day during the period of more-or-less constant rate. Weight losses from galvanic current flow for the samples coated with Aq:la - Dag a veraged 1.9 milligrams per day during the period of constant corrosion rate. The measured weight losses were higher for the samples coated with Aqua-Dag than for the non-coated samples. Local galvanic corrosion between the process tube and the graphite purticles in the AquaDag film probably accounted for th:e difference.

Attack on the non-proiected tubes consisted of both localized and general corrosion, the amount and severity of attack increasing with increasing exposure. The maximum pit depth was greater for the samples coated with Aqua-Dag then for thehon-coated samples, $O_{30}$ mils compared to 12 mils, the most severe attack occurring at the water inlet. Two factors are belleved to have contributed to the locallzation of severe attack to the water inlet. The firsi factor was the redugtion of water flow to the bulk of the tube section by corrosionproduct formation and the deposition of water Borne salts and solids. The second factor was the depolarizingaction of dissolved oxygen acting on the graphite cathode.

Measurements indicated that the force required to loosen the nonprotected tube sections in the channel blocks was an increasing function

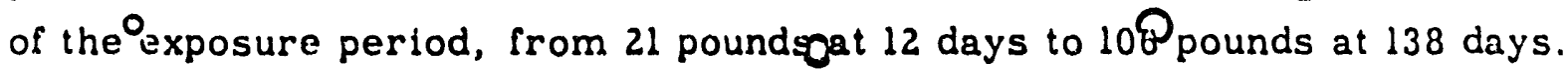

As measured by galvanicgurrent flow, the application of anodic films reduced galvanic corrosion on tube sections, the 1 mil films being more effective than the $1 / 2 \mathrm{mil}$ films. Penetration of the protective layer by scritching reciuced but dig not elinninate the value of the films. As the o

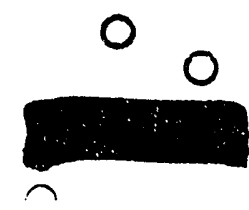




\section{DECLASSIFIED}

$-18-$

$H W-26395$

exposure period increased, the anodic films decreased in effectiveness. In the case of the unsealed films, the loss in protective value resulted from dissolution of the anodic film. The sealed films failed locally, not being appreciably dissolved.

The depth of pitting was greater on the Alumilite samples compared with non-coated tubes by a factor of 2 , an average pit depth of 8 mils being observed for the non-protected sample as compared with 16 mils for the anodized samples. The number of pits was considerably less on the anodized samples, particularly on the samples coated with 1 mil of Alumilite.

- Only on the basis of current flow, do the samples coated with $1 / 2$ mil of Alumilite compare favorably with the non-protected samples. At the end of the test, after 134 days exposure, the force required to remove the tubes coated with $1 / 2 \mathrm{mil}$ Alumilite was a minimum of 533 pounds and a maximum of 1340 puunds, compared to maximum value of 106 pounds for the non-protected samples, 334 pounds for the samples coated with AquaDag, and 46 pounds for the $1 \mathrm{mil}$ anodized samples.

The large force required to loosen the tubes coated with $1 / 2 \mathrm{mil}$ Alumilite may be explained by the keying action of the numerous mounds of corrosion product growing out of breaks in the anodic film. The nonprotected samples were more uniformly attacked, resulting in early stoppage of the water path by corrosion product formation Inaccessibility to water prevented formation of a sufficient quantity of corrosion product to bind the tube into the shannel block to the extent that the numerous mounds of corrosion product associated with the $1 / 2 \mathrm{mil}$ film were capable of doing.

The effect of sealing treatment was most obvious from the visual examinations and from the measured weight loss. The $1 / 2$ and $1 \mathrm{mil}$ unsealed samples lost more weight during the test than did the sealed anodic films, very much more weight than was indicated from galvanic current flow. 'Thls welght loss rellected a higher solubillty for the . 


\section{DECLASSIFIED}

$-19-$

HW-26395

unsealed anodic films. The unsealed film on the $1 / 2 \mathrm{mil}$ samples had dis solved sufficiently to expose bare metal. The 1 mil unsealed film was nearly, but not quite, penetrated. The sealed films had dissolved slightly, but not as extensively as the unsealed films.

\section{Anodic Film Evaluation at Elevated Temperatures}

In addition to the Standard Alumilite anodized samples evaluated at room temperature, the $90 \mathrm{C}$ test included tube sections anodized by the Martin Hard Coating process, Alumilite Hard Coating process and the chromic acid anodizing processes. For comparison, non-protected process tube sections were inc'uded. Two samples of each type of anodic coating wera included in the test, one of which was scratched along the long axis of the sample to penetrate the protective film.

Current flow measurements indicated that galvanic corrosion rates for the non-coated samples were about 50 per cent higher at $90 \mathrm{C}$ than at room temperature. The non-coated samples suffered increasing weight losses with increasing exposure, both general and pitting attack being present. Application of Standard Alumilite anodic films, $1 / 2 \mathrm{mil}$ and 1 mil thicknesses, reduced the galvanic current flow cumpared with the non-protected samples.

The chromic-acid anodized samples, both the decorative and protective coatings, performed remarkably well considering that the film thickness was only $1 / 4 \mathrm{mil}$. The chromic-acid coatings were increasingly protective during the first 45 to 50 days of the test, and then began to break down and to allow the passage of increasing amounts of current. Visual examination indicated that the breakdown was the result of solution of the films during exposure.

o.

On the basis of current flow measurements, the sample of Alumilite Hard Coating exhibited protective qualities comparable with the sumple of standurd Alumblite of the same thickness. Anodic films applied by the Martin Hard Coating process were markedly superior compared to the other anodic films.

(3)

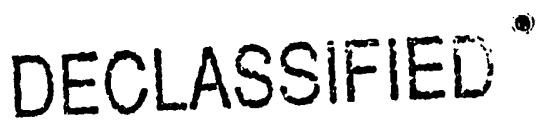




\section{DECLASSIFIED}

$-20-$

-

HW- 26395

To determine if prolonged heeting of anodic fllfis at temperatures approximating those found in-pile would reduce or destroy their protective value in galvanic couple, samples of Standard Alumilite $(1 \mathrm{mil})$. Alumilite Hard Coating ( 2 mils) and Martin Hard Coating $(2 \mathrm{mils}$ ) were heated at $200 \mathrm{C}$ for a period of two weeks. There was no visual change in the appearance of the films, but microscopic examination revealed checking and cracking. The most severe cracking occurred on the samples of Martin Hard Coating. The heated samples, non-heated samples, and a non-coated control were tested in channel blocks partially immersed in pile-filtered $\odot_{\text {water at }} 85 \mathrm{C}$ and at low flow rate. Entry of water to the interior of the ${ }^{\circ}$ process tubes was prevented by closing off the bottom end of the sample by means of a rubber stopper. There existed an area at the bottom of the tube section which was not adequately protected by the anodic fllm and which was not protected by the rubber stopper. Because of this, and because the procedure employed to evaluate the effects of heating constituted an accelerated type of testing aimed at comparing the effects of the heating of anodic films, conclusions based on this test concerning the protective qualities of the several anodic films are to be considered neither final nor amenable to extrapolation to the in-pile envifonment.

Current flow measurements indicated that heating had a definite initial effect on the protective value of the three types of film, but that the diffurences in current fluw between heated and non-heatedecoated = tubing reduced with increasing exposure.

Heating of the tubes coated by the Martin Hard Coating process $\infty$ Peduced the protectife value of the anodic $f 11 \mathrm{~m}$. Heating of the Alumilite Hard Coating and Standard Alumilite fllms reduced current flow, although this advantage decreased with extended exposure. Measurement of the force required to loosen the tubes in the channel blocks bore out the currunt flow data; tfut is, more force was reguired to loosen those tubes uxhibiting the higher current measurements. Visual examination of the 


\section{DECLASSIFIED}

coated samples revealed that the coating fallures were very localized in nature, the greatest number of penetrations being observed on those samples which exhibited the highest current flow and also which required the most force to loosen the tubes in the channel blocks. The pit depth measurements indicated uniform depth of pitting on all coated samples, the attack being considerably deeper than that observed on the non-protected samples.

VII. ACKNOWLEDGMENT

The collection and analysis of the information reported in this document was made with the assistance of W. B. Nelson.

0

(๑)

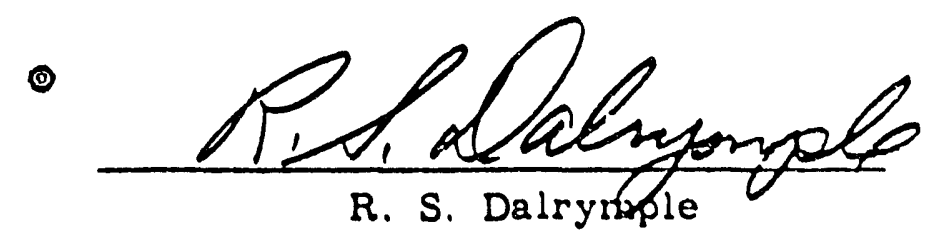

RSD:1j

(1)

$\bullet$ 


\section{DECLASSIFIED}

$-22-$

HW -26395

APPENDIX

0

Part 1: Laboratory Studies

Test 1: Solution Potential Measurements

0

Description:

Individual samples of $2 S$ aluminum and graphite, from a channel block, were immersed in flowing pile process water at $100-5$ Area at temperatures of $20 \mathrm{C}, 60^{\circ} \mathrm{C}$, and $78 \mathrm{C}$. Prior to the test, the aluminum samples were abraded to a uniform appearance using No. 120 grit aluminum oxide abrasive paper.

Results:

During a 3 hour exposure, the electrode potentials of the two materials approached a constant value. Figure 1 contains the electrode fotential values for aluminum and graphite after 3 hours' exposure, referred to the saturated calomel electrode. The potentials contain the appropriate temperature corrections. The potential difference between aluminum and graphite at the three temperatures is afso shown.

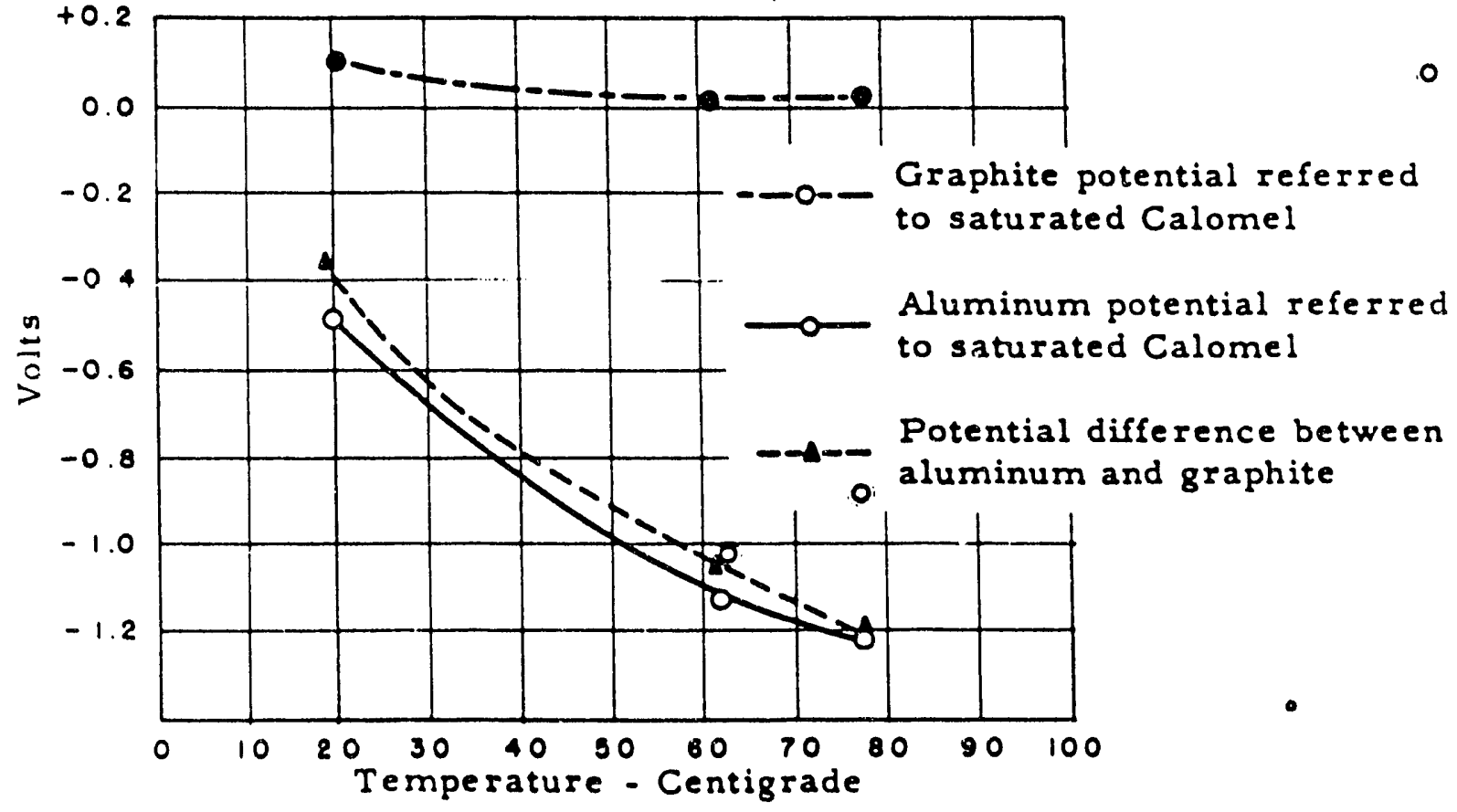

ELECTRODE POTENTIALS OF $2 S$ ALUMINUM AND GRAPHITE. IN PILE PROCESS WATER - - 3 HOURS EXPOSURE FIGURE 1 


\section{DECLASSIFIED}

-

Test 2: Corrosion of Aluminum Coupled to Graphite Description:

Individual samples of aluminum and graphite (equal areas) for eàch exposure period were galvanically coupled and $1 \mathrm{mmersed}$ in tap water at either room temperature or boiling. Cold finger condensers were employed at the boiling temperature to prevent excessive water losses. The water was not changed during the test, but make-up water was added as needed. Prior to the start of the test, the aluminum coupons were measured, degreased in acetone, and weighed. After completion of the test, which extended for 216 hours at room temperature and 144 hours at boiling, the aiuminum coupons were visually examined, then cleaned in chromic acidphosphoric acid solution (ste Part II of the Appendix), and weighed.

Results:

Table band Figures 2 and 3 contain the results of the test.

Test 3: Process Tube Section in Graphite Channel Block - Room Temperature

6

Description:

A short section of process tubing, approximately 6 inches long, was degreased in acetone, then suspended vertically in a 4 -inch section of graphite channel block. Tap water was used to moisten the galvanic couple. No external electrical connection was made between the tube section and the graphite block. The exposure period was 3 days.

Results:

At the end of the test, the tube section was firmly stuck within the channel block. Several sharp hammer blows were required to loosen the tube for removal. Corrosion consisted of scattered pitting attack only. No pit depth measurements were obtained. 


\section{DECLASSIFIED}

$-24-$

$H W-26305$

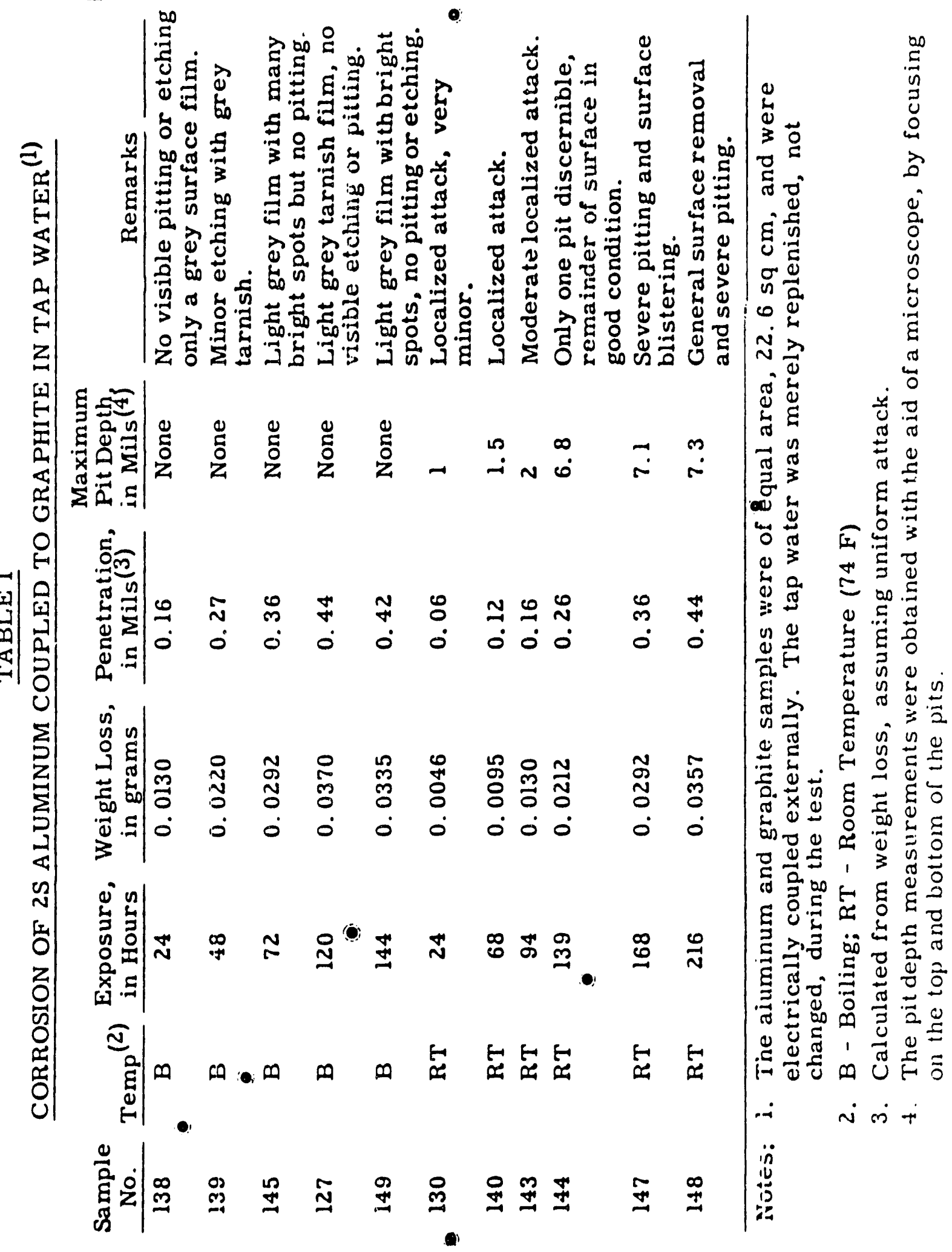

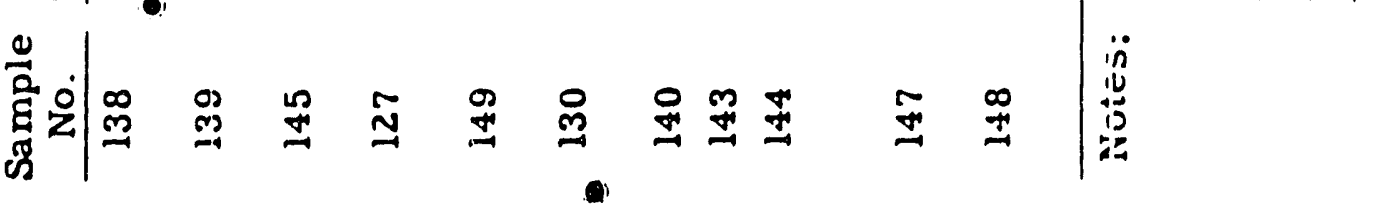




\section{DECLASSIFIED}

25.

HW -26395

CORROSION OF 2S ALUMINUM COUPLED TO GRAPHITE IN TAP

WATER AT THE INDICATED TEMPERATURES AND EXPOSURE PERIODS.

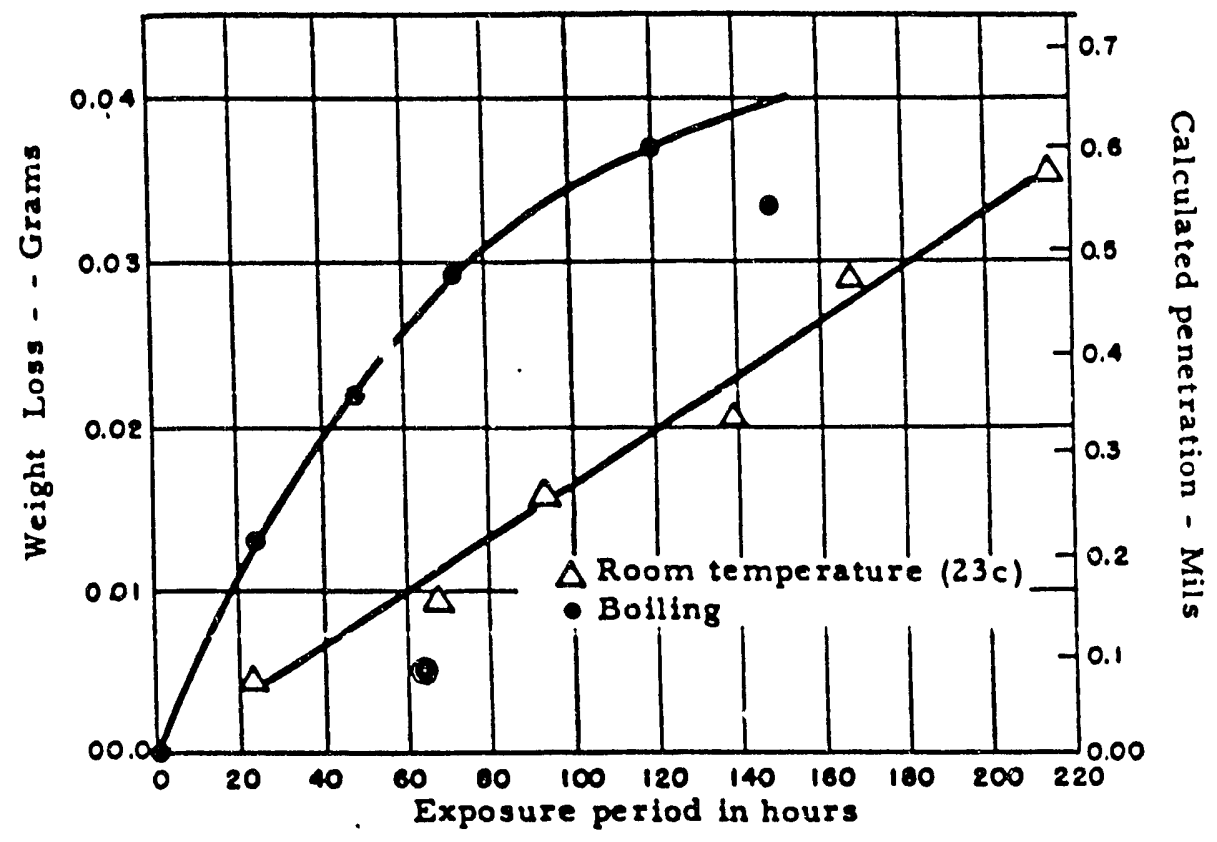

Figure No. 2

MAXIMUM PIT DEPTHS ON SAMPLES OF $2 S$ ALUMINUM

COUPLED TO GRAPHITE AT ROOM TEMPERATURE

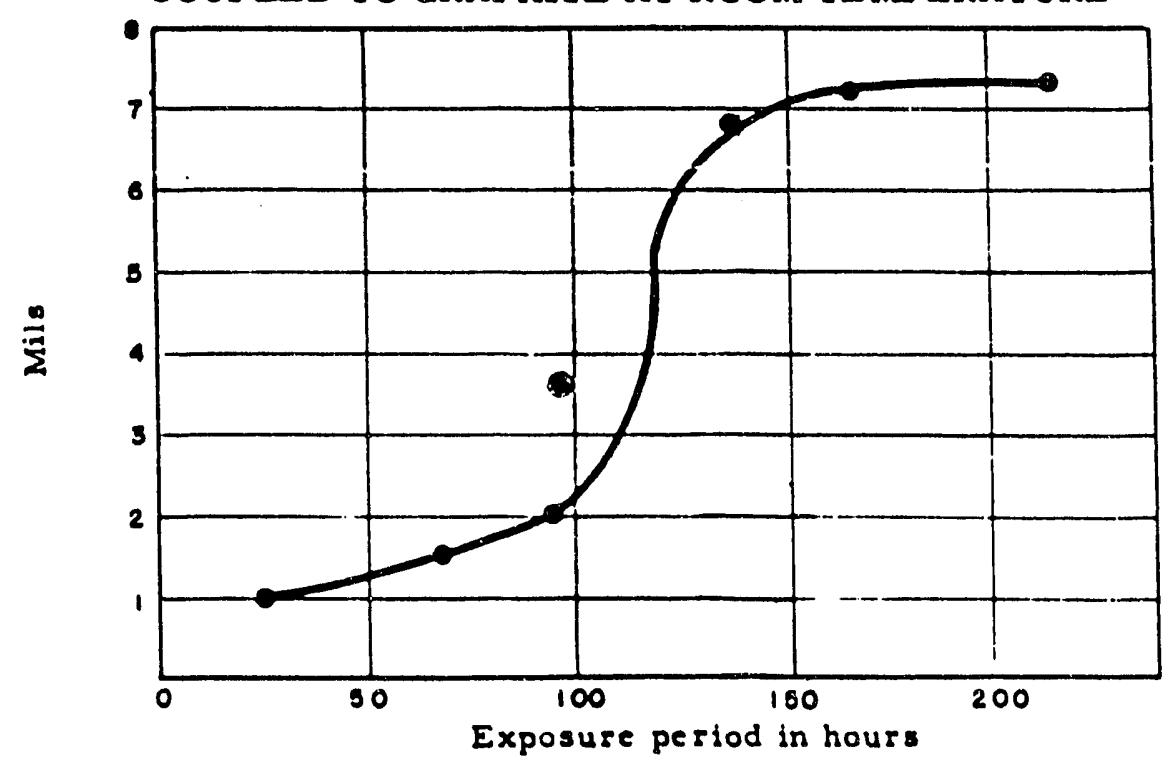

-

Figure No. 3 


\section{DECLASSIFIED}

Test 4: Process Tube Section in Graphite Channel Block - Elevated Temperature

Description:

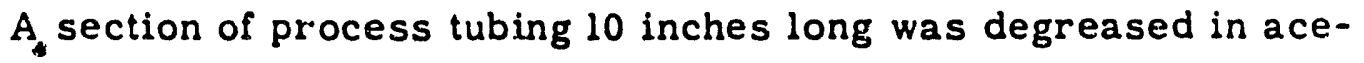
tone and was mounted horizontally in an 8-inch section of graphite channel block. The test assembly was heated to about $65 \mathrm{C}$ by passing steam into the interior of the tube section. Figure 4 illustrates a similar set-up. Tap water was introduced into the annulus surrounding the process tube through a series of holes drilled into the graphite. No external electrical connections were made between the process tube and the channel block. Duration of the test was 3 days.

Results:

At the end of the test period, the tube section was stuck within the channei block, several hammer blows being required to loosen the tube sufficiently to allow removal. The tube had undergone severe corrosion, both general and pitting attack being noted. The maximum pit depth, measured by means of a microscope, was 22 mils. The deepest pits occurred beneath the water inlet holes. Metallographic examination of sections taken through corroded portions of the process tube revealed that the general attack was only superficial. Slight attack had occurred on the tube interior, as a result of contact with steam condensate.

Test 5: Process Tube Section in Graphite Channel Block - 15 C, 55 C, and $80 \mathrm{C}$

Description:

Figure 4 is a photograph of one of the test assembiies employed in this test. Heat was supplied by passing steam through the interior of the tubes. Water was supplied through the holes shown in the top of the graphite block. The process tube sections were electrically connected to the graphite blocks externally. The external electrical circuit contained 


\section{DECLASSIFIED}

$-27$.

HW -26395

Figure 4

CORROSION TEST UNIT FOR TEST NO. 5.

The pitted portion of the tube was within the graphite channel blocka during the teat.

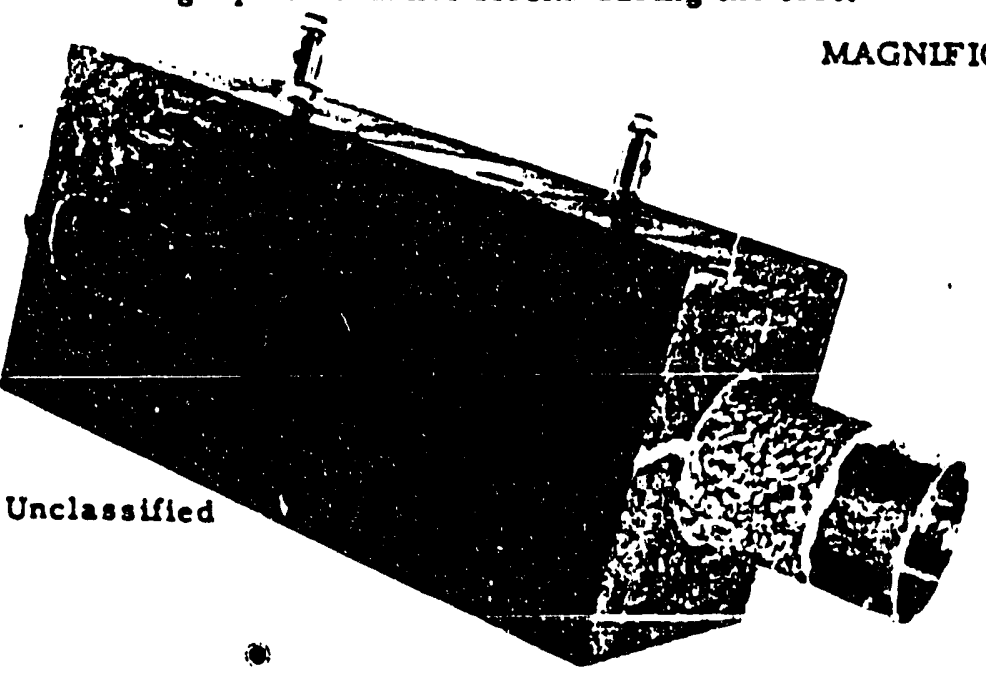

Figure 5

SECTION OF PROCESS TUBE AFTER EXPOSURE IN A GRAPHITE CHANNEL BLOCK FOR 168 HOURS AT 15C (NOT DE-SCALED)

The unattacked Section at the left was exposed to air the corroded section was in the block.

Unclassified

MAGNIFICATION $1.7 \mathrm{X}$

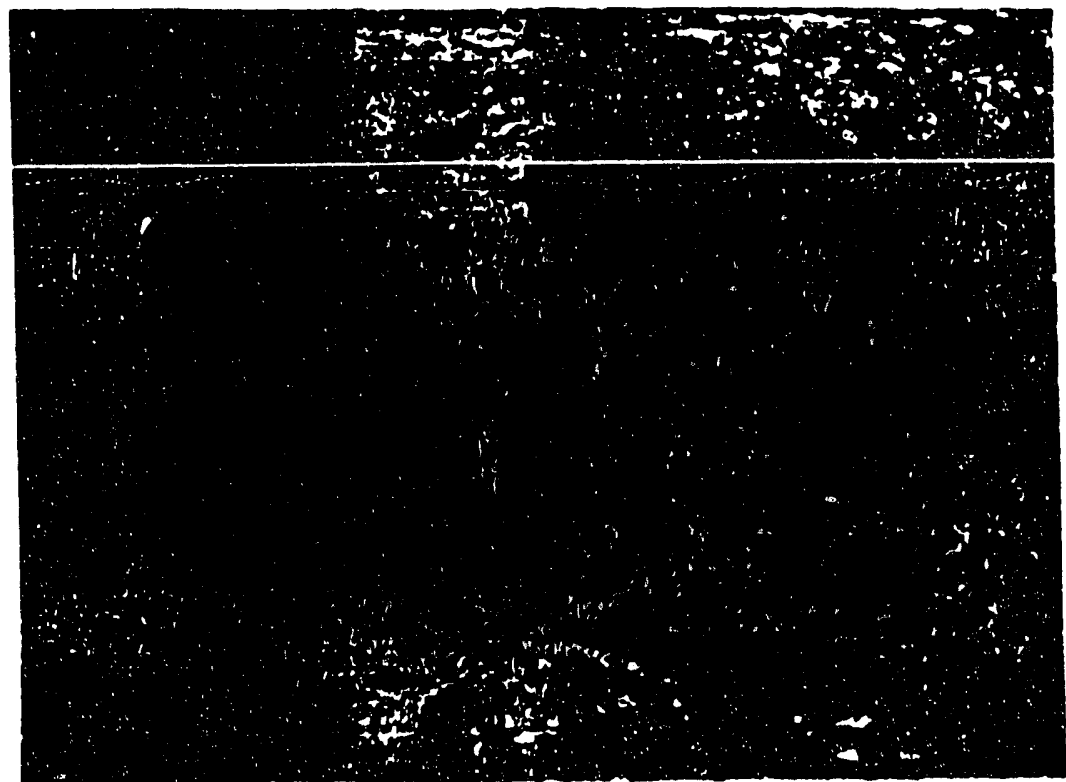

\section{DECLASSIFIED}




\section{DECLASSIFIED}

a $10 \mathrm{ohm}$ resistor which, in conjunction with a suitable voltmeter, made it possible to measure galvanic current flow during the test. The test duration was 168 hours. Prior to the test, the tube sections were degreased in an alkaline cleaner to a water break-free condition.

Results:

Because of failure of the electrical wiring, it was not possible to obtain routine current flow measurements. Current flow was demonstrated for the test-sample at $80 \mathrm{C}$, and was 4 milliamperes at 168 hours exposure. At the end of one week's exposure the $80 \mathrm{C}$ sample was firmly stuck within the two channel block sections. The force required to loosen the tube from the block was measured on a Baldwin Tensile Machine to be 177 pounds. The two process tube sections at the lower temperatures, $15 \mathrm{C}$ and $55 \mathrm{C}$, were not stuck in the blocks.

The appearance of the uncleaned samples is depicted in Figures 5 , 6, and 3. At all temperatures, both pitting and general attack occurred; the severity of attack increased with increasing temperature.

After the visual examination, the samples were de-scaled in chromic acid-phosphoric acid solution (See Part II of the Appendix), and pit depth measurements obtained. Maximum pit depths on tubes exposed at the three temperatures were:

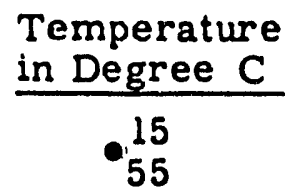

80
Maximum Pit Depth, In Mils

Test 6: Effect of Anodic Films on Galvanic Corrosion of Aluminum Coupled to Graphite - Room Temperature

Description:

This test, the first employing anodic films as barriers to corrosion, was conducted at room temperature. Three types of anodic film and throe

\section{DECLASSIFIED}




\section{DECLASSIFIED \\ $-29$.}

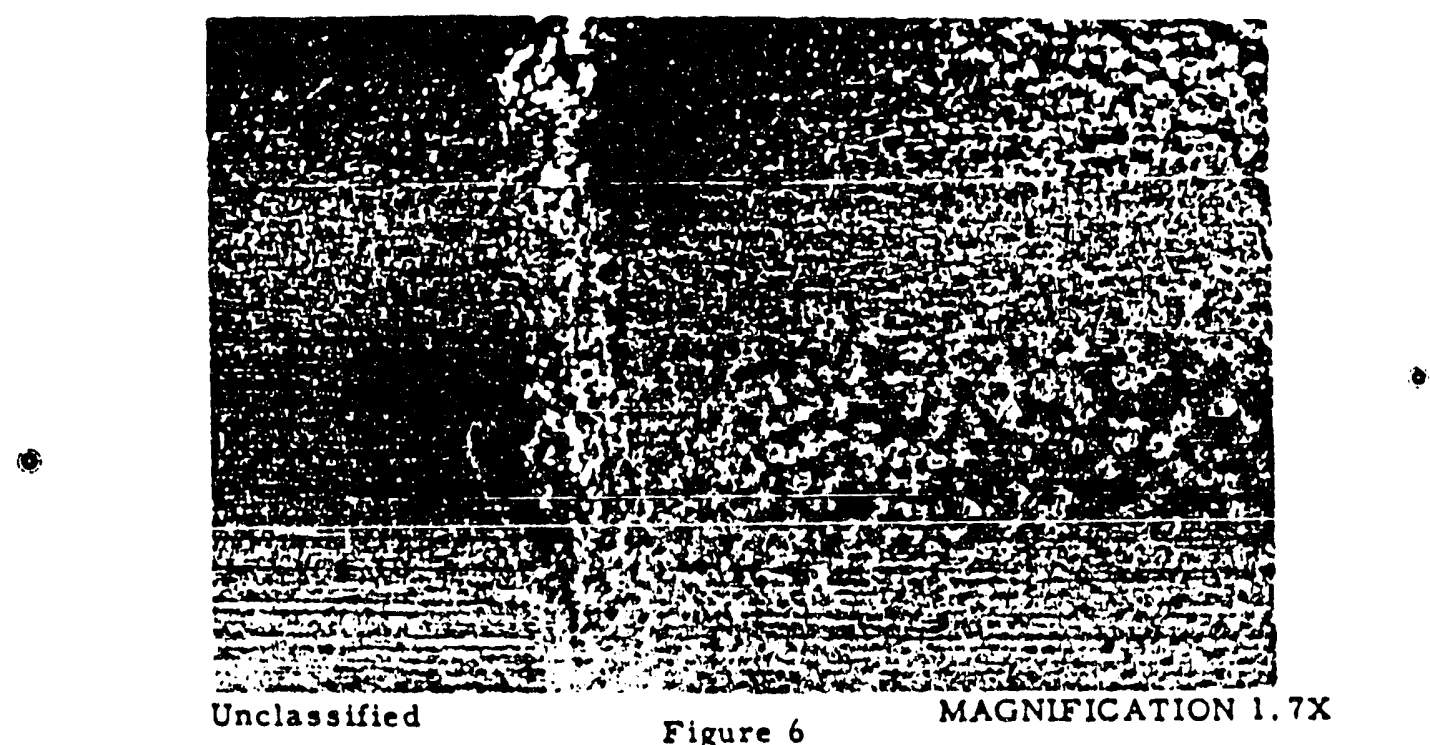

SECTION OF PROCESS TUEE AFTER EXPOSIRE IN A GRAPHITE CHANNEL BLOCK FOR 168 HOURS AT 55C (NOT DE-SCALED).

The unattacked section at the left was exposed to air. the corroded section was in the Graphite Block.

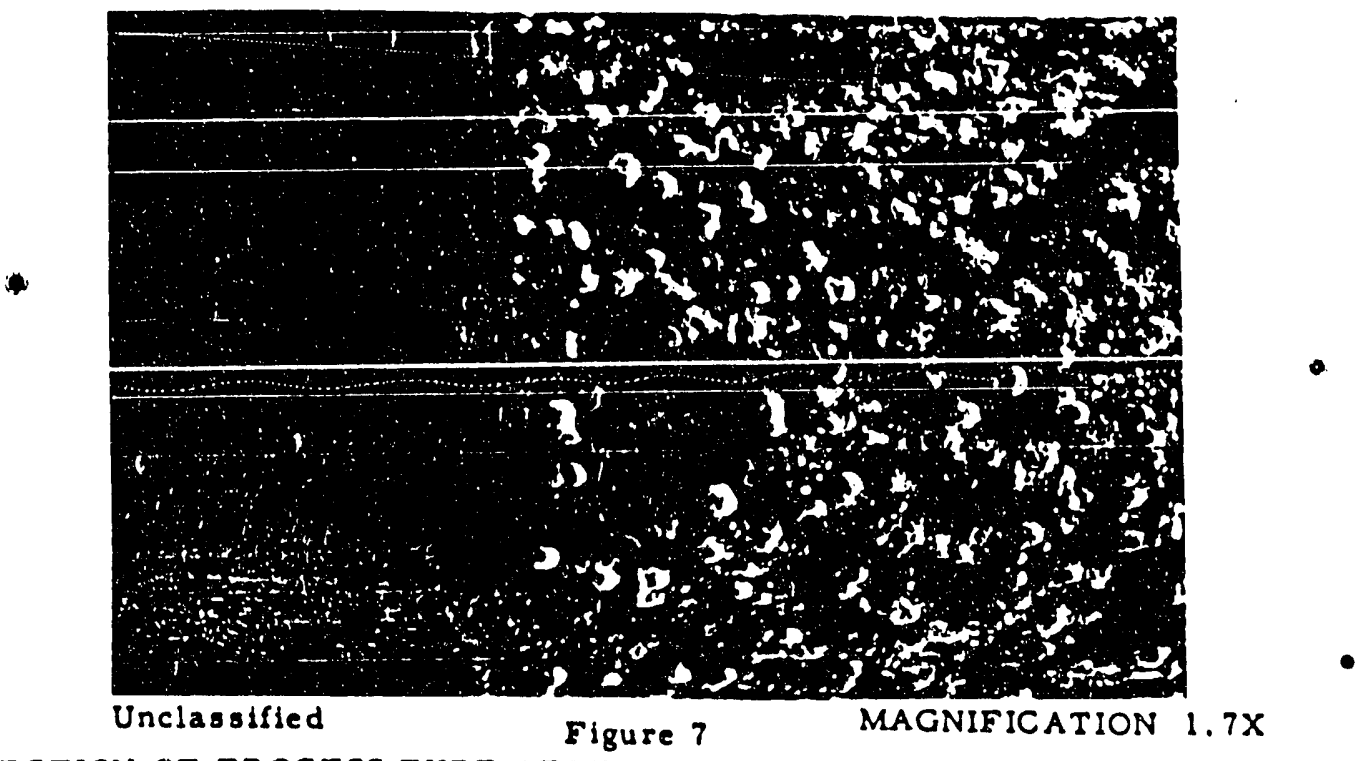

SECTION OF PROCESS TUBE AFTER EXPOSURE IN A GRAPHITE CHANNEL BLOCK FOR 168 HOURS AT $80 C$ (NOT DE-SCALED).

The unatlacked eection at the lelt was expoecd to alr, the corroded portion was in the Graphite Block.

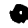

\section{DECLASSIFIED}




\section{DECLASSIFIED}

anodic film conditions were tested. An uncoated control sample was included for comparison.

The test samples were suspended vertically in individual four-inch graphite channel block sections and electrically connected to the graphite block through $10 \mathrm{ohm}$ resistors. Voltage drop measurements across the resistors in the external electrical circuit were utilized in calculating current flow. Pile-filtered water was introduced into the annulus between the tube and the block by means of a glass orifice. Excess water was allowed to run through the graphite block or run off the top of the blocks.

The coatings tested were variations of the Standard Alumilite film, applied to the exterior only of the process tube sections in thichnesses of $1 / 4,1 / 2$, and $1 \mathrm{mil}$. One sample for each coating thickness received one of two sealing treatments, being sealed in either (a) boiling water or (b) boiling 5 per cent sodium dichromate. One sample was tested unsealed. Coating technique and sealing methods are contained in Part II of the Appendix. The duration of the test was 688 hours.

Results:

Current measurements are plotted in Figure 8-A (Standard Alumilite - unsealeci), Figure 8-B (Standard Alumilite - sealed in boiling water), Figure 8-C (Standard Alumilite - sealed in boiling 5 per cent sodilum dichromatej alld Figure 9 (ivun-cuated process tuding).

Table II contains a summary of information obtained from the samples following completion of the test; including: (a) maximum force required to loosen the tube sections from the channel blocks; (b) pit depth measurements obtained by microscopic examinations and by means of a pit-depth micrometer; and (c) the approximate number of pits. A photograph of the uncoated test sample after removal of corrosion product is contained in Figure 10. The deep pitting attack occurred at the water inlet.

\section{DECLASSIFIED}




\section{DECLASSIFIED}

$H W-26395$

GALVANIC CURRENT FLOW FROM ALUMILITE ANODIZED PROCESS TUBE SECTIONS COUPLED TO GRAPHITE CHANNEL BLOCKS-ROOM TEMPERATURE
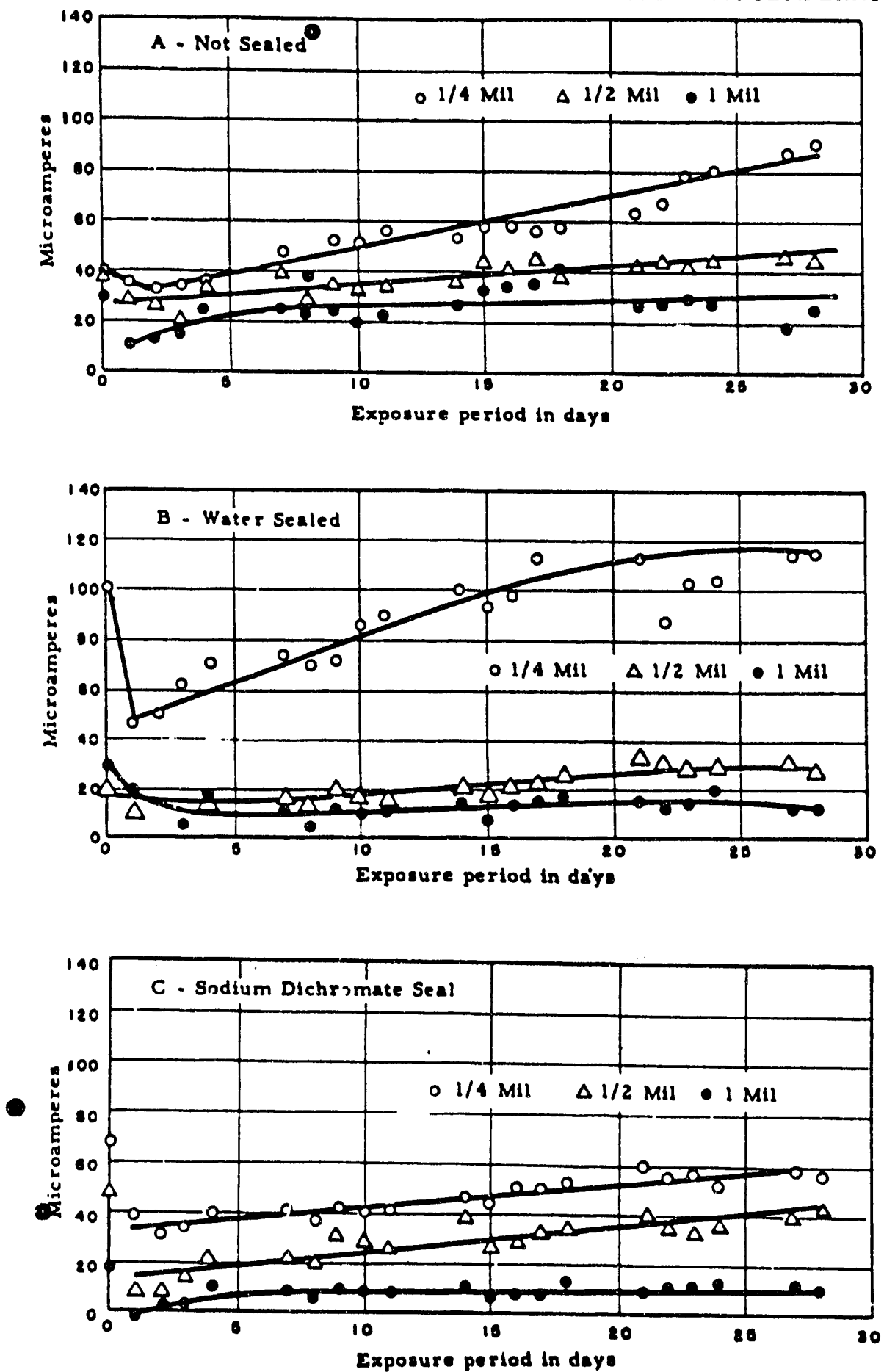

EIgure No. 6

\section{DECLASSIFIED}




\section{${ }_{-32 .}$ DECLSSIFED}

HW -26395

FIGURE 9

GALVANIC CURRENT FLOW FROM A NON-PROTECTED PROCESS TUBE SECTION COUPLED TO A GRAPHITE BLOCK - ROOM TEMPERATURE.
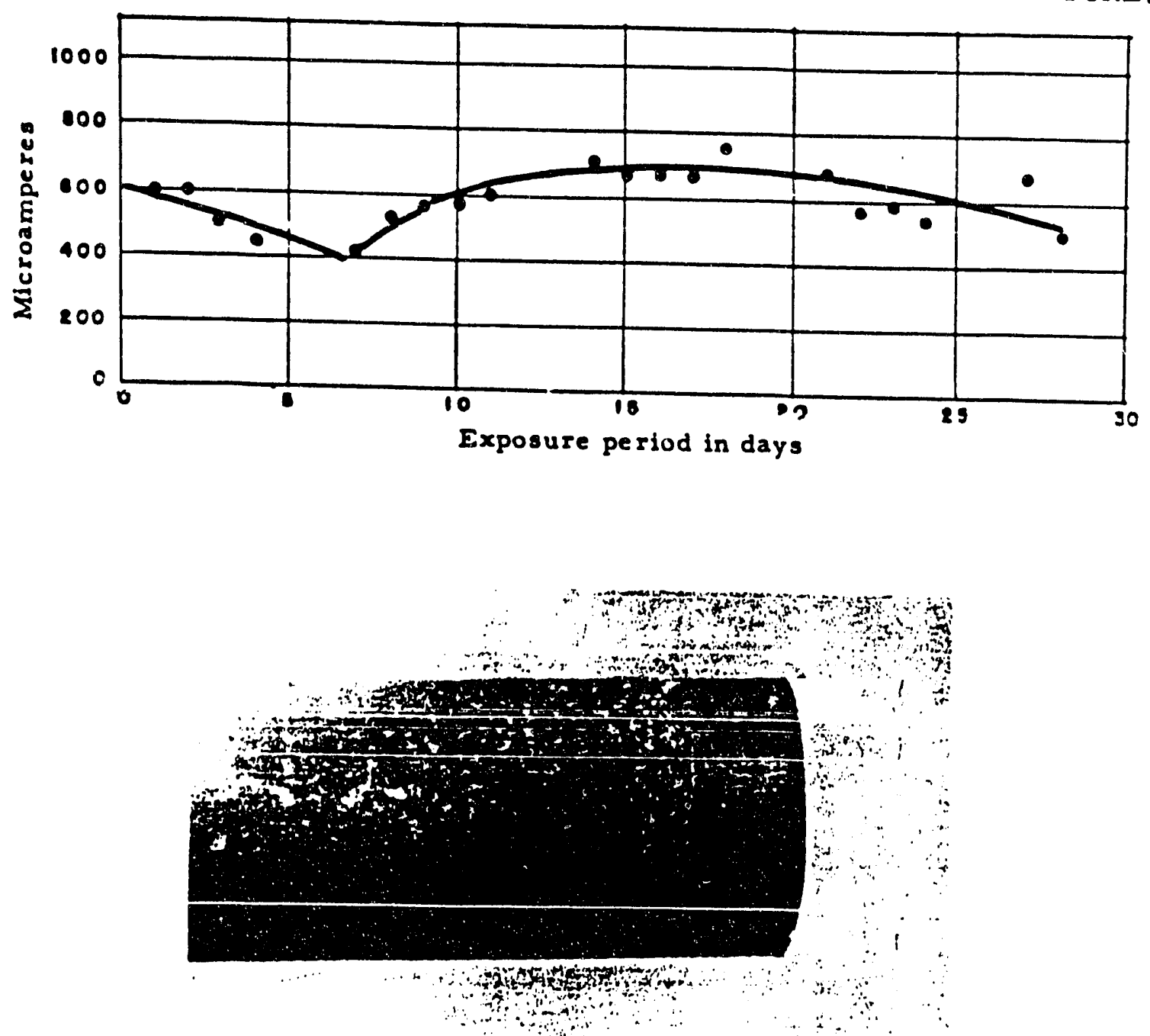

MAGNIFICATION IX

FIGURE 10

0

PITTING ATTACK ON NON-PROTECTED TUBE SECTION AFTER 28 DAYS EXPOSURE TO MOIST GRAPHITE AT ROOM TEMPERATURE.

Note deep pitting at water inlet on right site of sample. 
DECLASSIFIED

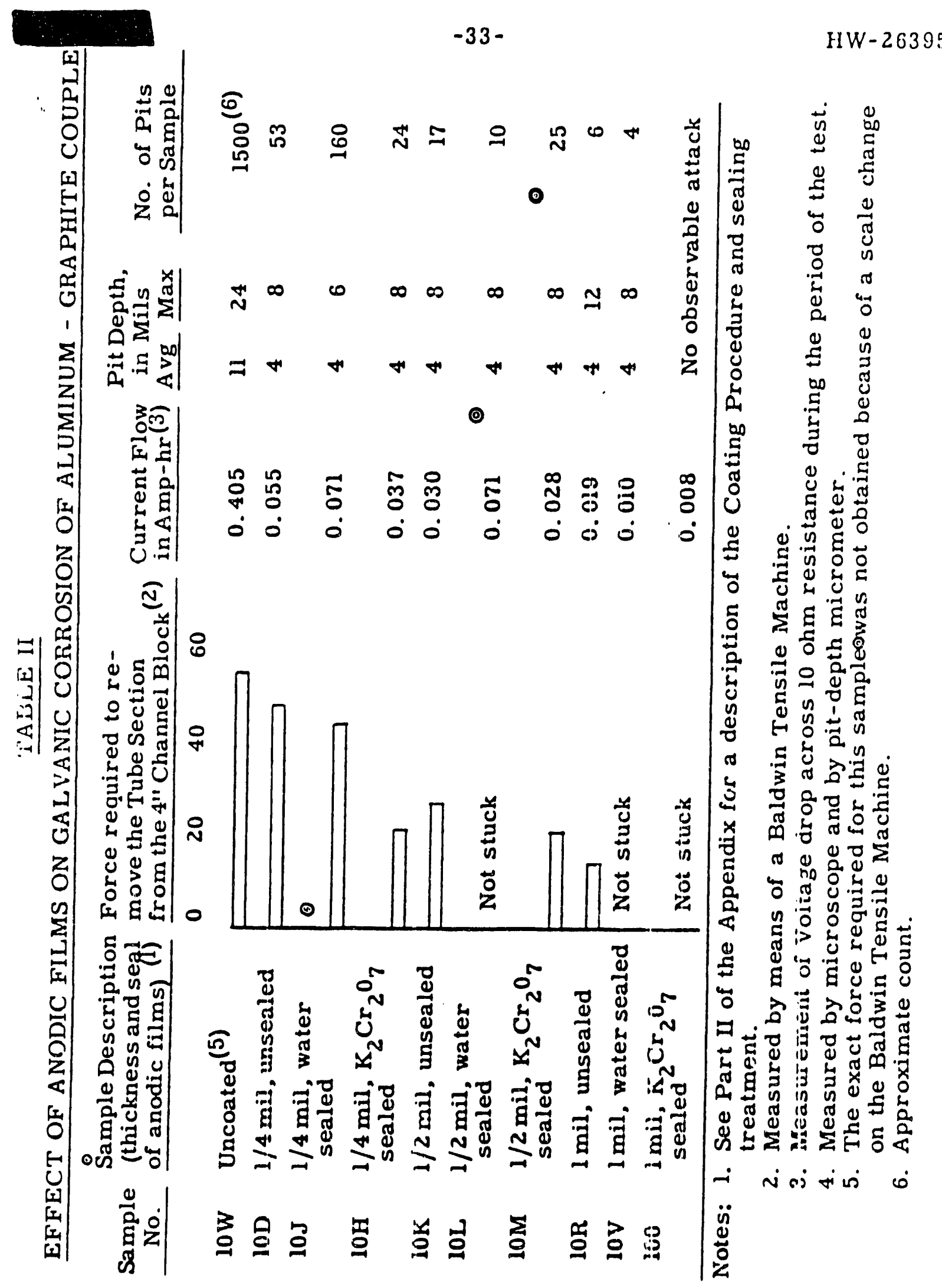

DECLASSIFES 


\section{DECLASSIFIED}

$-34-$

HW-26395

Test 7: Development of Elevated Temperature Test Unit
Description:

A six-inch length of process tubing was suspended vertically in a four-inch section of graphite channel block equipped with four cartridgetype, 150 watt, electrical heaters, connected in parallel. Temperature control was obtained by varying the voltage to the heater elements by use of a variable transformer. Several holes were drilled to accommodate thermometers so that the temperature of the block in the vicinity of the tube section could be checked.

(c)

The process tube section was connected electrically to the graphite block by means of an external wiring circuit, which included a 10 ohm resistor for current monitoring purposes.

The tube section was cleaned prior to the test in an inhibited alkaline cleaner but received no other surface preparation. After the setup was complete, pile-filtered water was introduced into the annulus between the tube and the block.

Results:

Temperature measurements indicated that the heating of the block was very uniform. Temperature control was adequate, but was sensitive to water flow rate, room temperature, and variations in line voltage.

After temperature control had been established, the effects of alternate wet and dry operation were studied. Figure 12 depicts the effect of this variation on current now between the tubes and the channel block.

After 76 days exposure (18.24 hours) it was noted that the inner diameter of the tube had been reducid near the water inlet end, the - decrease in diameter being $7 \mathrm{mils}$. At the end of the lest, after 148 days (3550 hours), the inner diameter had not degreased further. After completion of the test the sample was visually examined. The surface of the $\odot$

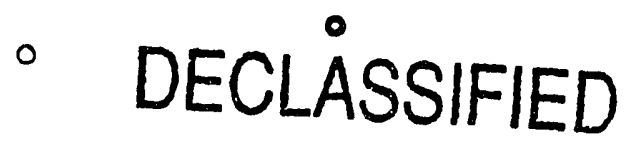




\section{DECLASSIFIED}

.33 .

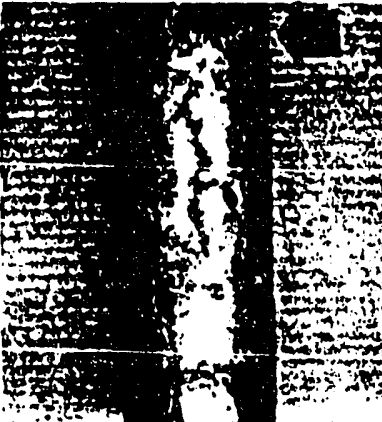

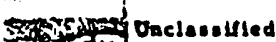

$\odot$
HW.2639s

MAONITICATION 3/10X

NON-PROTECTED PROCESS TUEE SECTION ATTER EXPOSURE IN A GRAPHITE CHANNEL BLOCK UNDER ALTEANATE WET AND DRY CONDITLONS TOR 140 DAYS AT YOC

The arrop pointe to the reglos of martmum aptack, the waler inlet.

Firure No. I

$\odot$

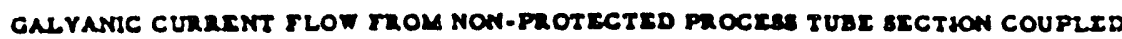
TO A GRAPHTTE BLOCK UNDER ALTERNATE WET AND DRY CONDITIONS AT $90 \mathrm{C}$

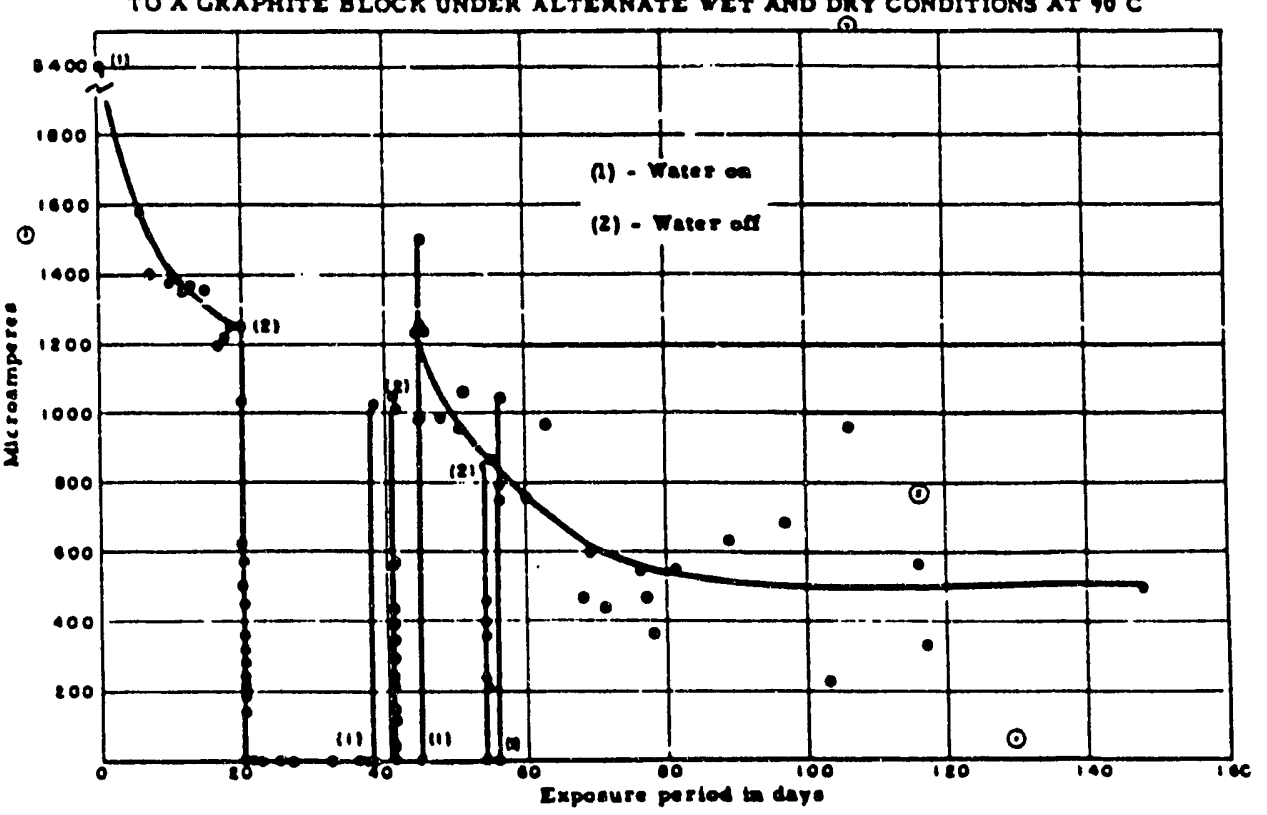

pigure ro. 18 


\section{DECLASSIFIED \\ -36 -}

HW -26395

sample from within the channel block was covered by a rust-colored film of corrosion product which was particularly thick near the water inlet. The corrosion product had cemented the tube into the graphite block, 1145 pounds of force being required to break the tube loose.

After cleaning in phosphoric acid - chromic acid solution (see Part II of the Appendix), the sample was observed to be most deeply attacked at the water inlet portion, the maximum pit depth being 35 mils. The altack in the region of greatest penetration had probably been pltting in the early stages of corrosion; however, corrosion had been so severe that the pits had grown together, and the appearance was one of uniform though localized penetration. The remainder of the sample was covered by numerous small pits approximately 4 or 5 mils deep. The weight loss was 1.2412 grams; calculations from current flow indicate a galvanic weight loss of 0.774 grams. Figure 11 is a photograph of the sample after cleaning.

\section{Test 8: Coating Evaluation at Ronm Temperature}

Description:

Based on the corrosion test unit design developed in Test 6 , an expanded room temperalure lest was established to confirm the information obtained from Test 6 and to furnish additional information. Figure 13 is a photograph of the room temperature test unit. A stainless steel header was connected to the plle-filtered water system and supplied water to the samples as Illustrated in Figuros 13 and 11 . Elcctrical connections required to connect the process tube section to the channel block and also required for current llow monitoring were made to the sample and the block, as shown by the dark and white wires in Figure 14. The leads were brought out to a switch box located in the center of the assembly shown in Figure 13. In series with the electrical leads were resistors (10 ohms for the non-protected samples, 50 ohms for the coated samples) to bo used in monitoring the curront flow.

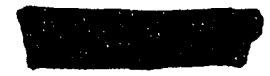




\section{DECLASSIFIED}

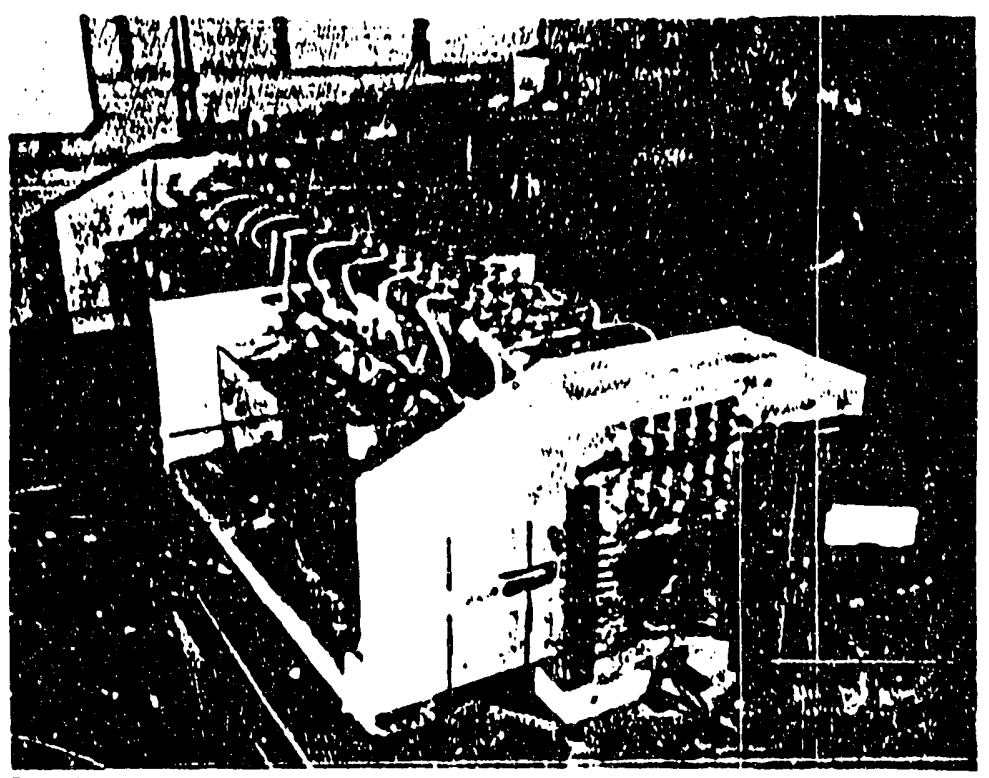

Unclassified

Figure 13

ROOM TEMPERATURE TEST UNIT

Running along the top of the unit may be set:n the stainless steel header supplying water to the graphite blocks. In the foreground is the switch box and the Millivac vacuum tube volt meter.

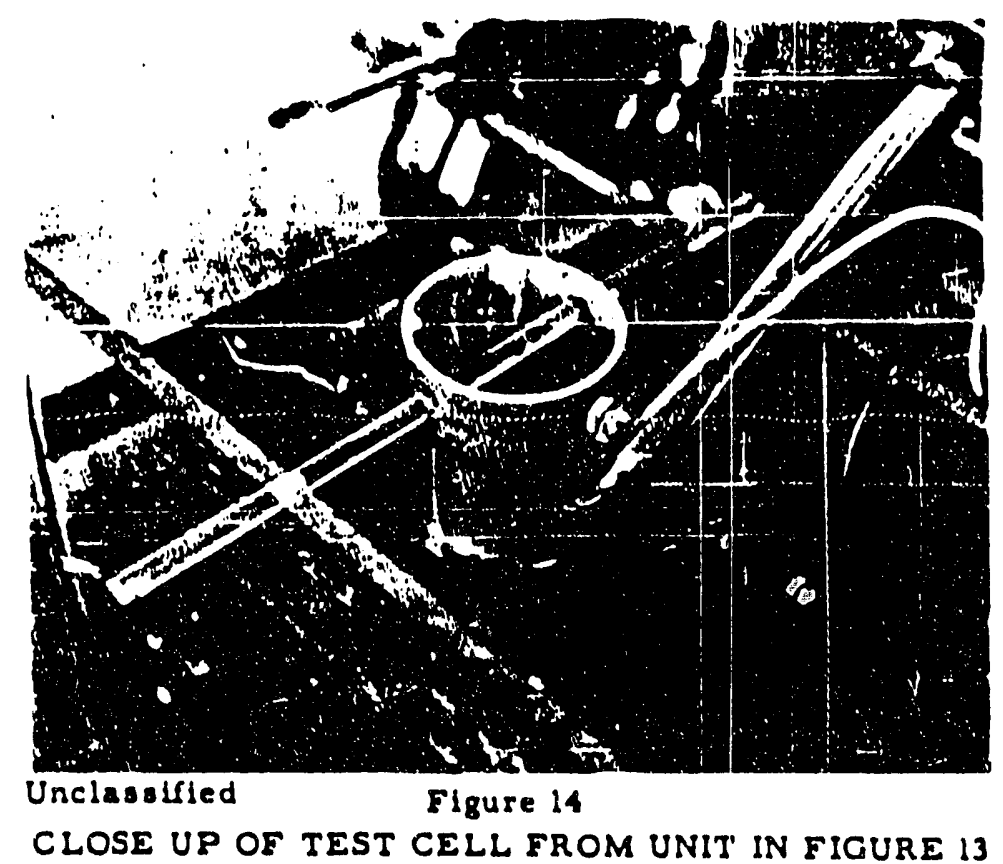
Note water inlet and elecirical connections. 


\section{DECLASSIFIED}

The coatings evaluated in this apparatus were:

(a) Standard Alumilite, 1/2 and 1 mil thick, unsealed.

(b) Standard Alumilite, $1 / 2$ and 1 mil thick, sealed in boiling water.

(c) Standard Alumilite, $1 / 2$ and 1 mil thick, sealed in boiljing 5 per cent potassium dichromate solution.

(d) Aqua Dag, brushed on, coating thickness unknown.

Two samples of each coating were tested, one of which was scratched through the coating to expose the bare aluminum tube. Methods of coating application are discussed in Part II of the Appendix. Included for comparison purposes were uncoated samples of process tubing. Six non-protected samples were included in order that they could be removed from the test after increasing exposure periods.

The exposure periods for the various samples in the test were:

(a) Anodized samples - 134 days (3216 hours)

(b) Aqua-Dag coated - 139 days (3336 hours) $\circ$

(c) Uncoated samples - 12 days (288 hours)

23 days (552 hours) 48 days (1152 hours) 63 days (1512 hours) 90 days (2160 hours) 138 days (3312 hours)

After the test, the samples were removed from the graphite blocks by use of a Baldwin Tensile Machine to apply and measure the force. After visual examination, the corroded samples were cleaned in the following manner:

(a) All anodized samples were cleaned in concentrated (70 per cent) nitric acidat room temperature. This served to dissolve all water-deposited saits and to loosen the corrosion

- 
product for removal. The solution had no observable effect on the anodic films.

(b) The Aqua-Dag coated samples were cleaned by scrubbing in water to remove the colloidal graphite deposit and then immersing in the standard phosphoric acid-chromic acid solution (see Part II of the Appendix).

(c) The non-coated sa.nries were descaled in the standard phosphoric acid-chromic acid solution (see Part II of the Appendix).

Results:

Table III and Figures 15, 16, 17, and 18 contain the pit depth measurements, current flow measurements, for ce required to loosen the tubes in the graphite blociss, weight change data, and visual observation for the non-protected tube sections and Aqua-Dag coated samples. Table IV and Figures 19 and 20 contain the results for $1 / 2$ and $1 \mathrm{mil}$ Alumilite anodized samples, current flow, weight change data, breaking force, pit depth measurements, and visual observations.

Photographs of samples are included in Figures 21, (non-protected samples), 22 (Aqua-Dag coated samples), 23 (anodized samples $1 / 2 \mathrm{mil}$ ), and 24 (anodized samples, $1 \mathrm{mil}$ ).

Test 9: Coating Evaluation at $90 \mathrm{C}$

(1)

\section{Description:}

Based on design information obtained from the first high temperature test cell and on the large scale room temperature test, a unit was fabricated to accommodate 24 galvanic corrosion study cells. The aluminum process tube sections were mounted horizontally within 4-inch sections of channel block and electrically connected to the blocks through a 10 ohm resistor. Heat was furnished to the blocks by means of 4 electrical heaters, connected in parallel and connected to a variable transformer.

\section{DECLASSIFIED}


DECLASSIFIED

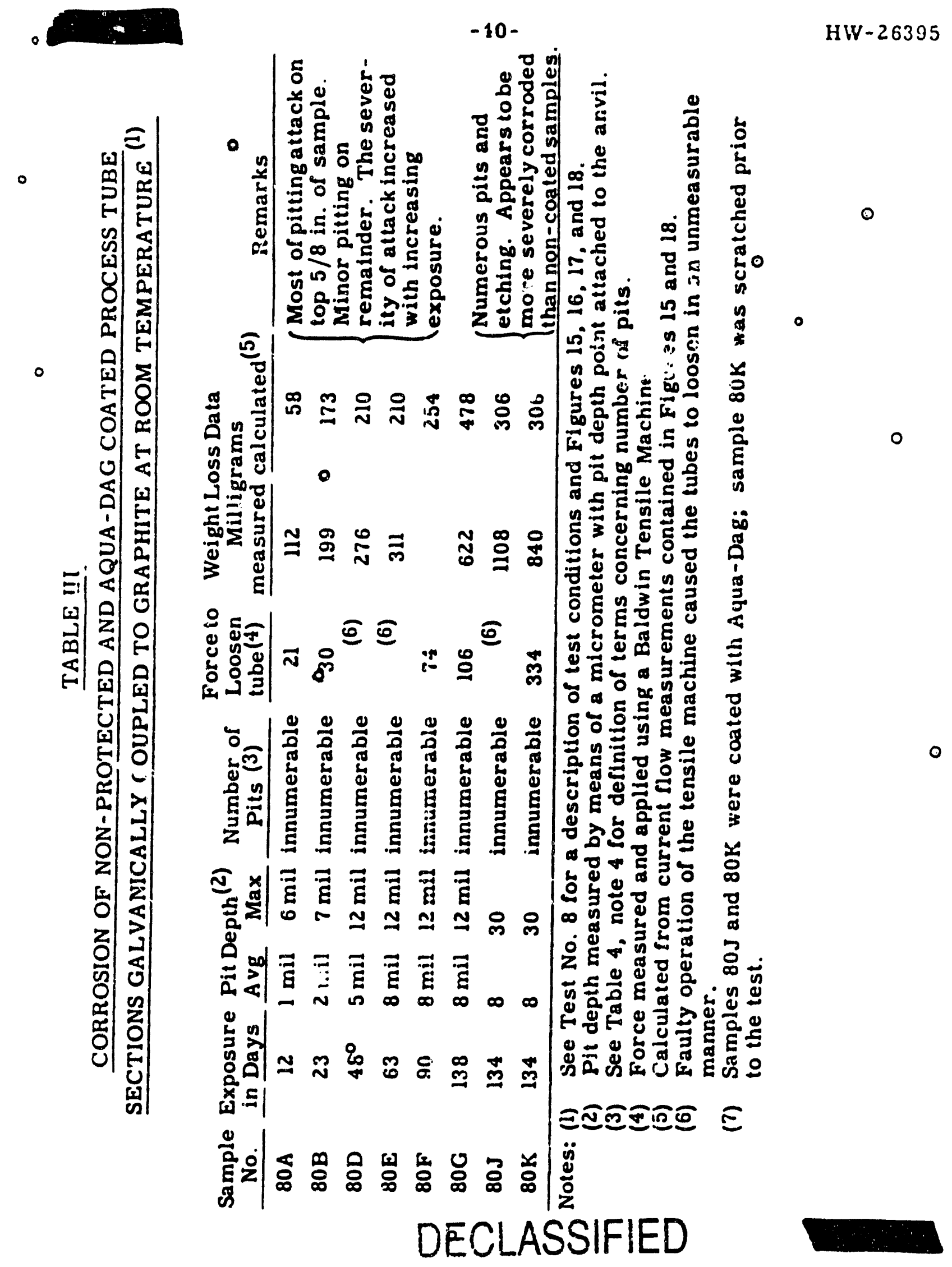




\section{DECLASSIFIED}

$-41-$

GALVANIC CURRENT FLOW FROM NON-PROTECTED PROCESS TUBE SECTIONS COUPLED TO GRAPHITE CHANNEL BLOCKS - ROOM TEMPERATURE

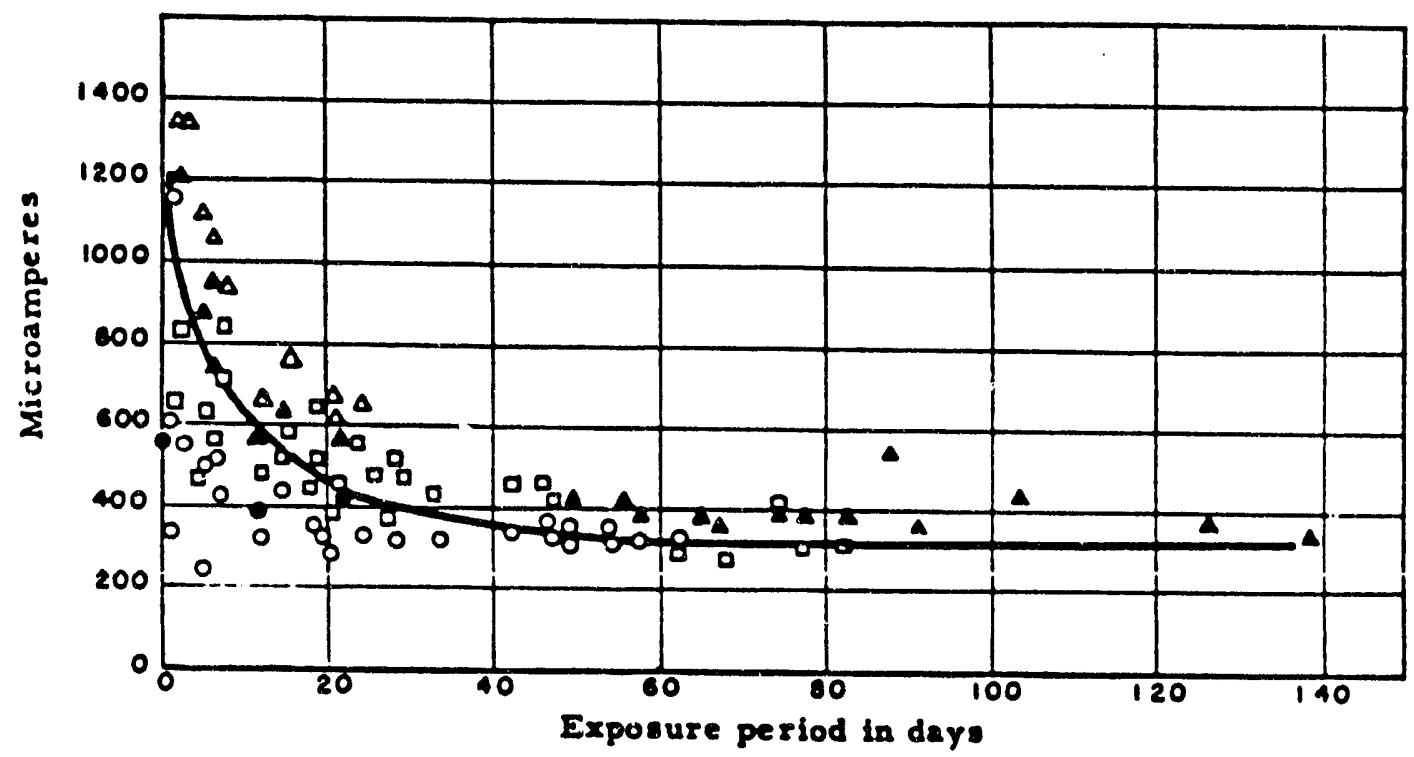

Figure No. 15

WEIGHT LOSS ON NON-PROTECTED PROCESS TUBE SECTIONS COUPLED TO GRAPHITE CHANNEL BLOCKS - ROOM TEMPERATURE -

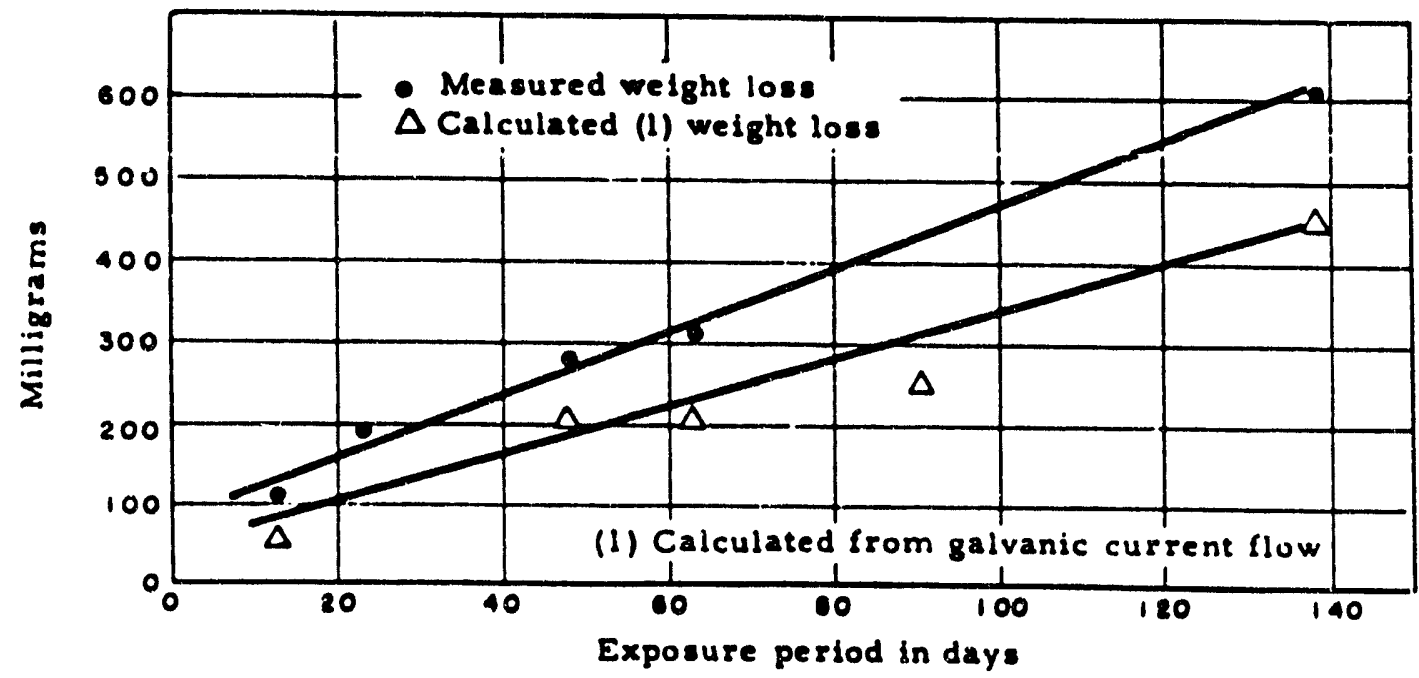

Figure No. 16 


\section{DECLASSIFIED}

$-42$.

$H W-26395$

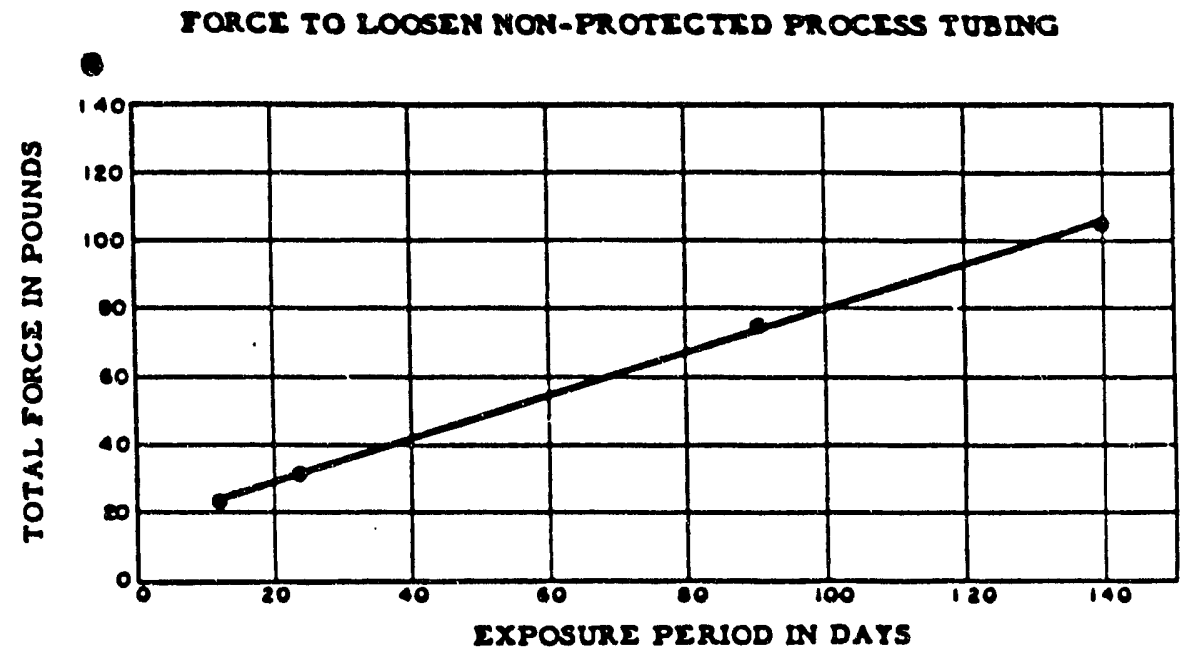

(2)

Flgure No. 17

GALVANIC CURRENT FLOW JROM SECTIONS OT PROCESS TUBING COATED WIIH AQUA-DAG, COUPLED TO GRAPHITE CHANEL BLOCKS - ROOM TEMPERATURE

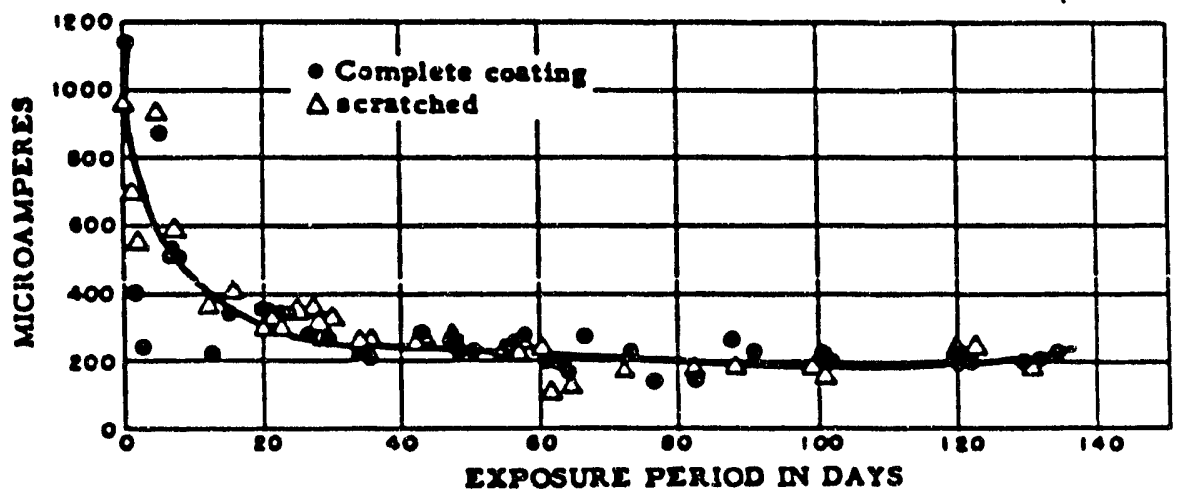

Figuse No. 18 


\section{DECLASSIFIED}

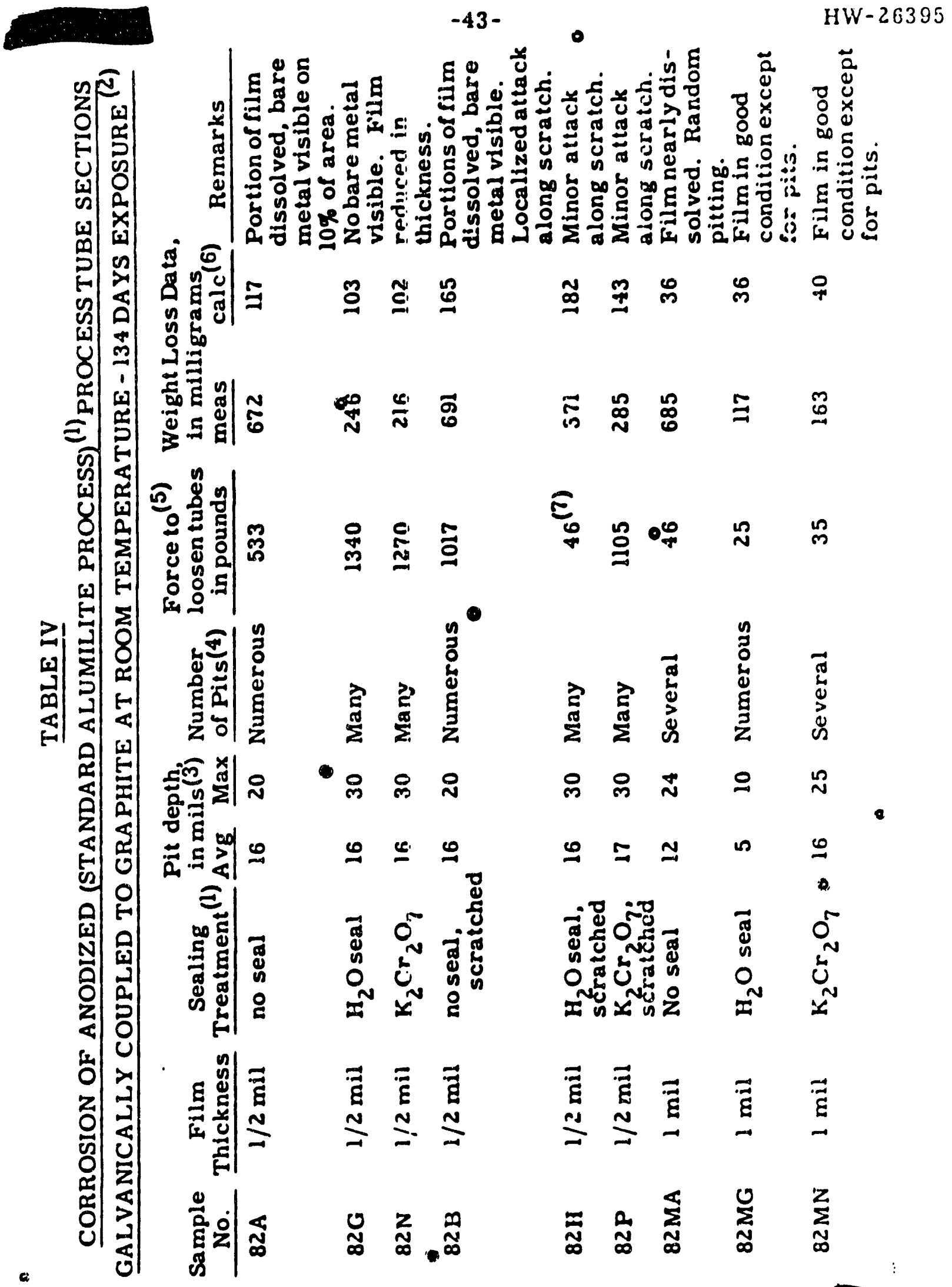

DECLASSIFIED 


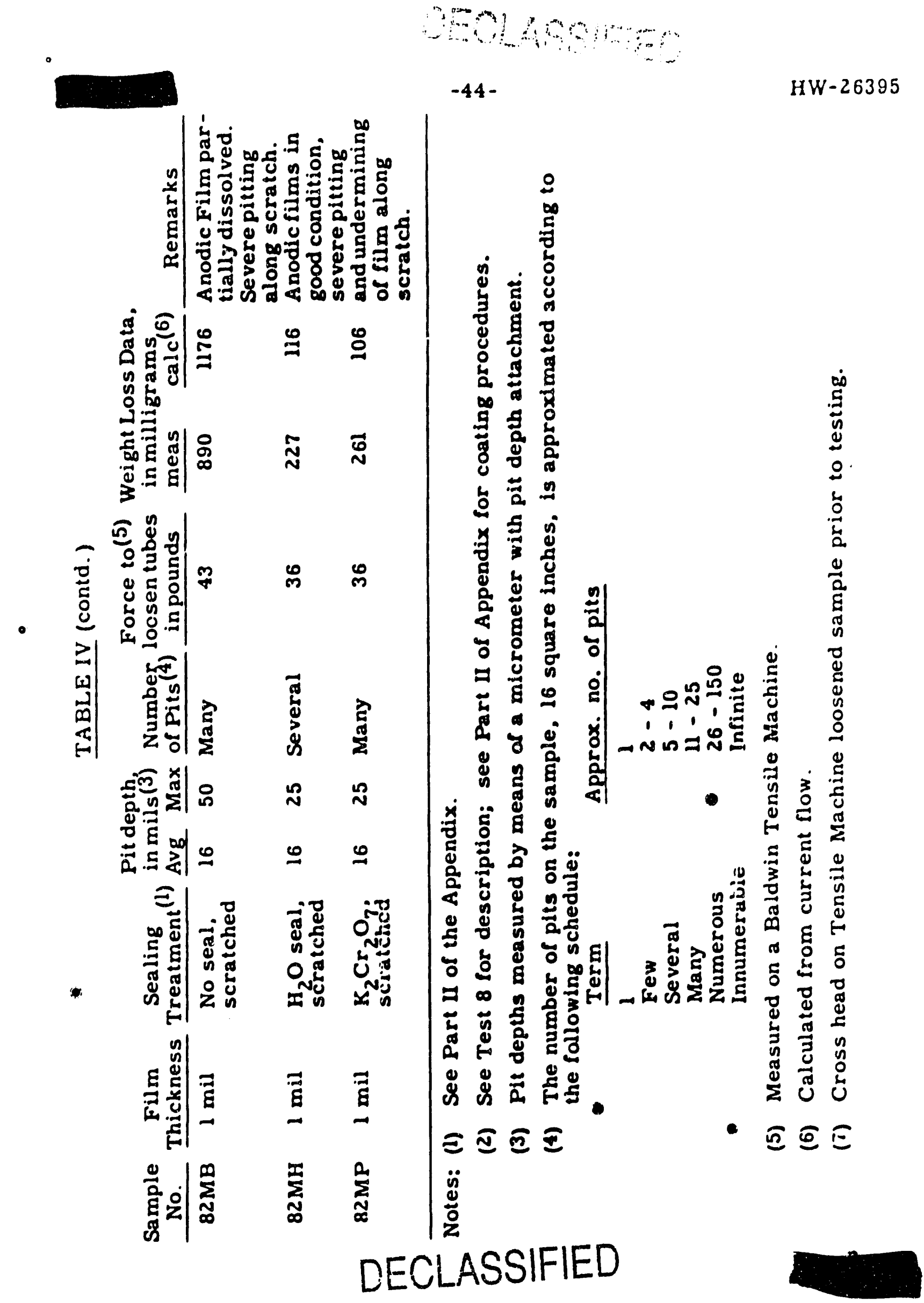


GALVANIC CURRENT FI.OW TKOM ALUMLITE ANODIZED PROCESS TUEE SECTIONS

(3) I/2 MIL FILM THICKNESS - COUPLED TO GRAPHITI DLOCKS - ROOM TIMPERATURE
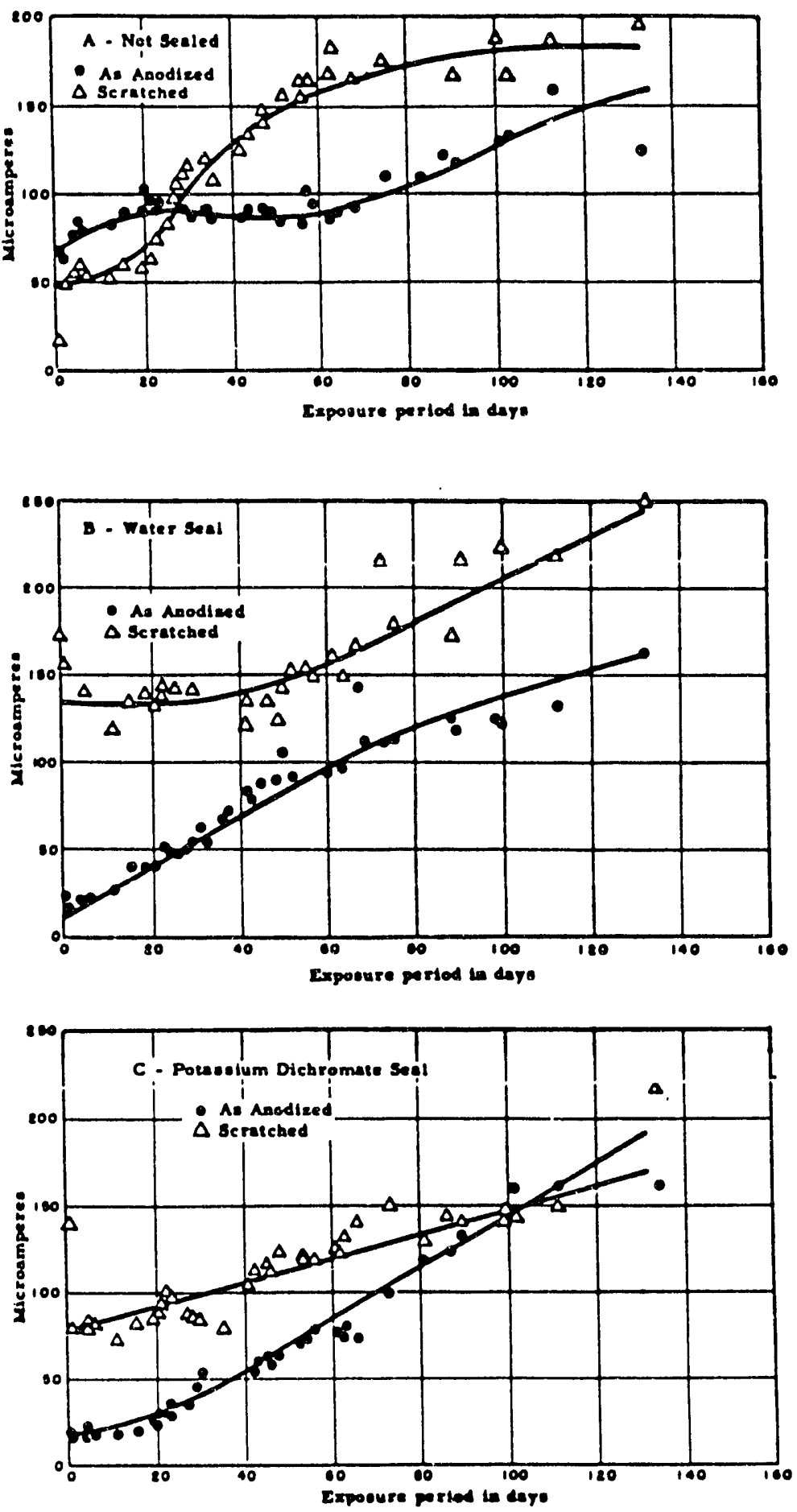

rigure No. 19 


\section{DECLASSIFIED}

-46.

OALVANIC CURRENT TLOF MOM ALUMALTTE ANODIZED - I MIL TILM - PROCESS

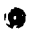
TUEI SICTIONS COUPLID TO ORAPHITE DLOCKS - ROOM TE MPERATURT
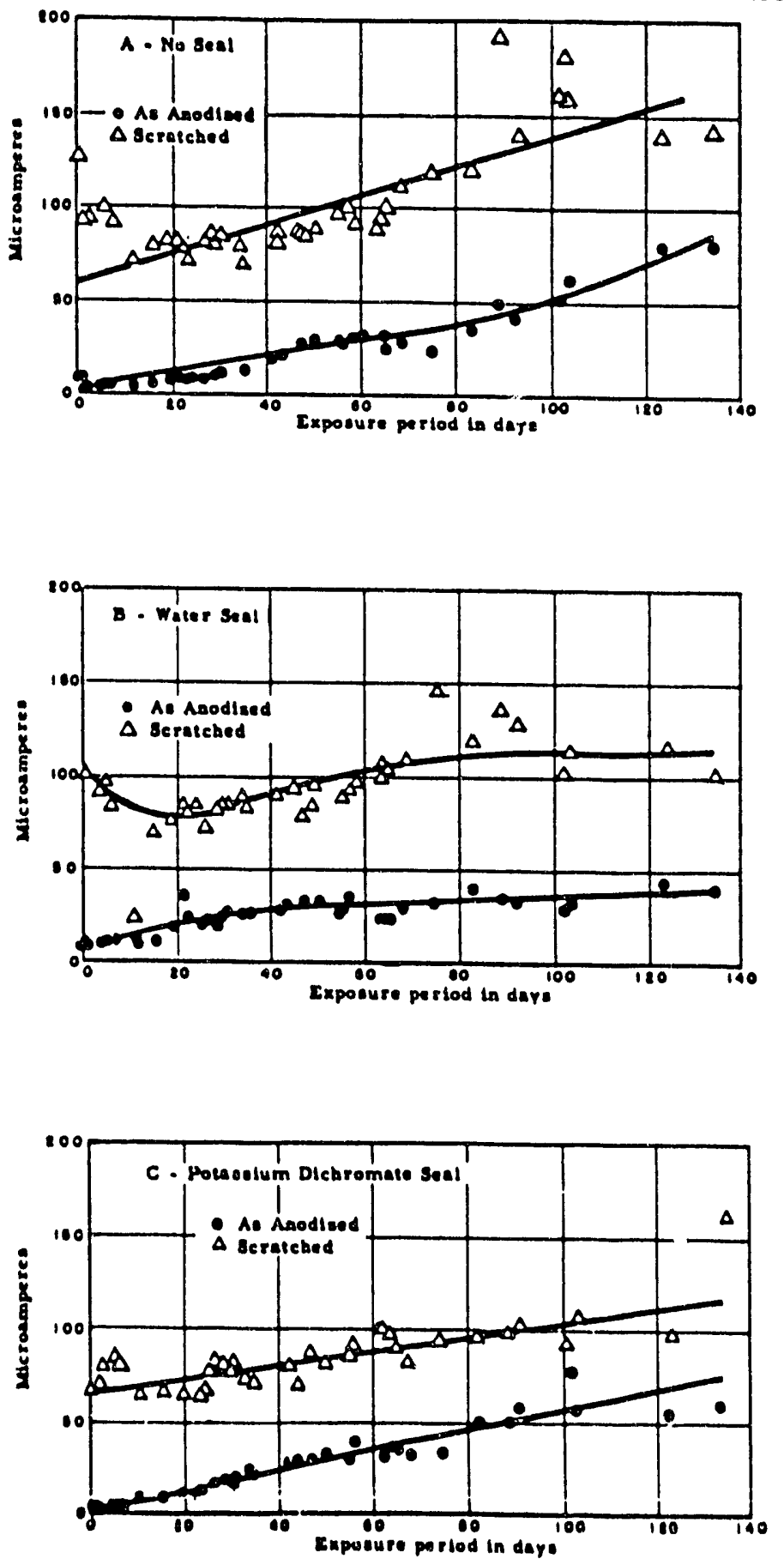

DECLASS|F|ED 


\section{DECLASSIFIED}

$-47$.

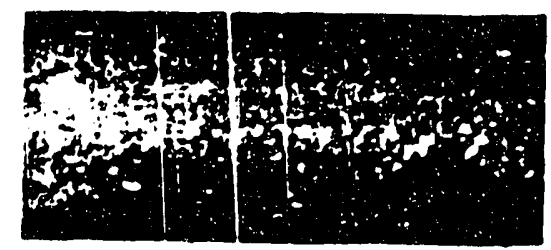

a

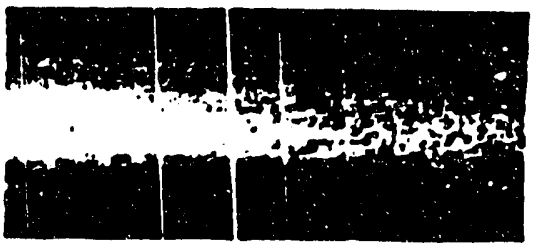

焦

帒

茴

it

if

( of

a

-

นึ้

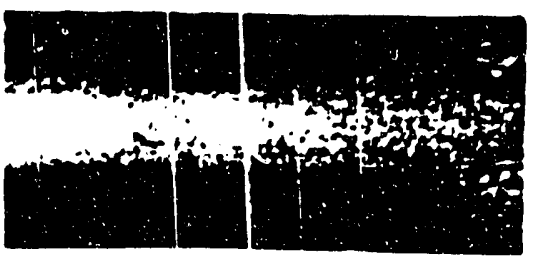

$\stackrel{x}{\underline{x}} \quad \mathrm{~J}_{\mathfrak{4}}^{4}$

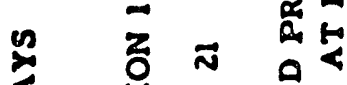

ช

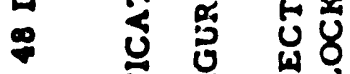

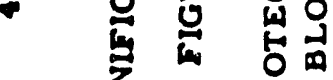

.

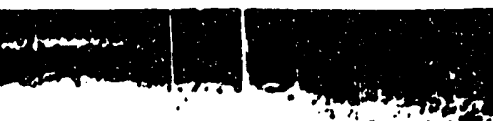

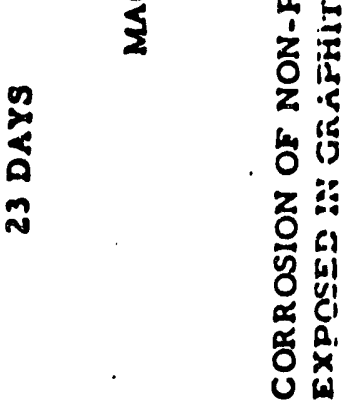

Unciesolfied

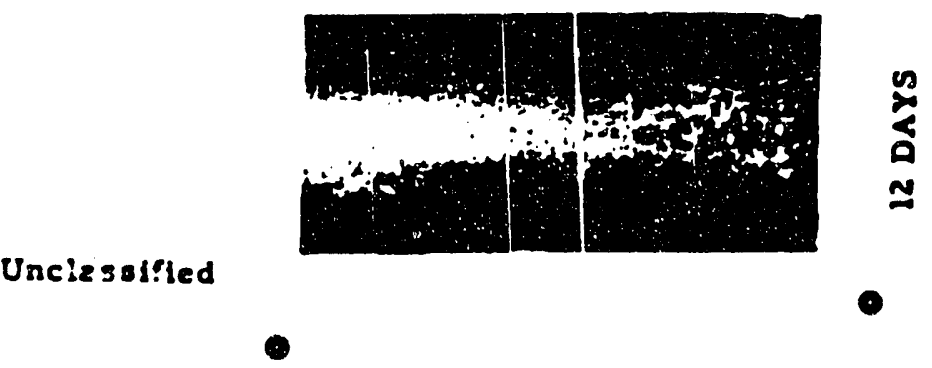

0
$\vdots$
2 


\section{DECLASSIFIED}

$-48-$

HW -26395

(1)

Unclassified
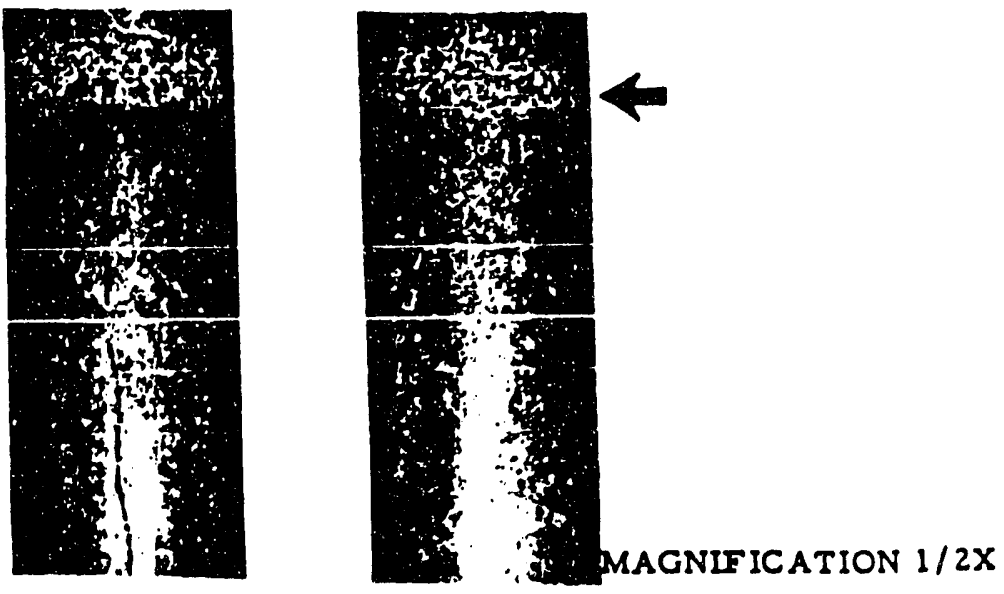

FIGURE 22

SECTIONS OF PROCESS TUBING COATED WITH AQUADAG AETER EXFOSURE UN GRAFHiTE CHANNEL DLOUKS FOR 134 DAYS AT ROOM TEMPERATURE.

The arrows point to the region of deepest penetration, the water inlet.

-

○ 


\section{DECLASSIFIED}
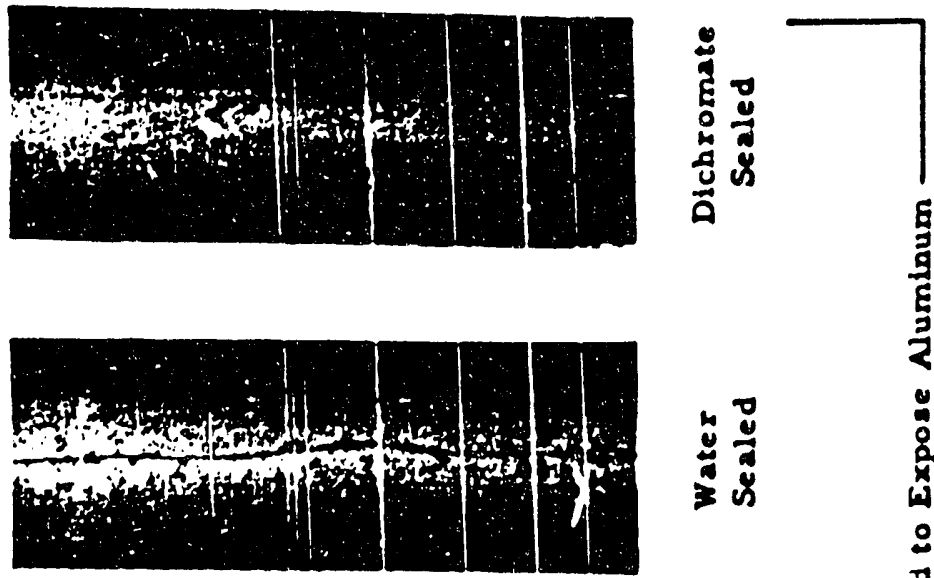

旅
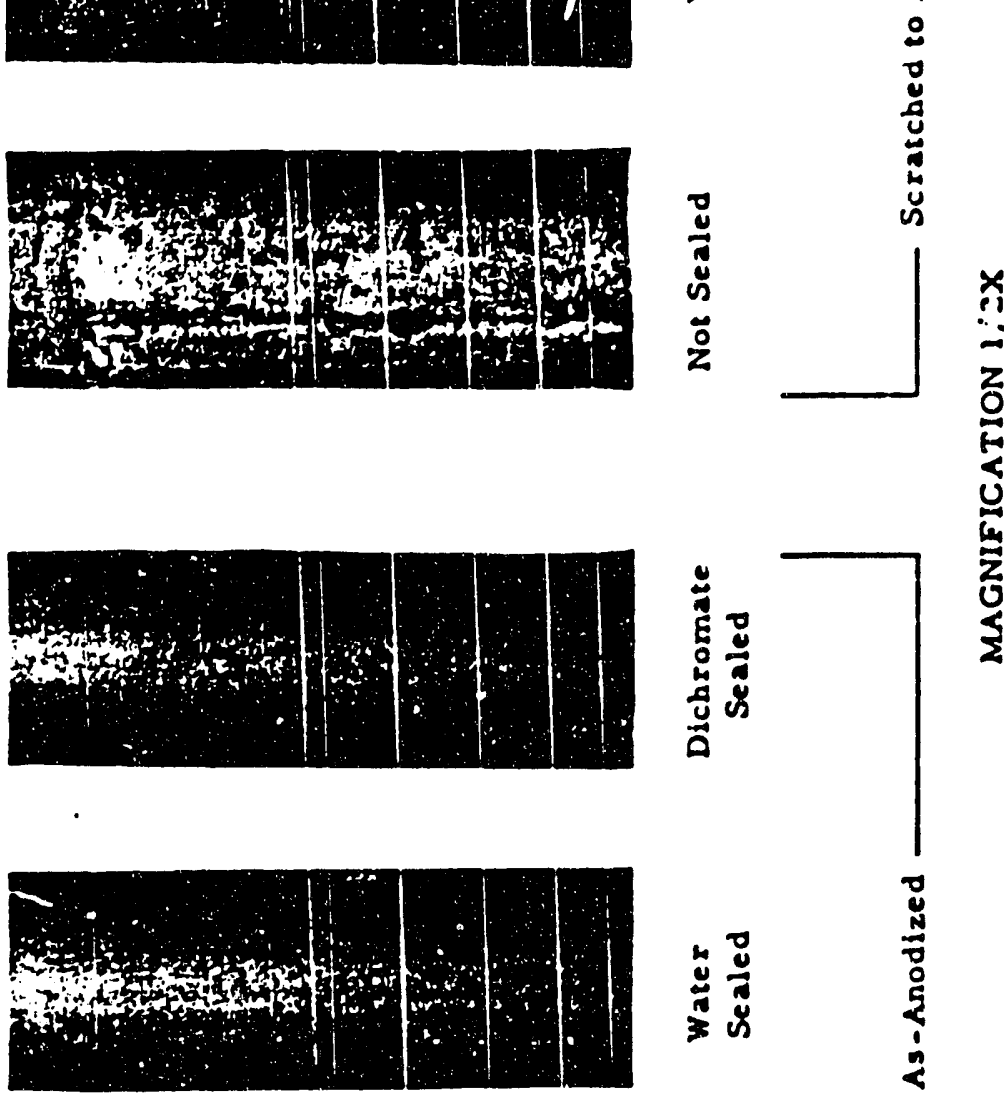

$x$
4
$y$
3
3

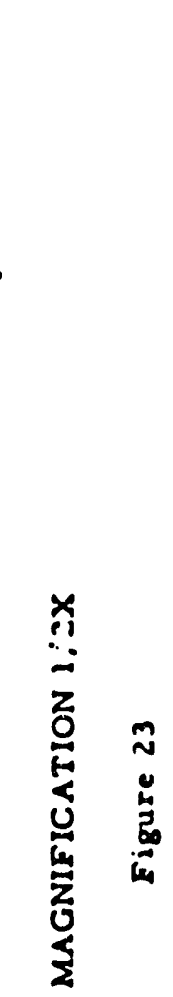

告
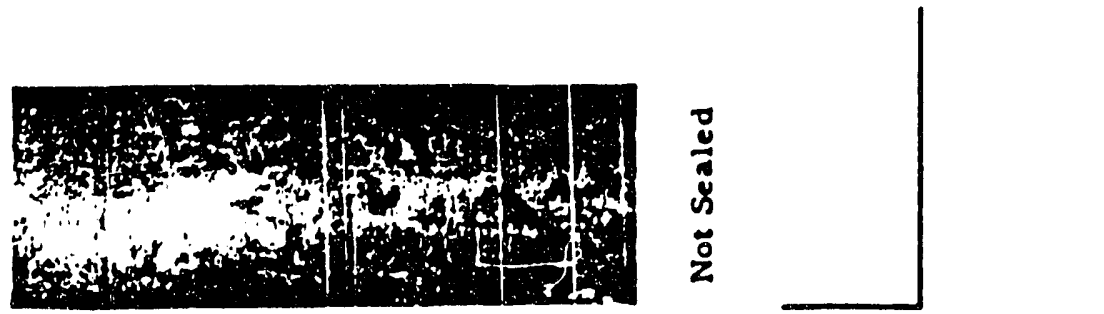

Unclasolfled

DECLASSIFIED 


\section{DECLASSIFIED \\ $-50-$}

HW -26395
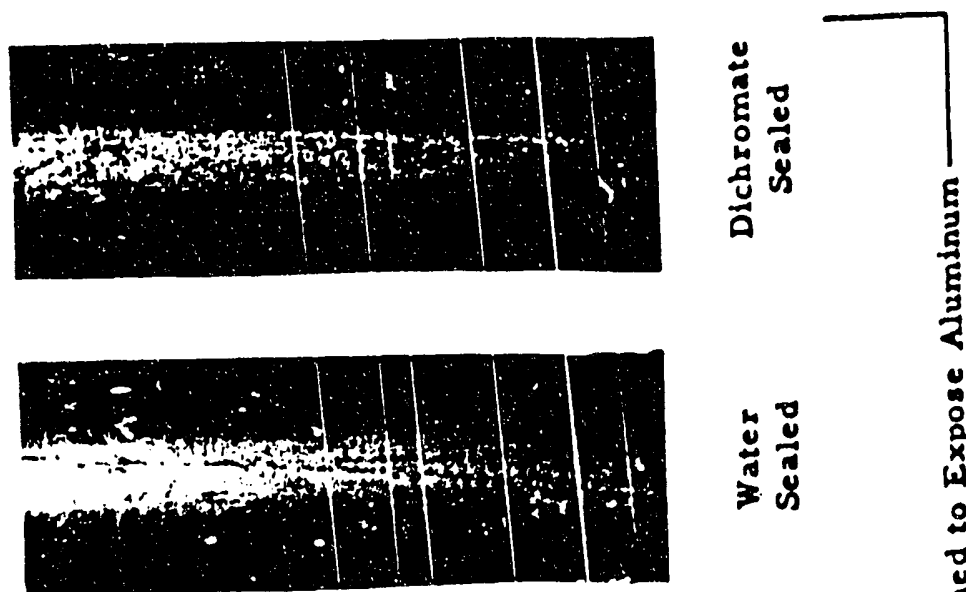

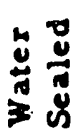

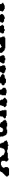
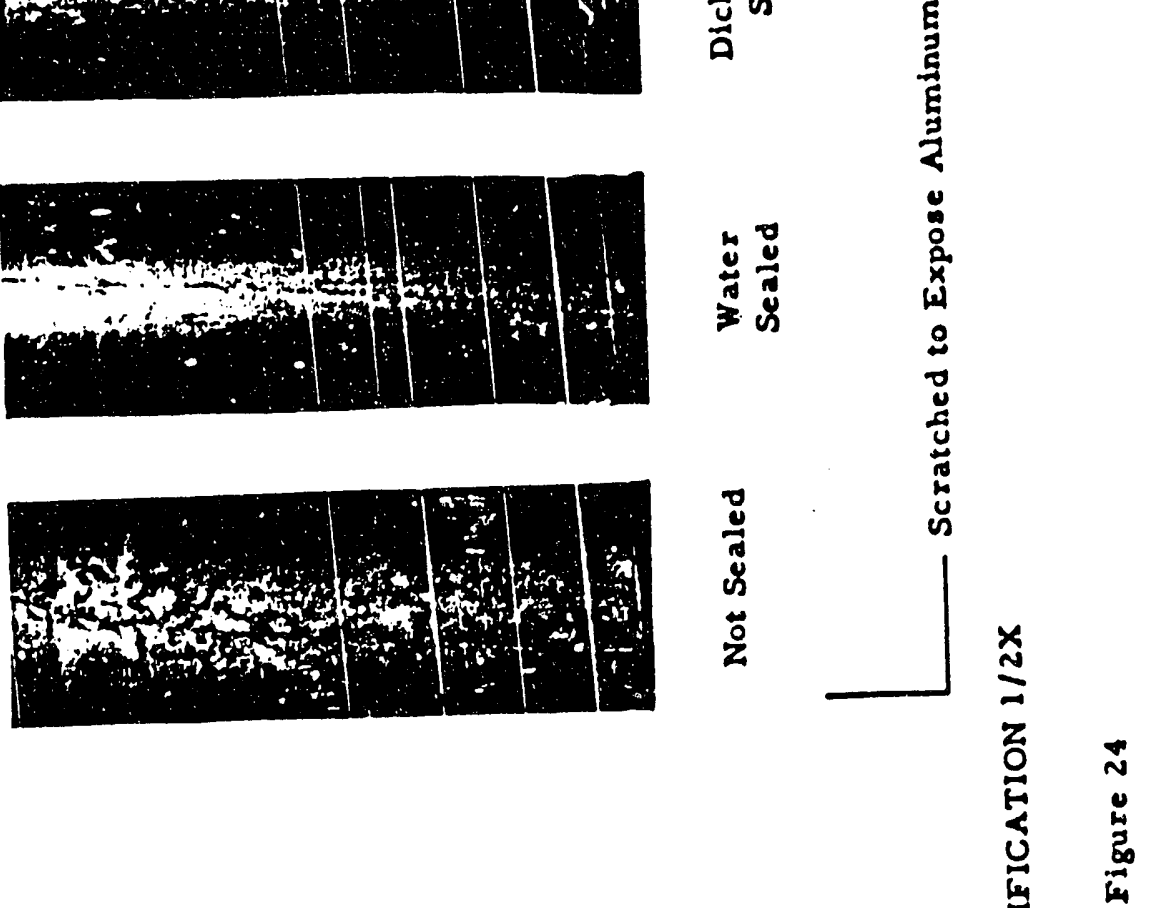

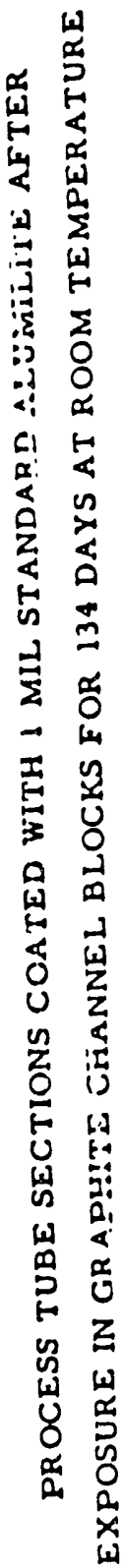

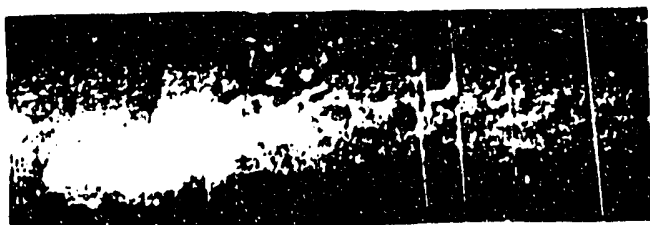

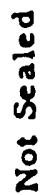

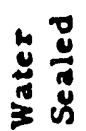

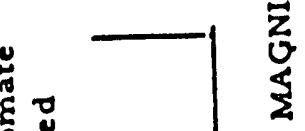

Unclasslfied

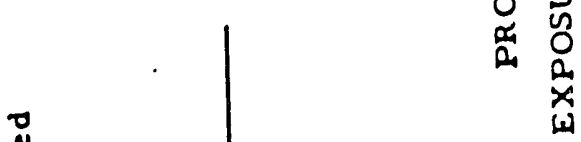

DECLASSIFIED 


\section{DECLASSIFIED}

$-51-$

HW-26395

Figures 25 and 26 illustrate the high temperature unit and control system. Temperature control was manual in that the variable transformers were adjusted by an operator to obtain the desired temperature. Variations in room temperature, water flow rate and line voltage were compensated for by adjusting the transformers.

Water for the galvanic couple was introduced into the annulus through a series of holes contained in a well at the top of each block. The method of water introduction is illustrated in Figure 26. The coatings evaluated at $90 \mathrm{C}$ were:

(a) Standard Alumilite, 1/2 and $1 \mathrm{mil}$, unsealed

(b) Standard Alumilite, 1/2 and $1 \mathrm{mil}$, water sealed

(c) Standard Alumilite, 1/2 and $1 \mathrm{mil}$, dichromate sealed, dichromate solution

(d) Standard Alumilite, 1/2 mil, sodium silicate sealed

(e) Chromic acid Anodized, decorative film, 1/4 mil, unsealed

(f) Chromic acid Anodized, protective $f i l m, 1 / 4 \mathrm{mil}$, unsealed

(g) Alumilite Hard Coating, $1 \mathrm{mil}$, unsealed

(h) Martin Hard Coating, 2 mils, unsealed

Samples of items $a, b, c, d$, and $h$, containing a longitudinal scratch through the anodic film, were tested under the same conditions as the as-anodized samples and for equivalent exposure periods. The coating and sealing procedures are contained in Part II of the Appendix.

Uncoated samples of process tubing were included for comparison purposes. Six samples were tested in order that they could be removed from the test after increasing periods of exposure.

Exposure periods for the samples are contained in Tables $\mathrm{V}$ and VI. After the test, the corroded samples were removed from the graphite blocks using a Baldwin Tensile Machine to supply and measure the force. After visual inspection, samples were cleaned in the following manner:

- 


\section{DECLASSIFIED}

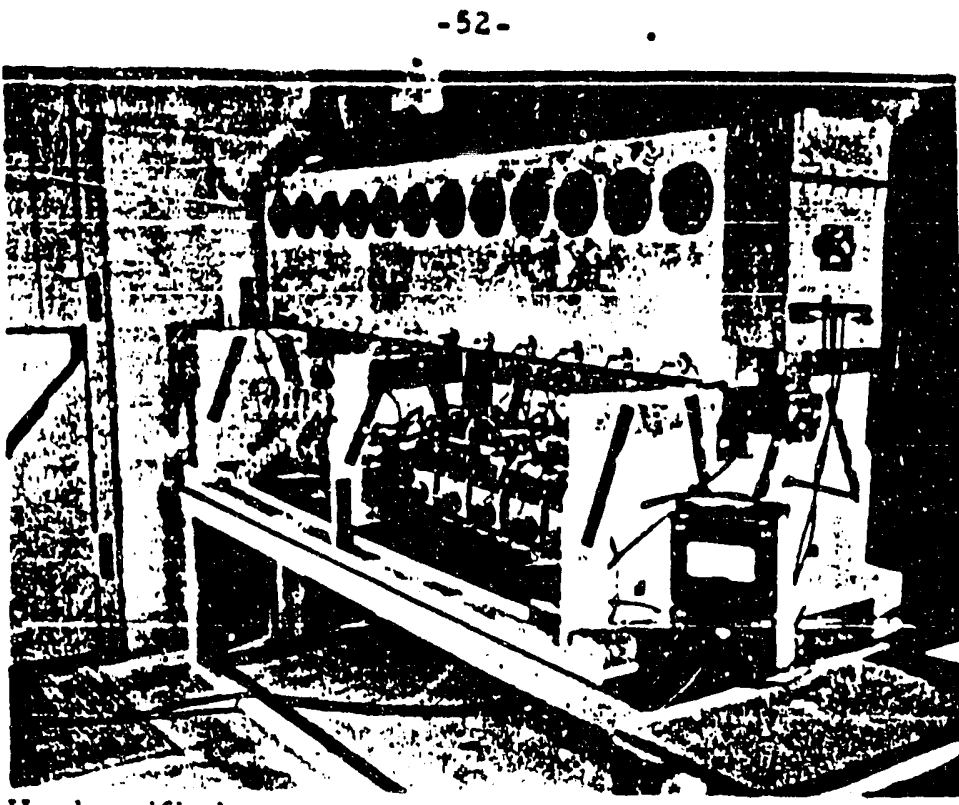

$H W-26395$

Unclassified

Figure 25

OVER - ALL VIEW OF THE HIGH TEMPERATURE GALVANIC

COUPLE TEST UNIT. THE CURRENT MEASURING EQUIPMENT IS SHOWN IN 'THE FOREGROUND.

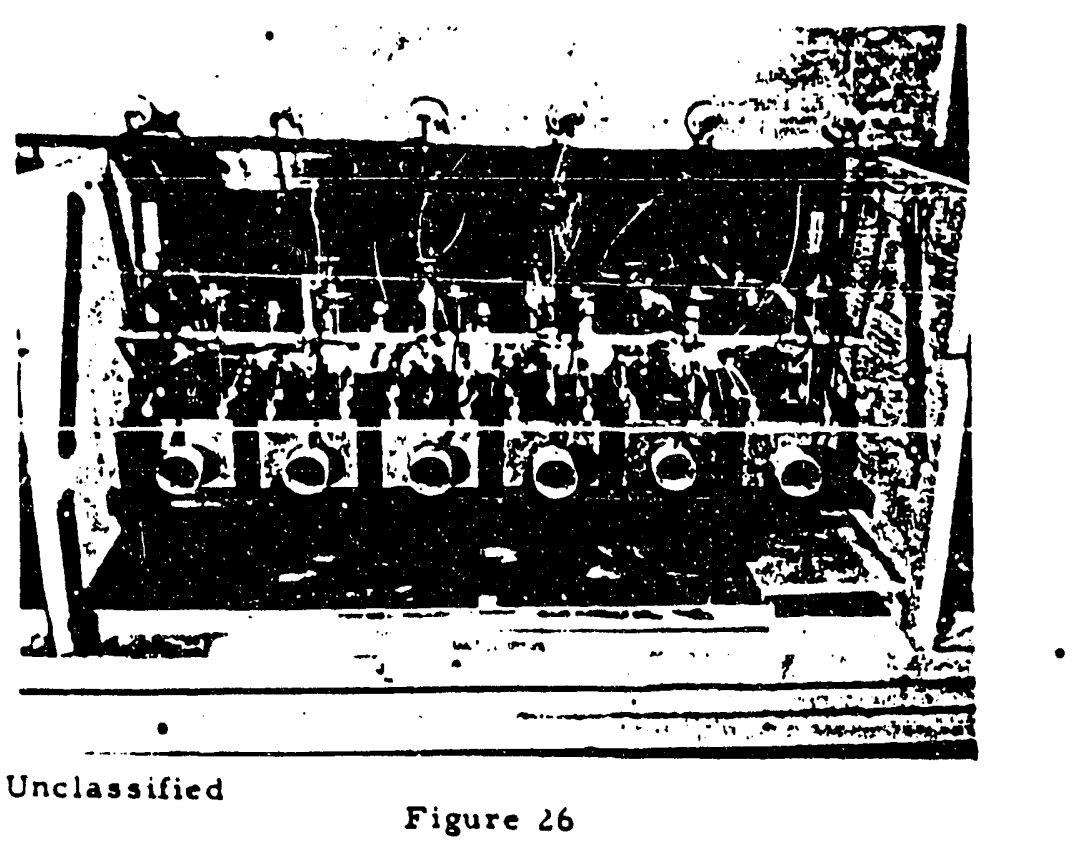

DETAIL OF THE HIGH TEMPERATURE GALVANIC COUPLE TEST UNIT SHOWING 6 OF THE 24 TEST CELLS. 


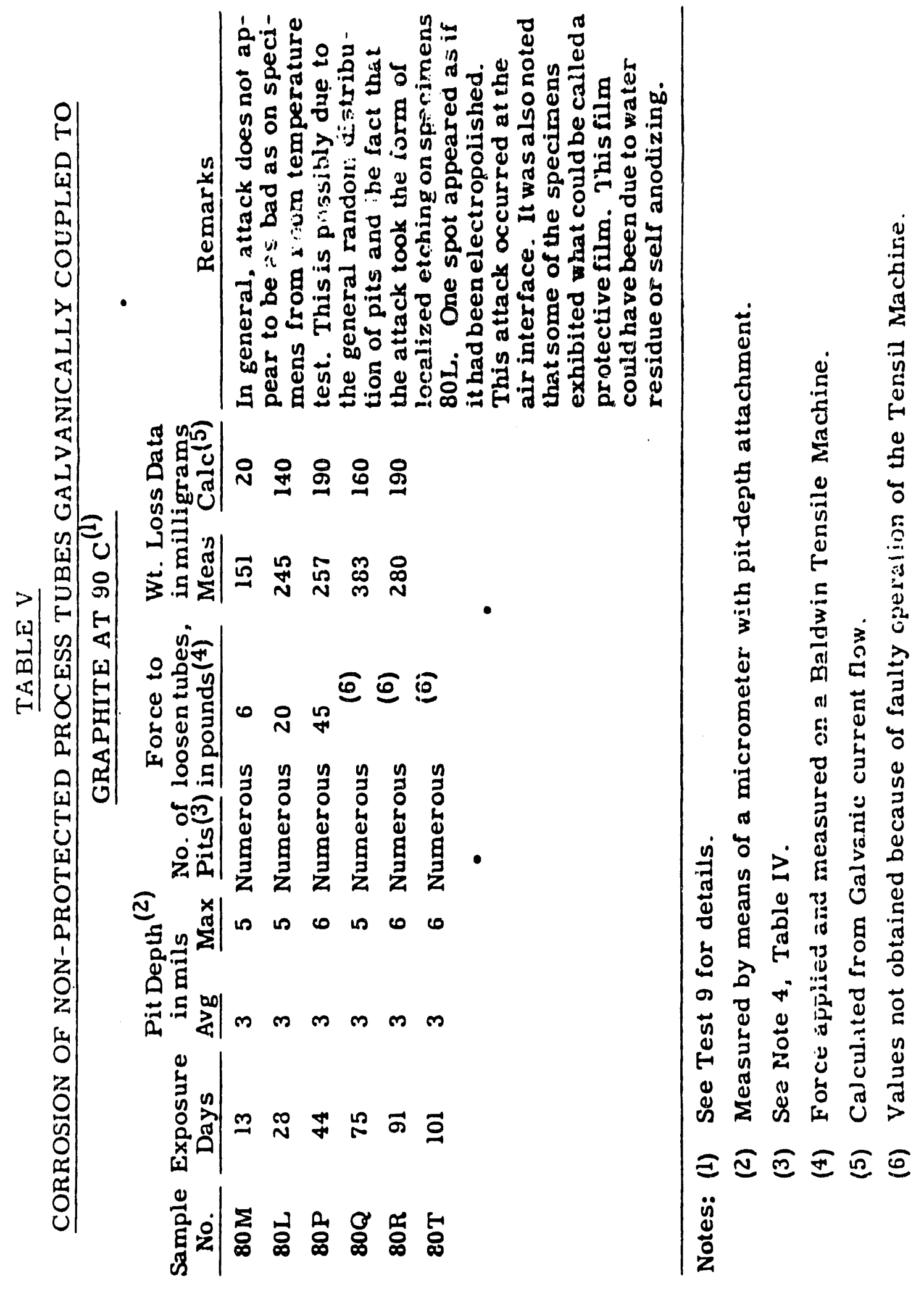




\section{DEOLASSIFIED}

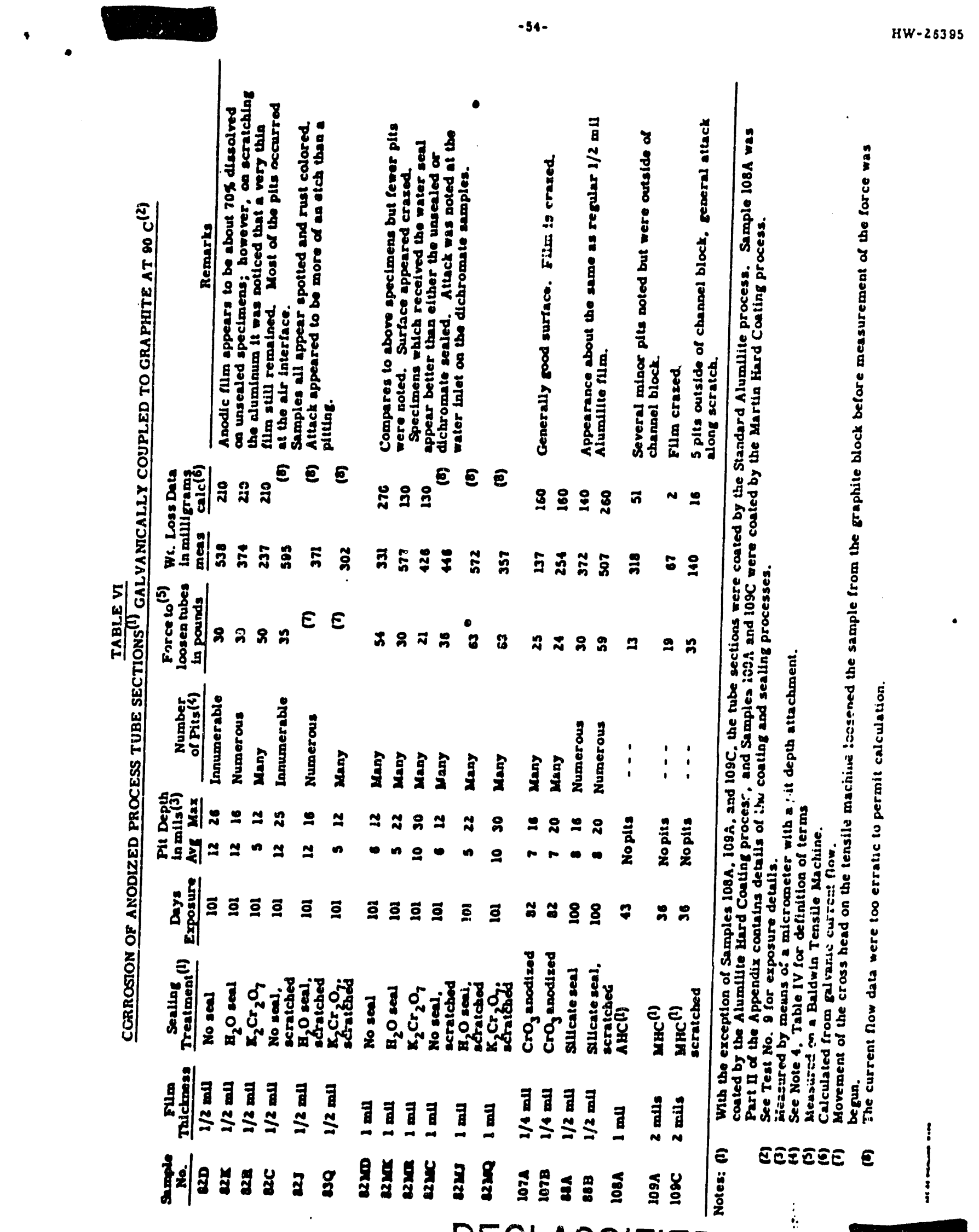

DECLASSIFIED 


\section{DECLASSIFIED}

(a) With the exception of the Alumilite Hard Coating and Martin Hard Coating samples, the anodized samples were cleaned in concentrated (70 per cent) nitric acid at room temperature. This dissolved the water-deposited salts and loosened the corrosion product to facilitate its removal. The solution had no observable effect on the anodic films.

(b) The Martin Hard Coating and Alumilite Hard Coating samples were cleaned by scrubbing in tap water using a bristle brush.

(c) The non-protected samples were stripped by immersion in the standard phosphoric acid-chromic acid solution (see Part II of the Appendix).

After weighing the cleaned samples, the Martin Hard Coating and Alumilite Hard Coating samples were partially stripped in phosphoric acid-chromic acid solution in order to determine the film thicknesses. This was done on a portion of each sample that had not been exposed to galvanic corrosion.

Results:

Table $V$ and Figures 27,28 , and 29 , contain the weight change data, pit depth measurements, current flow measurements, breaking force, and visual observations for the non-protected samples.

Table VI and Figures $30,31,32$ and 33 contain the weight change, pit depth measurements, current flow measurements, breaking force, and visual observations for the anodized samples. Photographs of the samples are contained in Figures 34 (non-protected samples), 35 (Standard Alumilite anodized samples - 1/2 mil), 36 (Standard Alumilite anodized samples - $1 \mathrm{mil}$ ), 37 (Standard Alumilite anodized samples - $1 / 2$ mil, sodium silicate sealed), 38 (Chromic Acid anodized samples - protective and decorative films). 39 (Martin Hard Coating anodized samples), and 40 (Alumilite Hard Coating anodized samples).

\section{DECLASSIFIED}


GALVANIC CURRENT FLOW FROM NON-PROTECTED PROCESS TUBE SECTIONS COUPLED TO GRAPHITE BLOCKS - 9OC

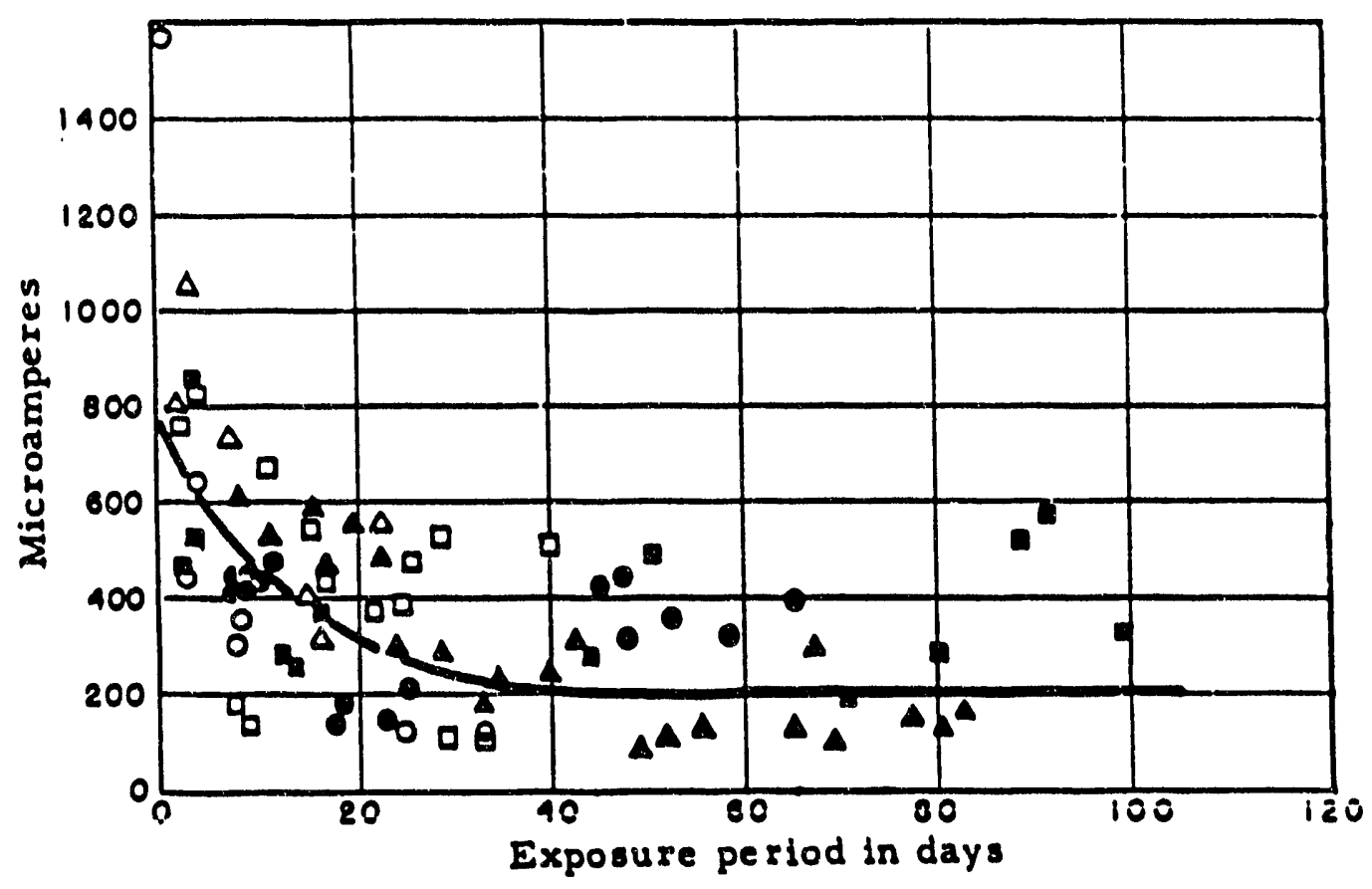

Eigure No. 27 


\section{DECLASSIFIED}

$$
-57-
$$

WEIGHT LOSS ON NON-PROTECTED PROCESS TUBE SECTIONS COUPLED TO GRAPHITE CHANNEL BLOCKS - - $90 \mathrm{C}$

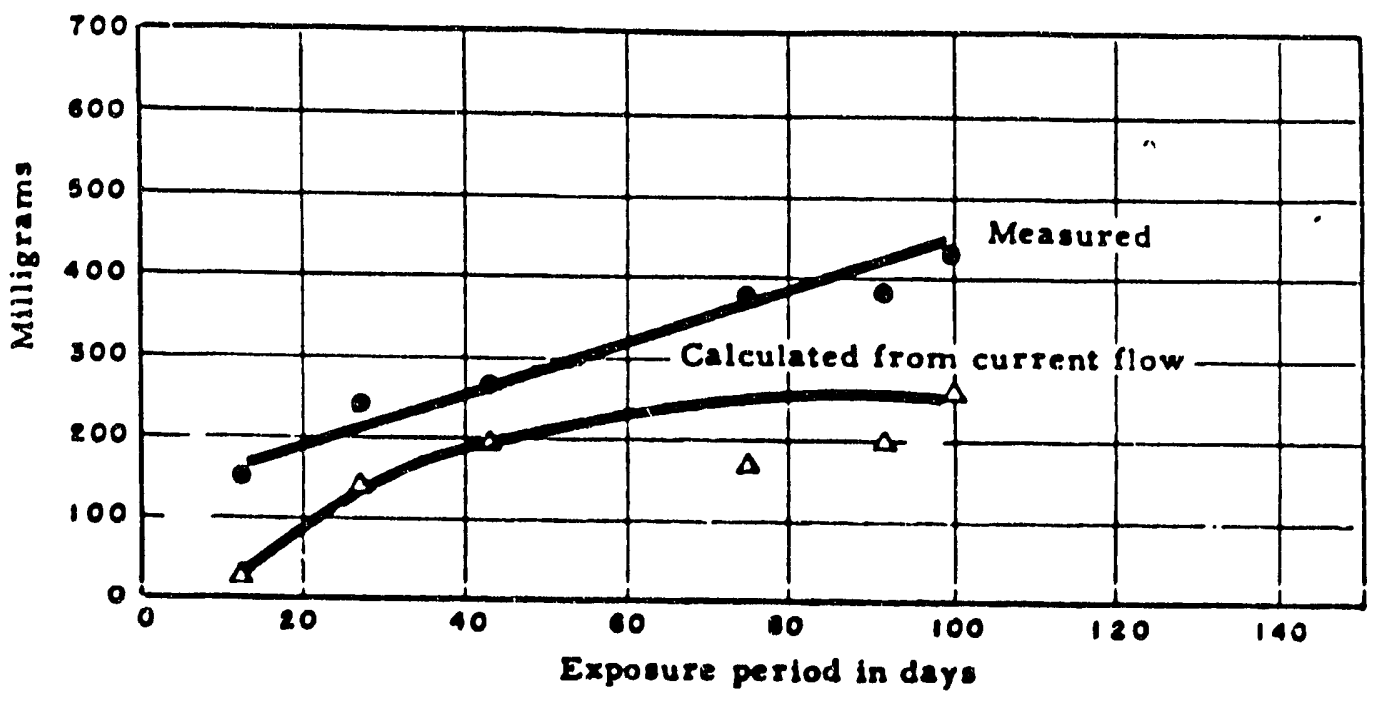

Figure No. 28

FORCE TO LOOSEN NON-PROTECTED PROCESS TUBE SECTIONS - 90C

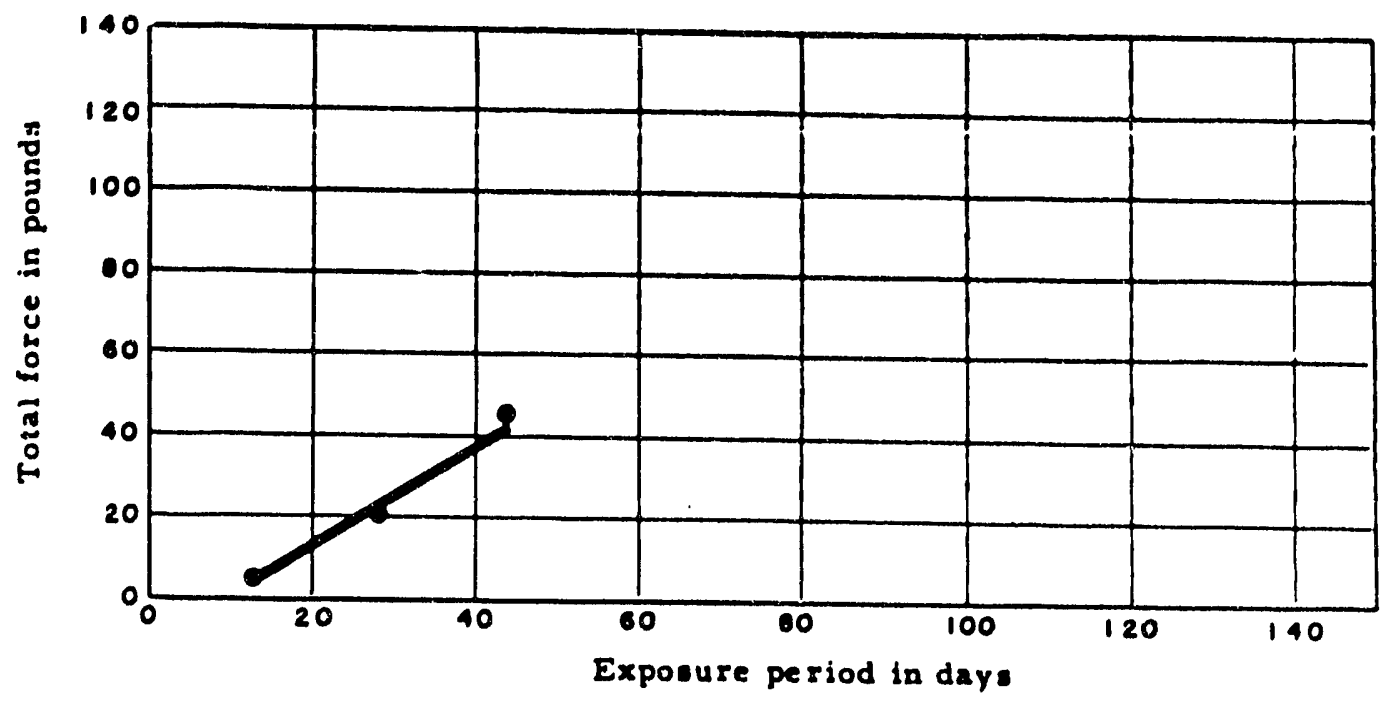

Figure Nu. 29 


\section{DECLASSIFIED}

$-98$.

Hพ-26395
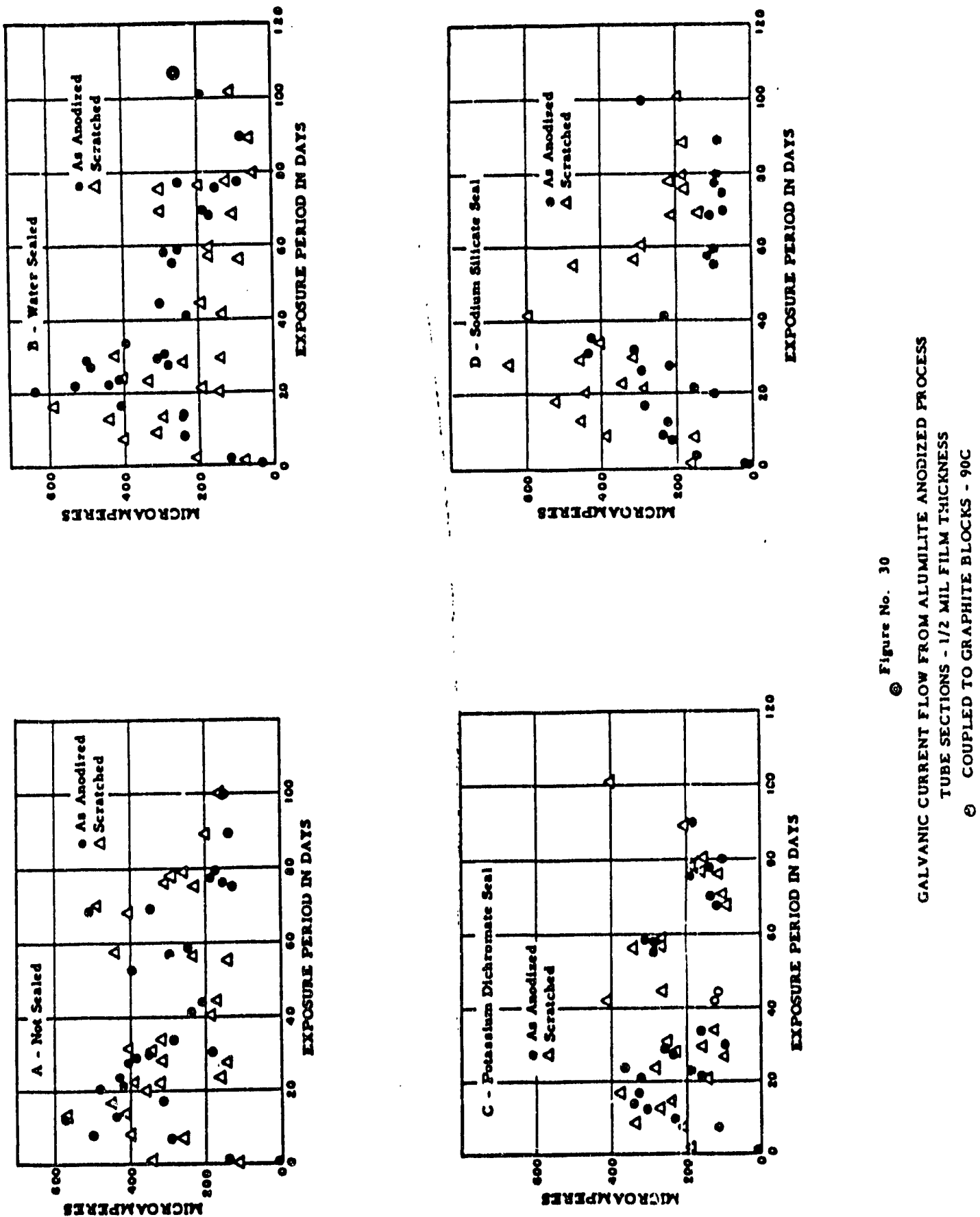

DECLASSIFIED 
GALVANIC CURRENT FLOW FROM ALUMLLITE ANODIZED PROCESS

0 TUBE SECTIONS - I MIL FILM THICKNESS - COUPLED TO GRAPHITE BLOCKS - 9OC

○
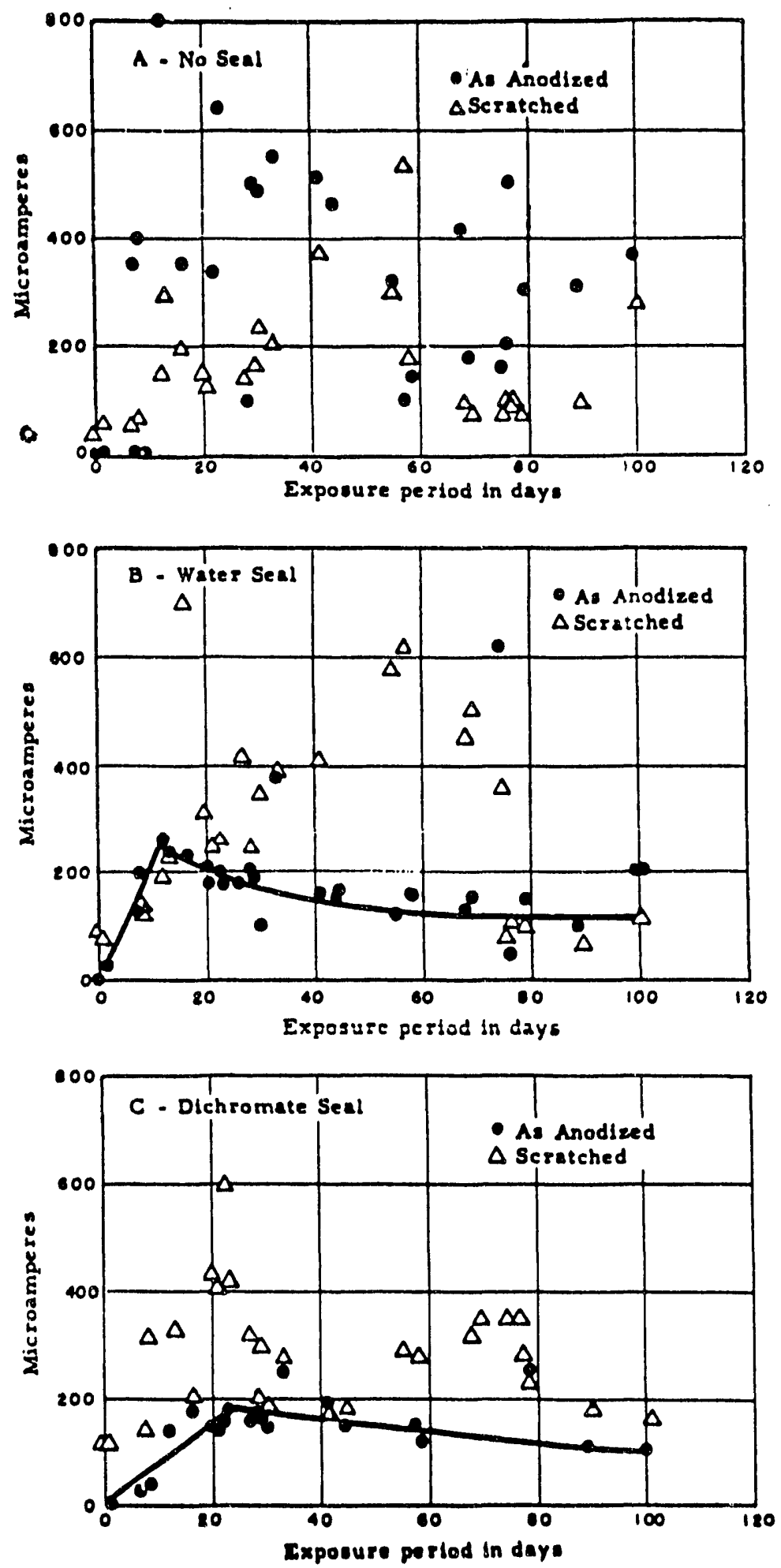

FIrure No. 31 


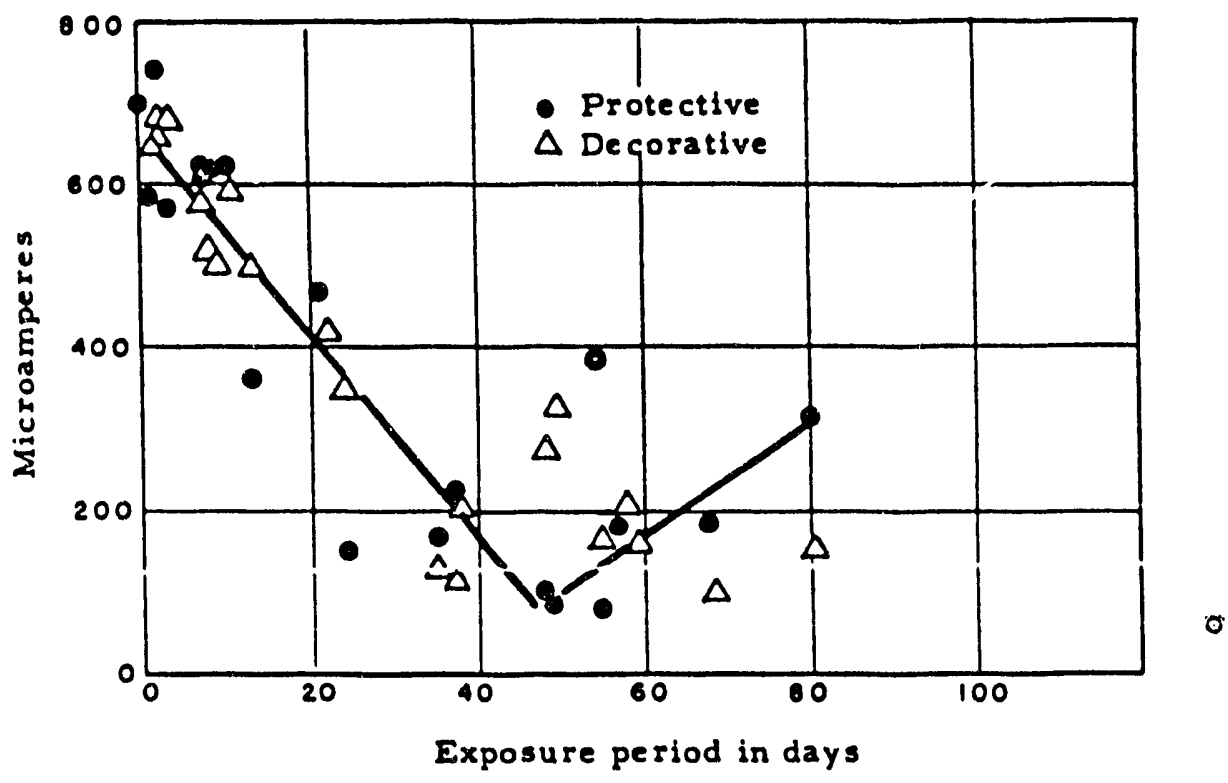

Figure No. 32

GALVANIC CURRENT FLOW BETWEEN PROCESS TUBE SECTIONS COATED WITH EITHER MARTIN HARD COATING OR ALUMILITE

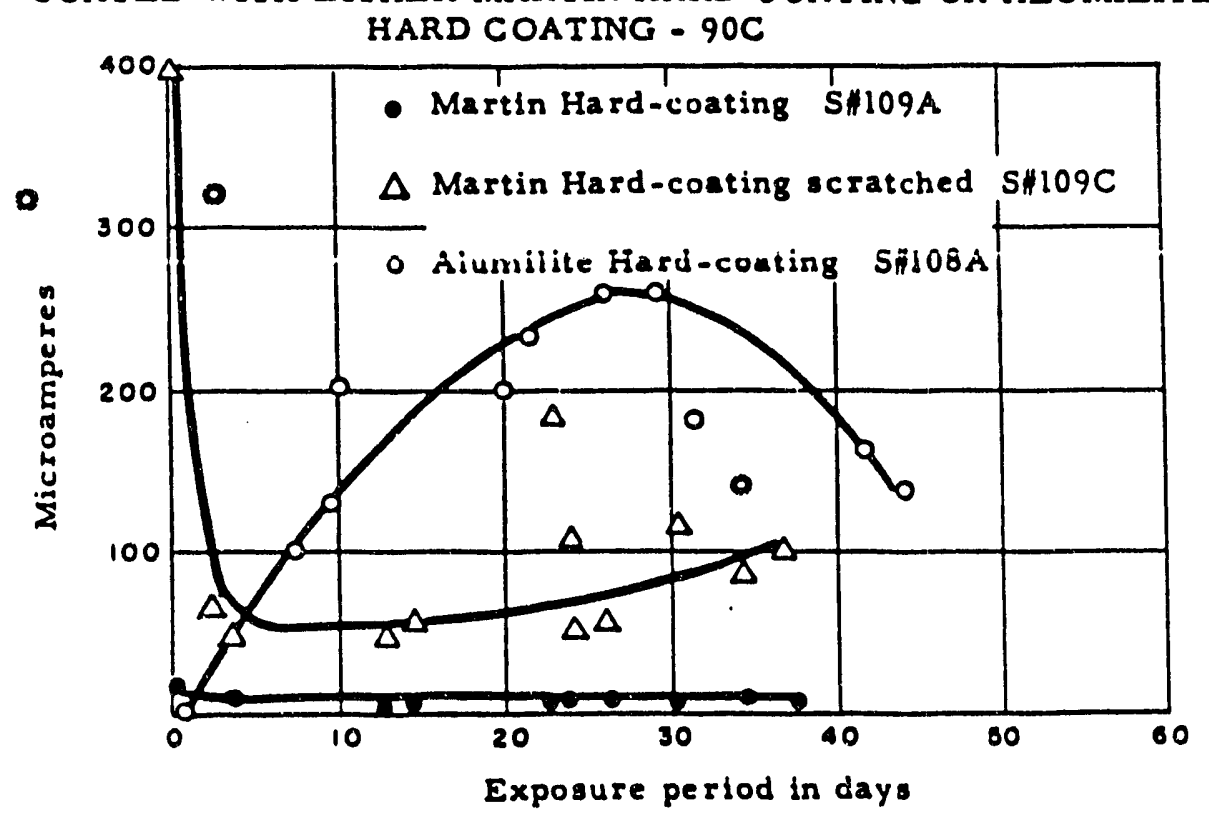

Flguro No. 33 


\section{DECLASSIFIED}

$-61-$

IIW -26395

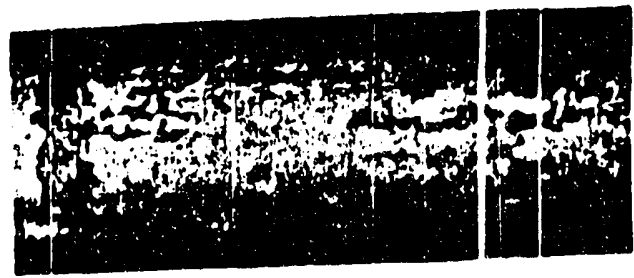

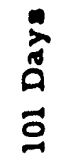

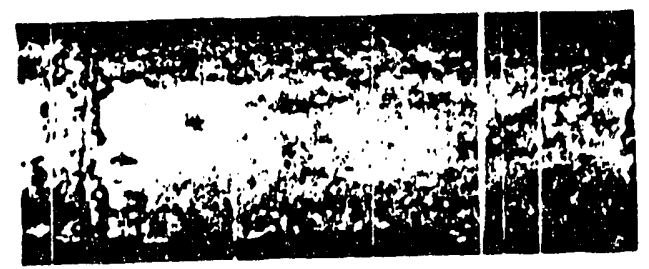

ลึ
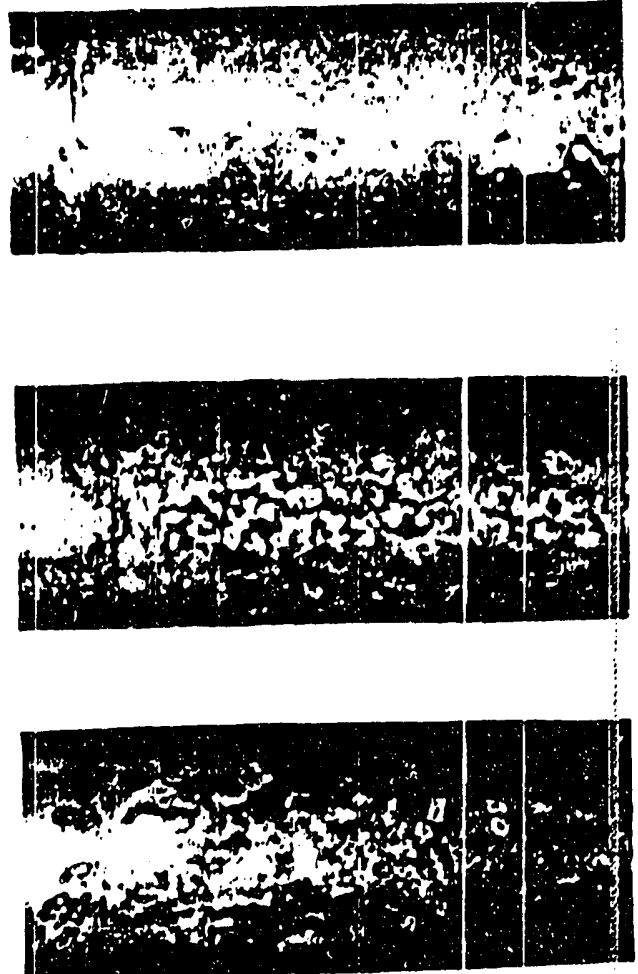

مึ

4)

क

की 4

뽀

究

$\because \stackrel{0 \omega}{\Sigma}$

zo 出

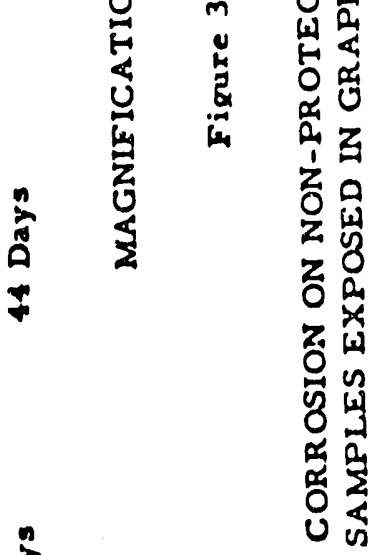

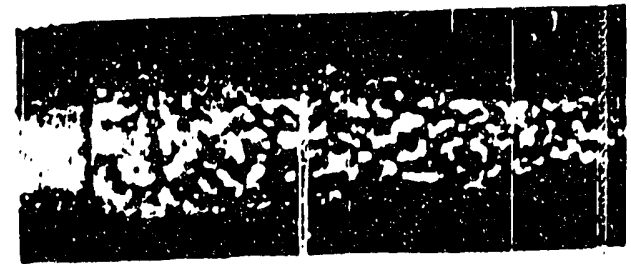

ถิ

Unclassified 


\section{DECLASSIFIED}
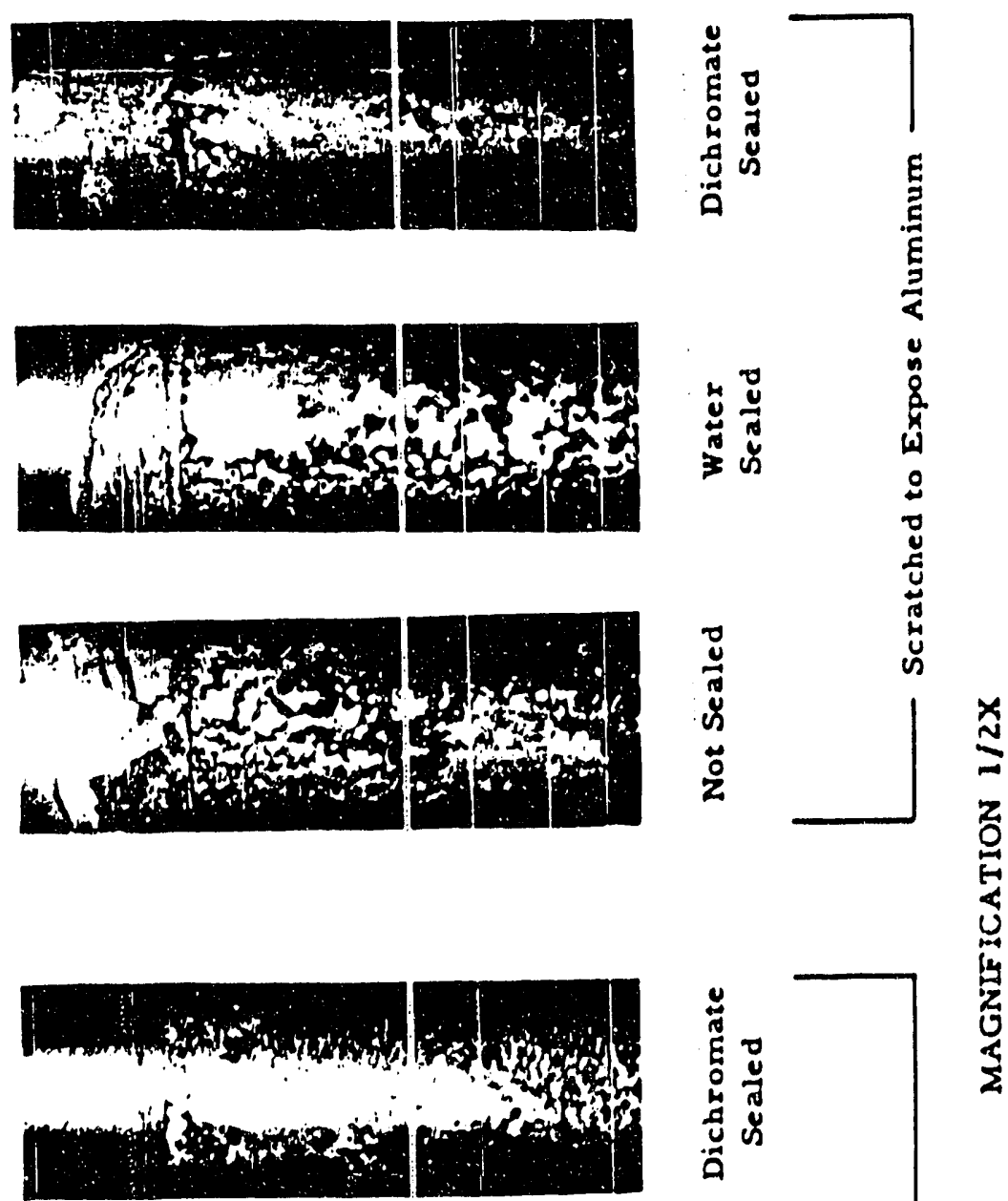

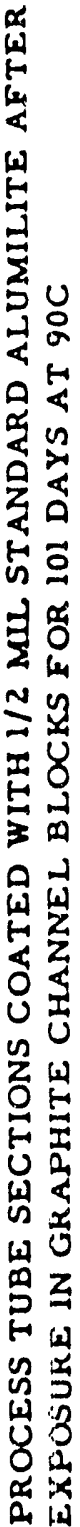

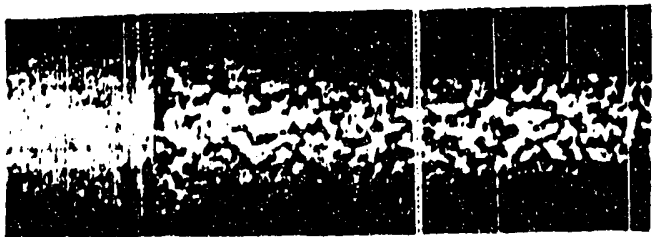

过

0
0
0

Unclassifled

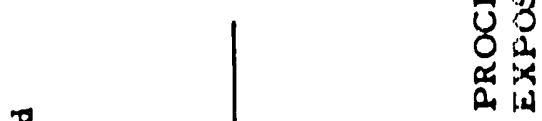

DECLASSIFIED 


\section{DECLASSIFIED}
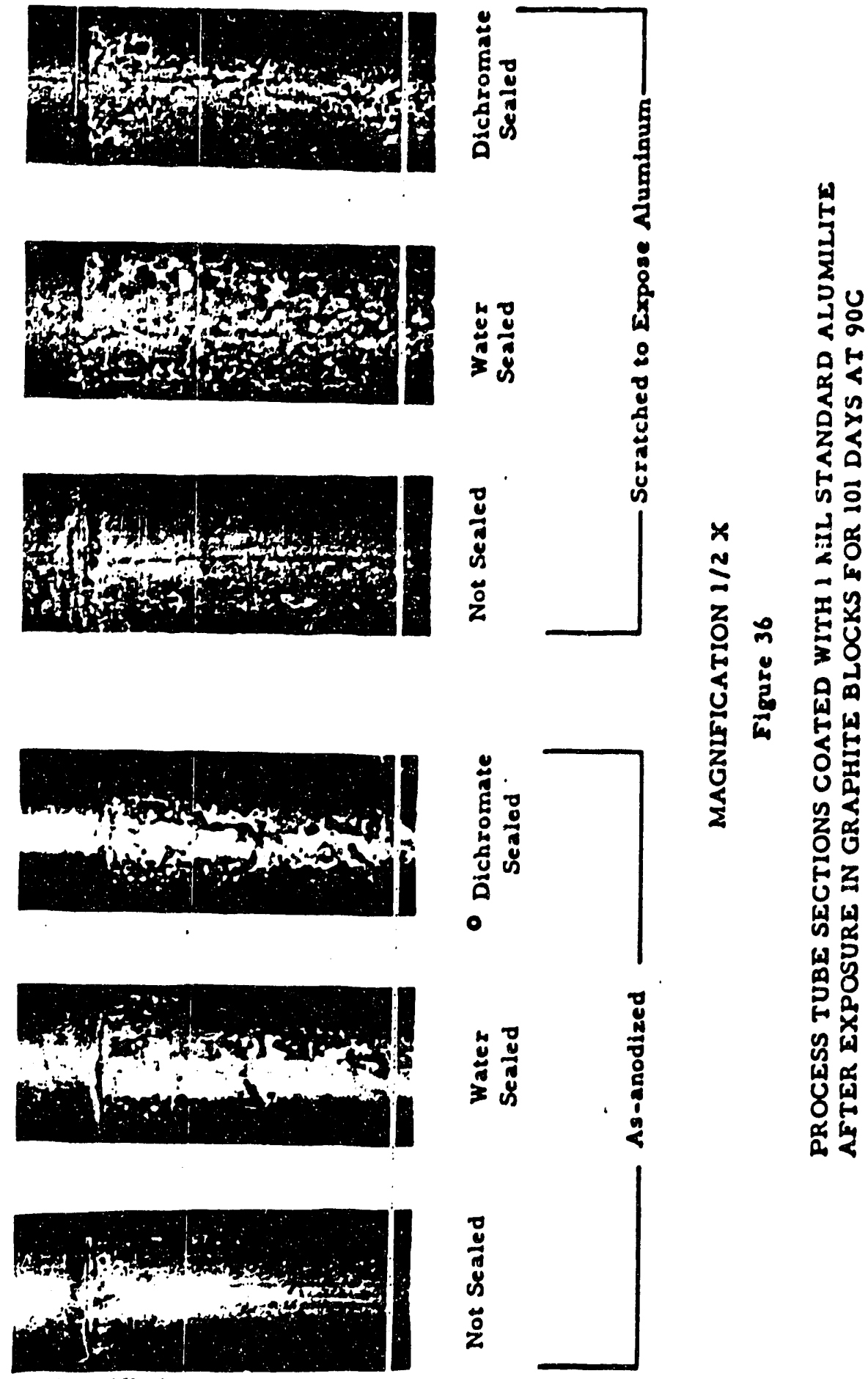

4
$y$
$y$
$y$
$y$
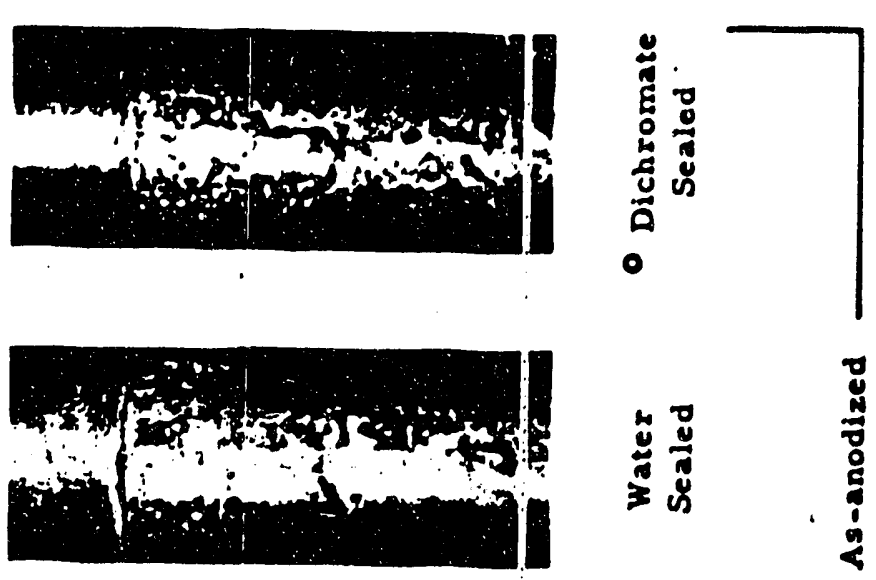

o

Unclassilled

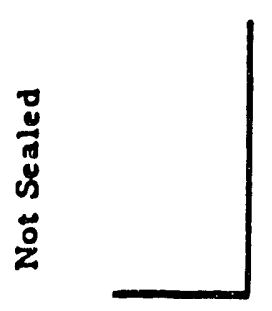

D

DECLASSIFIED 


\section{DECLASSIFIED}

$-64-$

$H W-26395$

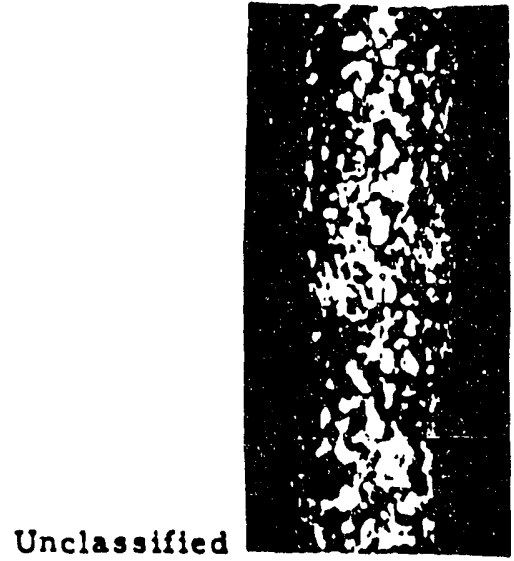

As-Anodized

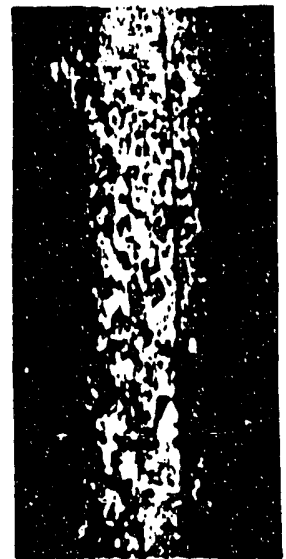

Scratched

MAGNIFICATION 6/10X

Figure 37

PROCESS TUBE SECTIONS COATED WITH $1 / 2 \mathrm{MIL}$

STANDARD ALUMILITE AND SEALED IN SODIUM

- SILICATE AFTER EXPOSURE IN GRAPHITE BLOCKS

FOR 100 DAYS AT $90 \mathrm{C}$

$\odot$
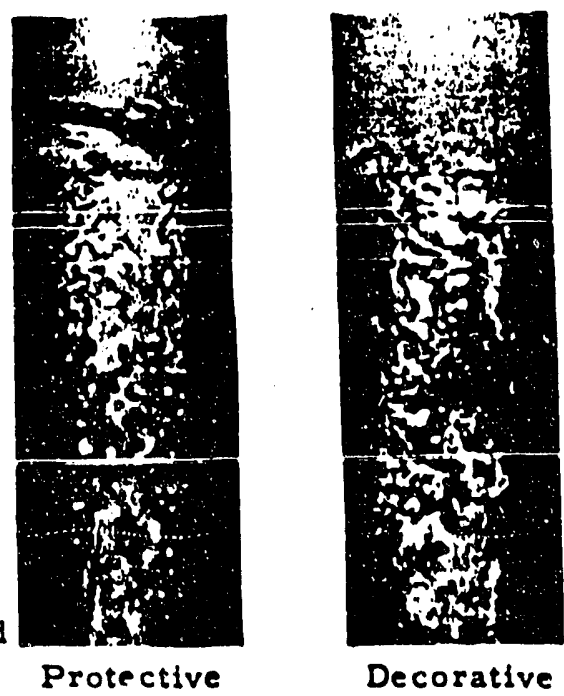

$\circ$

MAGNIFICATION $1 / 2 \mathrm{X}$

Figure 38

SAMPLES OF PROCESS TUBING COATED WITH $1 / 4 \mathrm{MIL}$ CHROMIC ACID ANODIC FILMS AFTER EXPOSURE IN

GRAPHITE. CHANNEL BLOCKS FOR 8? DAYS AT 9OC 


\section{DECLASSIFIED}

.65 -

HW -26395

-

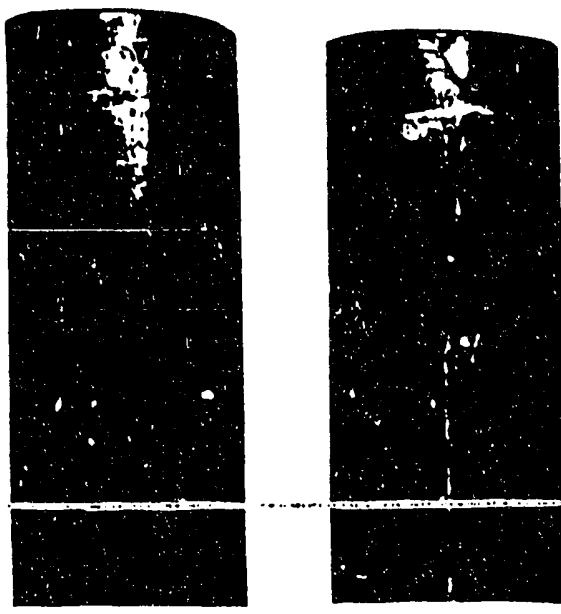

FIGURE 39

PROCESS TUBE SECTIONS COATED WITH 2 MILS MARTIN HARD COATING AFTER EXPOSURE IN GRAPHITE CHANNEL BLOCKS FOR 36 DAYS AT 90C. SAMPLE ON RIGHT HAS BEEN SCRATCHED TO EXPOSE ALUMINUM.

MAGNIFICATION $4 / 10 \times$

Unclassifle de

(๑)

(1)

FIGURE 40

PROCESS TUBE SECTION COATED WITH I MIL ALUMILITE HARD COATING AFTER EXPOSURE IN A GRAPHITE CHANNEL BLOCK FOR 43 DAYS AT $90 \mathrm{C}$.

MAGNIFICATION $4 / 10 \mathrm{X}$ 


\section{DECLASSIFIED}

Test 10: Aluminum - Graphite Galvanic Couple Test at $85 \mathrm{C}$ Description:

Samples of process tubing coated with Martin Hard Coating ( $2 \mathrm{mils}$ ), Alumilite Hard Coating $(2 \mathrm{mils})$, and Standard Alumilite $(1 \mathrm{mil})$ were heated in a furnace at $200 \mathrm{C}$ for 2 weeks. Following the heating cycle, these samples, and similarly coated non-heated samples, were inserted within graphite channel blocks and electrically connected to the blocks through $10 \mathrm{ohm}$ resistors. The block assemblies were then immersed to within $1 / 4$ incin oi the top suriace in a tank of flowing pile-filtered water from 105-B water supply) maintained at $85 \mathrm{C}$. The block and tube assemblies were electrically insulated from the tank by means of Micarta strips. The flow rate of the water surrounding the samples was very low. The blocks contained three drilled holes on each face to allow the passage of water into the annulus between the process tube and the channel block. Figure 41 depicts the block and tube assembly. Figure 42 depicts the test units within the trough of nowing hot water. The meter at the right hand side of the picture is a vacuum-tube voltmeter employed in corrosion current measurements. The period of the test was 10 days.

Results:

Galvanic couple current flow messurements, pit depth and number of pits: and the force required to loosen the tube scctions are cuntailieu in Table VII and Figure 43. Figures 44, 45, 46, and 47 are photographs of the non-coated and the anodized tube sections after galvanic corrosion, but prior to removal of the anodic film for pit depth measurements. 


\section{DECLASSIFIED}

.67.

HW -26395
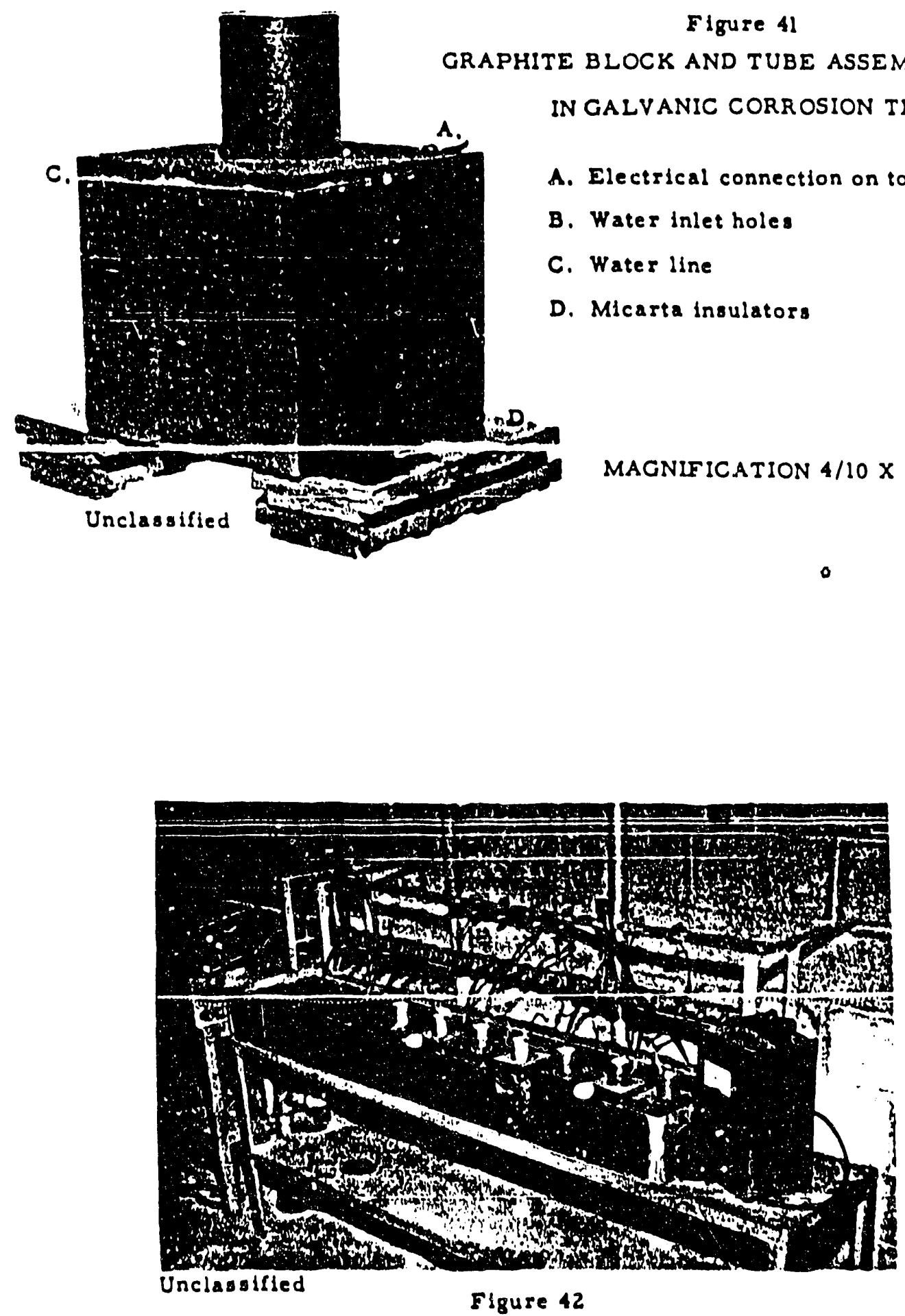

CORROYION TEST CELLS PARTIALLY IMMERSED IN HOT WATER

DECLASSIFED 


\section{DECLASSIFIED}
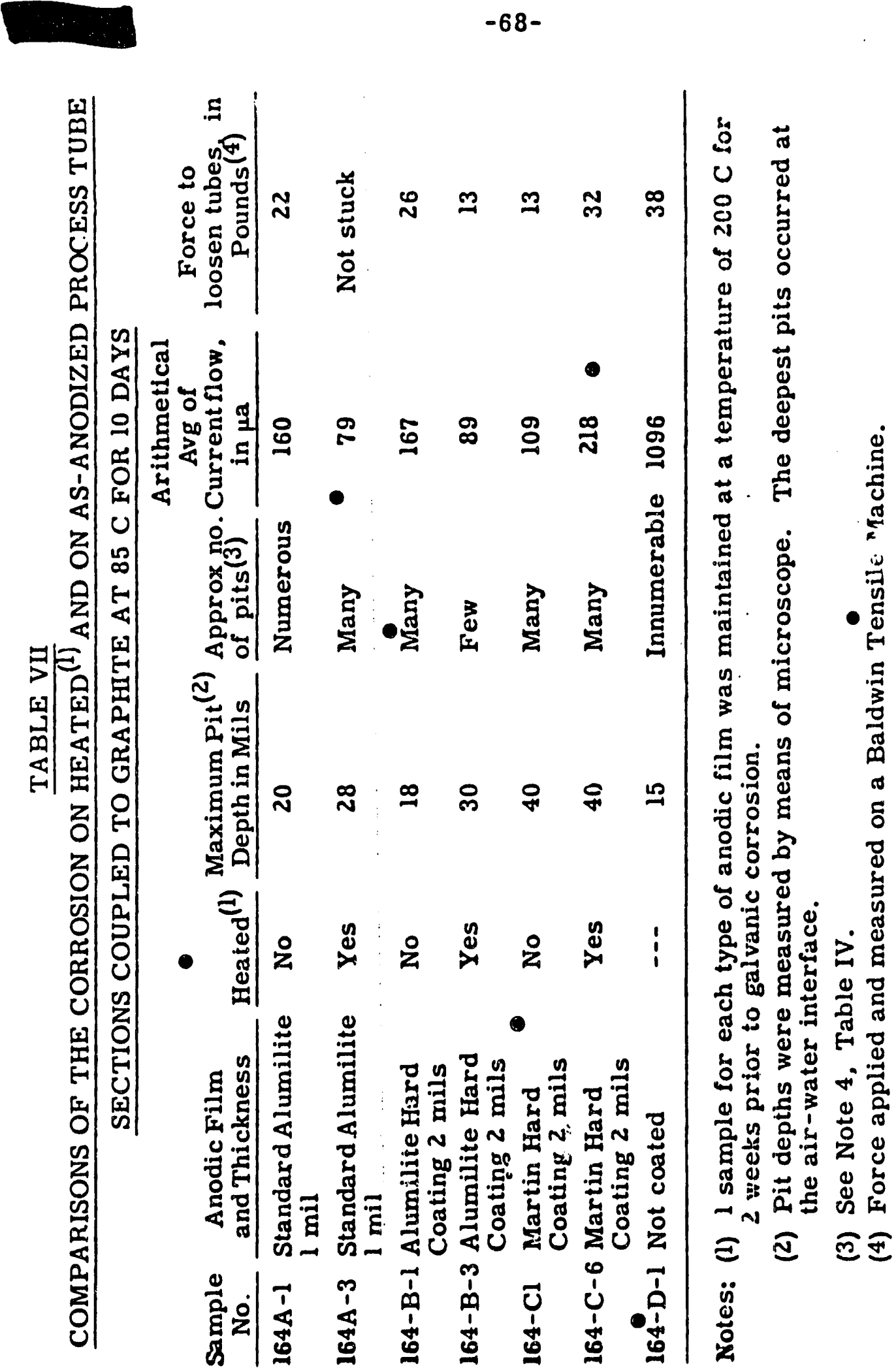


\section{DECLASSIFIED}

$-69$.

GALVANIC COUPLE CORROSION TEST OT NON-COATED AND ANODIZED PROCESS TUBE SECTIONS AT $85 \mathrm{C}$
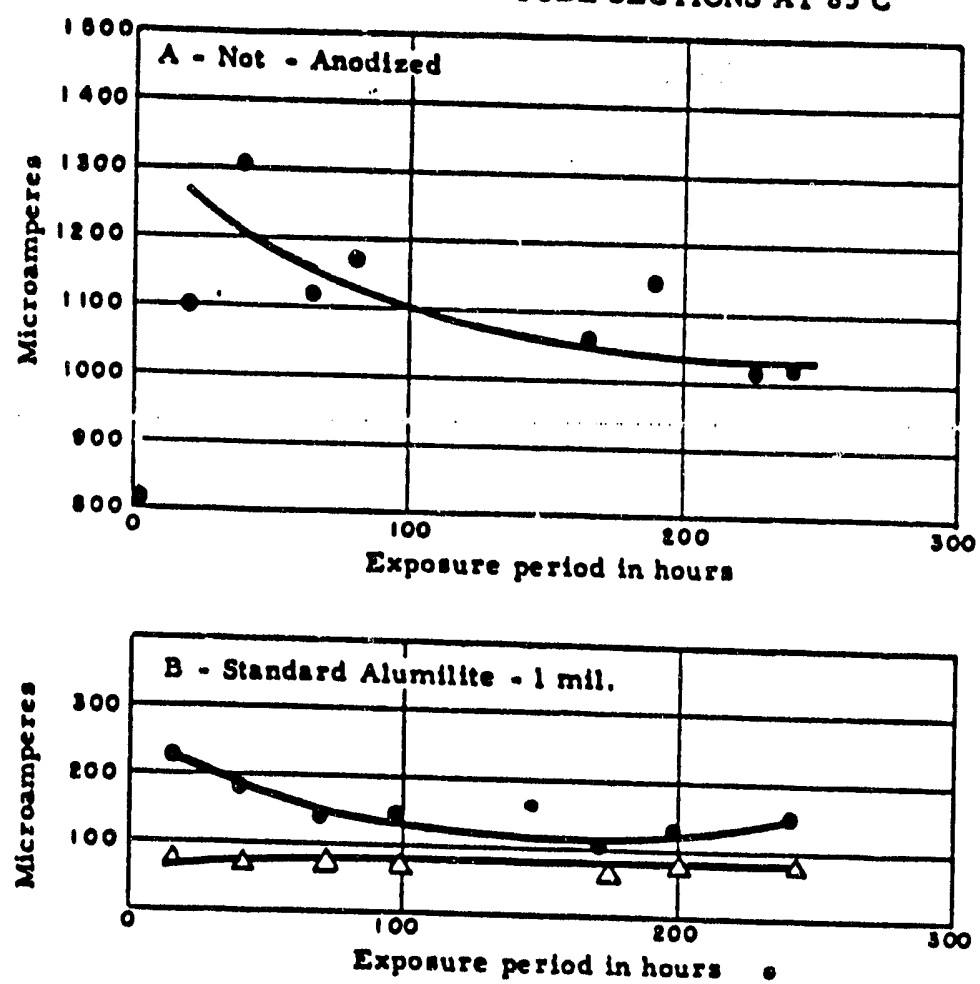

(Samples marked $A$ were heated to 200 c for 2 weeke prlor so teating samples masked (P) were not heated).

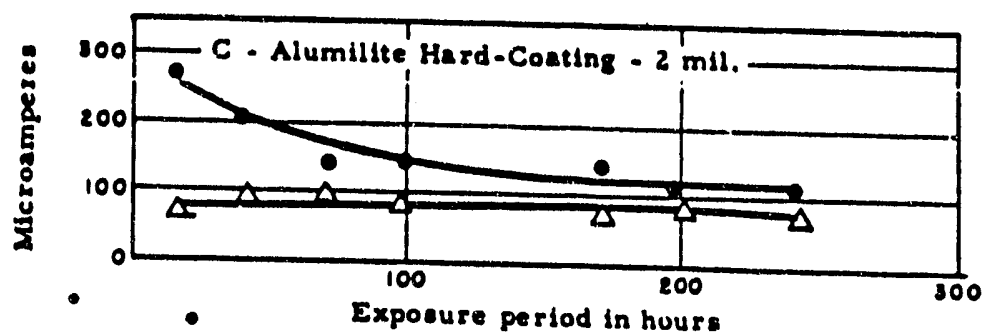

$\bullet$

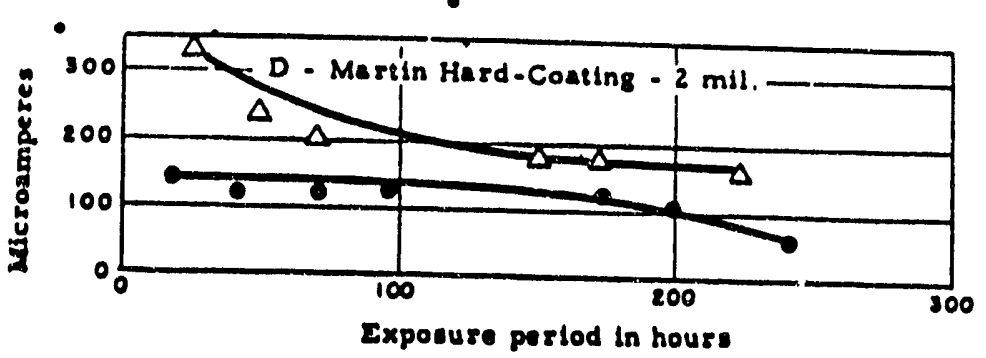

Figure No. 43 


\section{DECLASSIFIED}

FIGURE 44

NON-PROTECTED PROCESS TUBE SECTION AFTER EXPOSURE IN A WET GRAPHITE CHANNEL BLOCK FOR 10 DAYS AT 85C.

MAGNIFICATION $4 / 10 \times$

Unclassified
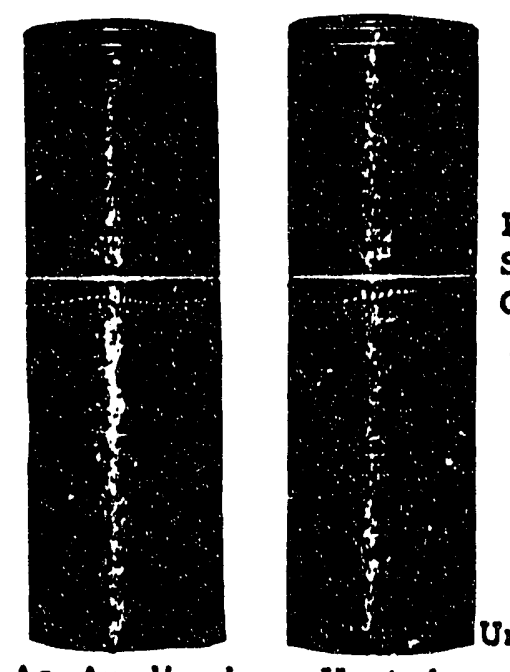

PROCESS TUBE SECTIONS COATED WITH 1 MIL
STANDARD ALUMILITE AFTER EXPOSURE IN WET
GRAPHITE CHANNEL BLOCKS FOR 10 DAYS AT $85 C$

PROCESS TUBE SECTIONS COATED WITH 1 MPL
STANDARD ALUMILITE AFTER EXPOSURE IN WET
GRAPHITE CHANNEL BLOCKS FOR 10 DAYS AT $85 C$

PROCESS TUBE SECTIONS COATED WITH I MIL
STANDARD ALUMILITE AFTER EXPOSURE IN WET
GRAPHITE CHANNEL BLOCKS EOR 10 DAYS AT $85 C$ MAGNIFICATION 4/10X

As-Anodlzed

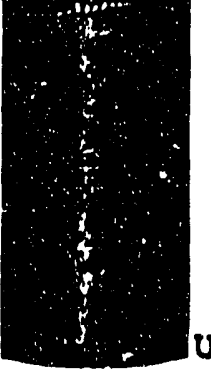

Heated to $200 \mathrm{C}$

FIGURE 45

\section{DECLASSIFIED}




\section{DECLASSIFIED \\ -71 .}
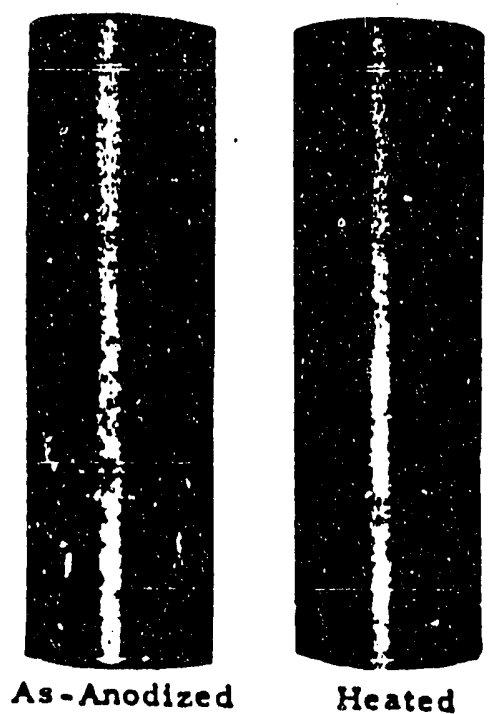

Heated

to $200 \mathrm{C}$

FIGURE 46

PROCESS TUBE SECTIONS COATED WITH 2 MILS OF MARTIN HARD COATING AFTER EXPOSURE IN WET GRAPHITE CHANNEL BLOCKS FOR 10 DAYS AT 85C.

\section{MAGNIFICATION $4 / 10$}

\section{Unclassified}
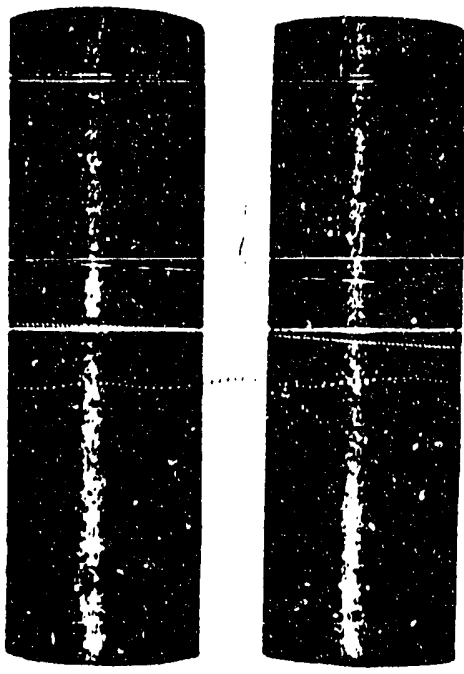

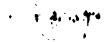

\section{FIGURE 47}

PROCESS IUBE SECTIONS COATED WITH 2 MILS OF ALUMILITE HARD COATING AFTER EXPOSURE IN WET CIRAPHITE CHANNEL BLOCKS FOR 10 DAYS AT 85C.

MAGNIFICATION 4/10

Unclassifled

Heated to $200 \mathrm{C}$

MACNLICATION $4 / 10$

As-Anodized

$$
\text { to } 200 \mathrm{C}
$$

\section{DECLASSIFIED}




\section{DECLASSIFIED}

APPENDIX

Partil: Coating Procedures

In general commercial practice was employed for the application of the various coatings tested. Variations from standard practice will be noted in the text.

\section{ANODIC COATINGS}

\section{Standard Alumilite}

Cleaning: The pieces to be coated were degreased in an inhibited alkaline cleaner to a water break-free surface condition, then rinsed in cold runsing tap water.

Electrolyte: The electrolyte contained 15 per cent sulfuric acid by weight. The concentration was measured periodically by means of a hydrometer. Agitation: To insure adequate agitation, two mechanical stirrers were employed.

○

Operating Conditions:

Current Density: 12 amperes per square foot

Temperature: $\quad 60 \mathrm{~F}$ to $70 \mathrm{~F}$

Time:

17 minutes for $1 / 4 \mathrm{mil}$ film

33 minutes for $1 / 2 \mathrm{mil}$ film

65 minutes for $1 \mathrm{mil} f i \mathrm{~m}$

Rinsing: The samples were rinsed for 20 minutes in cold running water to remove entrapped or adsorbed electrolyte.

Sealing Treatments: See page 75 of Part II of the Appendix.

2. Alumilite Hard Coating

Cleaning: The pieces to be coated were degreased in an inhibited alkaline cleaner to produce a water break-free surface condition, then rinsed in sold running water.

\section{DECLASSIFIED}




\section{DECLASSIFIED}

Electrolyte: The electrolyte contained 12 per cent sulfuric acid and 1 per cent oxalic acid, both percentages by weight.

Agitation: To insure adequate agitation, two mechanical stirrers were employed.

Temperature: The temperature was maintained at $50 \mathrm{~F} \pm 2 \mathrm{~F}$ by means of cooling coils cast into the lead lining of the tank.

Operating Conditions:

Current Density: 36 amperes per square foot

Temperature: $\quad 50 \mathrm{~F} \pm 2 \mathrm{~F}$

Time:

20 minutes for $1 \mathrm{mil}$

Rinsing: The samples were rinsed for 20 minutes in cold running water to remove entrapped or adsorbed electrolyte.

Sealing Treatment: None employed.

3. Martin Hard Coating

Cleaning: The pieces were degreased in an inhibited alkaline cleaner to a water break-free surface condition, then bright-etched in the following solution:

Nitric acid (70 per cent)

$25 \mathrm{cc}$

Hydrofluoric Acid (48 per cent)

$5 \mathrm{cc}$

$\infty$

Ammonium Hydroxide (28 per cent) $13 \mathrm{cc}$

Glycerine

$5 \mathrm{cc}$

Chromic Acid Anhydride

2 grams

Water to make one liter

The etch time was 10 minutes at $190 \mathrm{~F}$.

Electrolyte: The electrolyte contained 15 per cent sulfaric acid by weight. Prior to use, the electrolyte was saturated with carbon dioxide. During anodizing, carbon dioxide was bubbled through the solution.

○

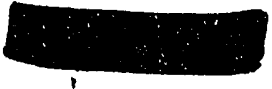


Agitation: To insure adequate agitation, two mechanical stirrers were employed.

Operating Conditions:

Current Density: 25 amperes per square foot

Temperature: $25 \mathrm{~F}$ to $32 \mathrm{~F}$

Time: $\quad 30$ minutes for $1 \mathrm{mil}$

Rinsing: The samples were rinsed for 20 minutes in cold running water to remove entrapped or adsorbed electrolyte.

Sealing Treatment: None employed.

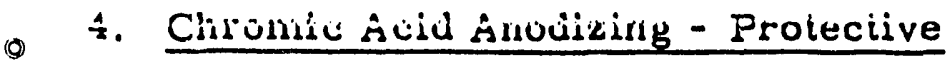

Cleaning: The pieces to be anodized were degreased in an inhibited alkaline cleaner to a water break-free surface condition, then rinsed in cold running water.

-

Electrolyte: The electrolyte contained 3 per cent chromic acid byoweight.

Agitation: To insure adequate agitation, two mechanical stirrers were employed.

Operating Conditions:

Current Density: 3 amperes per square foot (41 volts)

Temperature: $\quad 100 \mathrm{~F} \pm 5 \mathrm{~F}$

Time: 75 minutes for $1 / 4 \mathrm{mil} \mathrm{film}$

Rinsing: The samples were given a quick rinse in cold running tap water, then dried.

5. Chromic Acid Anodizing - Decorative

Cleaning: The pieces to be anodized were degreased in an inhibited alkaline cleaner to a water break-free surface condition, then rinsed in cold running water.

\section{DECLASSIFIED}




\section{DECLASSIFIED}

Electrolyte: The electrolyte contained 5 per cent chromic acid by weight. Agitation: To insure adequate agitation, two mechanical stirrers were employed.

Operating Conditions:

Current Density: Approx. 8 amperes per square foot (66 volts)

Temperature: $\quad 120 \mathrm{~F} \pm 5 \mathrm{~F}$

Time: 45 minutes for $1 / 4 \mathrm{mil}$

Rinsing: The samples were given a quick rinse in cold running water and then dried.

○

Sealing: Not employed.

SEALING TREATMENTS

The following sealing treatments were employed in conjunction with the anodic films. The methods reflect commercial practice as presented in the Alcoa Bulletin, "Instructions for Applying Alumilite Finishes, " published in P949.

Water Seal:

After anodizing, the samples were immersed in boiling de-ionized water for 30 minutes. They were then allowed to air-dry.

Dichromate Seal:

After anodizing, the samples were immersed for 30 minutes in a boiling solution of potassium dichromate, 5 per cent by weight, at a pH of 6.5 .

\section{Sodium Silicate Seal:}

After anodizing, the sarnples were immersed at room temperature in a. water solution containing sodium sillcate, 50 per cent by volume, for 5 minutes. This was followed by a 10 minute drying period at $100 \mathrm{C}$. 


\section{DECLASSIFIED}

\section{DE-ANODIZING}

Removal from aluminum of anodic films and of most aluminum corrosion products was accomplished by immersing the aluminum sample for 10 minutes at $190 \mathrm{~F}$ in a water solution contiining 2 per cent by weight chromic acid and 5 per cent by weight phosphoric acid. Martin Hardcoating and Alumilite Hardcoating may require longer immersion to remove the anodic film completely.

\section{(}




\section{ABSTRACT}

Corrosion on the exterior of process tubes, resulting from contact with molst graphite, has been a serious problem in the operation of one of the Hanford Reactors. The severity of corrusive attack increased with increasing exposure, and the resulting corrosion product causer many of the process tubes to stick in the graphite channels.

A laboratory investigation was initiated to determine the mechanism of corrosion on the t:abe exteriors and to evaluate anodic films r.j barriers to the observed corrusion.

Electrode potential measurements between aluminum and graphite demonstrated the existence of a large voltage drop between these materials, 0.58 volts at $20 \mathrm{C}$ and 1.22 volts at $77 \mathrm{C}$. This voltage drop suggested an electrochemical explanation of the in-plle corrosion. Galvanic current flow measurements from sections of process tubing contained in, and electrically coupled to, moist graphite confirmed the electrochemical nature of the attack.

Anodic films were applied to sections of process tubing by the Alumilite process, the Martin Hard Coating process and Alumilite Hard Coating process. Films applied by the Alumilite process were tested at room temperature and at $90 \mathrm{C}$ in three thicknesses $(1 / 4,1 / 2$ and $1 \mathrm{mil})$ and with three sealing treatments (unsealed, water sealed, and dichromate sealed). The samples ccated by the Martin Hard Coating process and Alumilite Hard Coating process had a two mil film and were tested at $90 \mathrm{C}$. The coatings were evaluted by comparison with non-cuuled samples.

Anodizing was effective in reducing the severity of galvanic corrosion provided that the anodic films were at least 1 mil thick. Sealing of the Alumilite anodic films in water and/or sodium dichromate solution increased their effectiveness.

Heating of the anodic films to $200 \mathrm{C}$ for 2 weeks had a variable initial effect on the protective value of the anodic films. The difference between the protective value of heated and non-heated anodic films decreased with increasing exposure to galvanic corrosion.

\section{DECLASSIFIED}



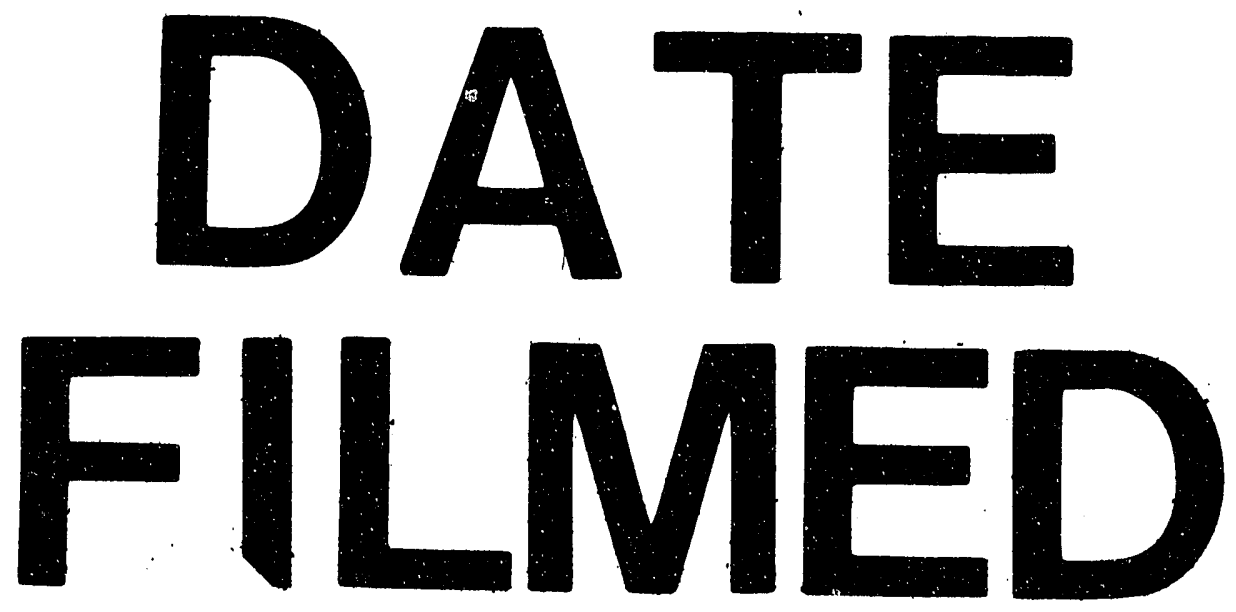

01108193 


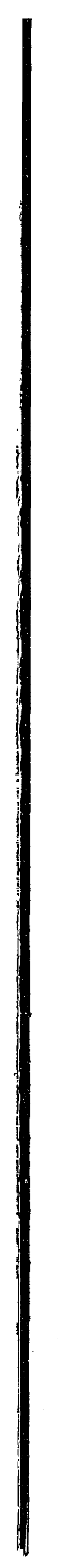

